\title{
Quaternary disappearance of tree taxa from Southern Europe: timing and trends
}

DOI:

10.1016/j.quascirev.2017.02.014

\section{Document Version}

Accepted author manuscript

Link to publication record in Manchester Research Explorer

\section{Citation for published version (APA):}

Magri, D., Di Rita, F., Arabarri Erkiaga, J., Fletcher, W., \& González Sampériz, P. (2017). Quaternary disappearance of tree taxa from Southern Europe: timing and trends. Quaternary Science Reviews, 163, $23-55$. https://doi.org/10.1016/j.quascirev.2017.02.014

\section{Published in:}

Quaternary Science Reviews

\section{Citing this paper}

Please note that where the full-text provided on Manchester Research Explorer is the Author Accepted Manuscript or Proof version this may differ from the final Published version. If citing, it is advised that you check and use the publisher's definitive version.

\section{General rights}

Copyright and moral rights for the publications made accessible in the Research Explorer are retained by the authors and/or other copyright owners and it is a condition of accessing publications that users recognise and abide by the legal requirements associated with these rights.

\section{Takedown policy}

If you believe that this document breaches copyright please refer to the University of Manchester's Takedown Procedures [http://man.ac.uk/04Y6Bo] or contact uml.scholarlycommunications@manchester.ac.uk providing relevant details, so we can investigate your claim.

\section{OPEN ACCESS}




\title{
Manuscript Details
}

\section{Manuscript number}

Title

Article type
JQSR_2016_62

Quaternary disappearance of tree taxa from Southern Europe: timing and trends

Invited review article

\begin{abstract}
A hundred pollen and macrofossil records over the Iberian Peninsula, Southern France, the Italian Peninsula, Greece and the Aegean, and the southwestern Black Sea area have formed the basis for a review on the Quaternary extirpation of tree populations from Southern Europe. Following a discussion of the caveats/challenges about using pollen data, the Quaternary history of tree taxa has been reconstructed with attention to Taxodium/Glyptostrobus, Sciadopitys, Cathaya, Cedrus, Tsuga, Eucommia, Engelhardia, Carya, Pterocarya, Parrotia, Liquidambar, and Zelkova. The timing of extinction, distributed over the whole Quaternary, appears very diverse from one region to the other, in agreement with current biodiversity in Southern Europe. The geographical patterns of persistence/ disappearance of taxa show unexpected trends and rule out a simple North to South and/or West to East trend in extirpations. In particular, it was possible to detect disjunct populations (Engelhardia), long-term persistence of taxa in restricted regions (Sciadopitys), distinct populations/species/genera in different geographical areas (Taxodium type). Some taxa that are still widespread in Europe have undergone extirpation in Mediterranean areas in the lateglacial period and Holocene (Buxus, Carpinus betulus, Picea); they provide indication on the modes of disappearance of tree populations that may be useful to evaluate correctly the vulnerability of modern fragmented plant populations. The demographic histories of tree taxa obtained by combined palaeobotanical and genetic studies is a most challenging field of research not only to assess species/population differentiation, but also to reach a better understanding of extinction processes, an essential task in the current global change scenario.
\end{abstract}

Keywords

Corresponding Author

Corresponding Author's Institution

Order of Authors

Suggested reviewers
Quaternary; Southern Europe; vegetation dynamics; Taxodium-type; Sciadopitys; Cathaya; Cedrus; Tsuga; Eucommia; Engelhardia; Carya; Pterocarya; Parrotia; Liquidambar; Zelkova

Donatella Magri

Sapienza University

Donatella Magri, Federico Di Rita, Josu Aranbarri Erkiaga, William Fletcher, Penélope González Sampériz

Chronis Tzedakis, Adele Bertini, Suzanne Leroy, Demet Biltekin 


\section{Submission Files Included in this PDF}

\section{File Name [File Type]}

Magri et al_cover letter.docx [Cover Letter]

Magri et al_Quaternary disappearance.docx [Manuscript File]

Magri et al_Quaternary disappearance_Fig 1.jpg [Figure]

Magri et al_Quaternary disappearance_Fig 2.jpg [Figure]

Magri et al_Quaternary disappearance_Fig 3.jpg [Figure]

Magri et al_Quaternary disappearance_Fig 4.jpg [Figure]

Magri et al_Quaternary disappearance_Fig 5.jpg [Figure]

Magri et al_Quaternary disappearance_Fig 6.jpg [Figure]

Magri et al_Quaternary disappearance_Fig 7.jpg [Figure]

Magri et al_Quaternary disappearance_Fig 8.jpg [Figure]

Magri et al_Quaternary disappearance_Table 1.docx [Table]

Magri et al_Highlights.docx [Highlights]

To view all the submission files, including those not included in the PDF, click on the manuscript title on your EVISE Homepage, then click 'Download zip file'. 
Dear Editor,

Please find uploaded the manuscript "Quaternary disappearance of tree taxa from Southern Europe: timing and trends" by Donatella Magri, Federico Di Rita, Josu Aranbarri Erkiaga, William Fletcher, Penélope González Sampériz.

All authors have materially participated in the collection of data and in the article preparation. They have seen and approved the final version of the manuscript being submitted. The article is the authors' original work, hasn't received prior publication and isn't under consideration for publication elsewhere.

This manuscript is an invited paper (Editor: Pepe Carrion).

Yours sincerely,

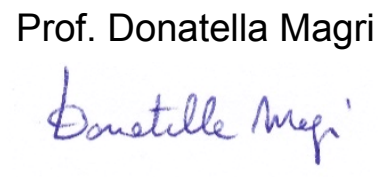


Title:

2 Quaternary disappearance of tree taxa from Southern Europe: timing and trends

4 Authors:

5 Donatella Magri ${ }^{1}$, Federico Di Rita ${ }^{1}$, Josu Aranbarri Erkiaga ${ }^{2}$, William Fletcher ${ }^{3}$, Penélope González Sampériz ${ }^{4}$

$9{ }^{1}$ Department of Environmental Biology, Sapienza University of Rome, Piazzale Aldo Moro, 5, 00185 Roma, 10 Italy

$11{ }^{2}$ Department of Geography, Prehistory and Archaeology, University of Basque Country, C/ Tomás y Valiente $12 \mathrm{~s} / \mathrm{n}, 01006$ Vitoria-Gasteiz, Spain

$13{ }^{3}$ Geography, School of Environment, Education and Development, The University of Manchester, Oxfrod 14 Road, Manchester M13 9PL, UK

$15{ }^{4}$ Pyrenean Institute of Ecology (IPE-CSIC), Av/ Montañana 1005, 50059 Zaragoza, Spain

18 Corresponding author:

19 Donatella Magri

20 e-mail: donatella.magri@uniroma1.it 
24 A hundred pollen and macrofossil records over the Iberian Peninsula, Southern France, the Italian Peninsula, Greece and the Aegean, and the southwestern Black Sea area have formed the basis for a review on the Quaternary extirpation of tree populations from Southern Europe. Following a discussion of the caveats/challenges about using pollen data, the Quaternary history of tree taxa has been reconstructed with attention to Taxodium/Glyptostrobus, Sciadopitys, Cathaya, Cedrus, Tsuga, Eucommia, Engelhardia, Carya, Pterocarya, Parrotia, Liquidambar, and Zelkova. The timing of extinction, distributed over the whole Quaternary, appears very diverse from one region to the other, in agreement with current biodiversity in Southern Europe. The geographical patterns of persistence/disappearance of taxa show unexpected trends and rule out a simple North to South and/or West to East trend in extirpations. In particular, it was possible to detect disjunct populations (Engelhardia), long-term persistence of taxa in restricted regions (Sciadopitys), distinct populations/species/genera in different geographical areas (Taxodium type). Some taxa that are still widespread in Europe have undergone extirpation in Mediterranean areas in the lateglacial period and Holocene (Buxus, Carpinus betulus, Picea); they provide indication on the modes of disappearance of tree populations that may be useful to evaluate correctly the vulnerability of modern fragmented plant populations. The demographic histories of tree taxa obtained by combined palaeobotanical and genetic studies is a most challenging field of research not only to assess species/population differentiation, but also to reach a better understanding of extinction processes, an essential task in the current global change 41 scenario.

\section{Key-words}




\section{Introduction}

49 The progressive disappearance of tree taxa from Europe in the course of the late Cenozoic, and their persistence in East Asia and/or eastern North America, has long been recognized. The first papers highlighting the question, based on seed floras, date back to more than one century ago (Reid and Reid, 1907; 1915). Starting in the 1950s, several "fathers" of the European palynology published pioneering studies dealing with Quaternary extinctions of plants, including van der Hammen (1951), van der Hammen et al. (1971), Zagwjin $(1957,1963,1974)$, West $(1962,1970)$, and Lona (1950). Since then, following a considerable increase in the number of published Early and Middle Pleistocene pollen records in Europe and a significant refinement of the chronological setting of the Quaternary stages, our knowledge of the timing of disappearance of tree taxa from Europe has much improved. Recently, a number of synthesis works on the history of vegetation and the Quaternary progression of plant extirpations (or regional extinctions, hereafter called extinctions) in Southern Europe have been published, describing the state of knowledge in different regions: Spain (González-Sampériz et al., 2010; Postigo-Mijarra et al., 2010), Italy (Bertini, 2010; Magri and Palombo, 2013; Martinetto, 2015), Greece (Tzedakis et al., 2006; Velitzelos at al., 2014), and Anatolia (Biltekin et al., 2015). In addition, several studies have examined the history of taxa currently extinct, or severely reduced in Europe, including Taxodium (Biltekin et al., 2015), Cathaya (Liu and Basinger, 2000), Cedrus (Magri, 2012), Carya (Orain et al., 2013), Aesculus (Ravazzi, 1994; Postigo Mijarra et al., 2008), Zelkova (Follieri et al., 1986), and Parrotia (Bińka et al., 2003). The present review paper is intended to summarize the available information obtained from the Pleistocene pollen records and from the synthesis papers, and to provide a holistic view

Previous works dealing with plant extinctions in Europe have mainly focused on two main problems: of timing and trends of tree taxa disappearance in Southern Europe.

1. Usage of abundances and/or last occurences of extinct plant taxa as biostratigraphical markers. This practice has been rather common since the beginning of pollen analysis of Plio-Pleistocene deposits. In the absence of, or in support of other chronostratigraphical constrains, the presence of locally extinct taxa in pollen records may provide useful indications about the age of study sites. Many such cases can be quoted, especially before the development of advanced chronostratigraphical tools, but 
the presence of extinct taxa in the pollen records is still considered an important biostratigraphical indicator. For example, the pollen record from La Côte in the western French Alps has been ascribed to the temperate Holsteinian interglacial, corresponding to Marine Isotope Stage (MIS) 11, on the basis of the occurrence of Pterocarya and the dominance of Abies (Field et al., 2000), according to

2. Relation between plant extinctions and climate changes. This was first raised by Reid and Reid (1915), who considered the presence of barriers to migration in the form of west-east oriented mountain ranges (e.g., Pyrenees, Alps, and Carpathians) the main cause for the extinction of taxa in NW Europe, preventing plant population migrations in response to Quaternary climate oscillations (West, 1970). Huntley (1993) suggested that the enhanced rate of extinction of genera and families in Europe during the Quaternary climate changes may depend on a much smaller area of forest vegetation persisting during glacial stages in Europe compared to eastern North America and East Asia. This reduced area is due, on the one hand, to the considerable extent of glaciated and periglacial surfaces at high latitudes, and, on the other hand, to a trend of increasing seasonality and dryness in the Mediterranean regions since the Pliocene, which according to Suc (1984) is at the origin of the 
Mediterranean evergreen vegetation, although with clear latitudinal and longitudinal gradients (Suc and Popescu, 2005). In Central and Northern Europe, most temperate trees are believed to have disappeared during the Quaternary glacial periods and migrated back during interglacial periods, but a number of them were extirpated (see list in Svenning, 2003, Suppl. Materials), and some of them are still living in Southern Europe in a relictual state (e.g., Zelkova, Aesculus, Castanea, Celtis, Cercis, Cupressus, Styrax, Juglans, Ostrya, Platanus). Svenning (2003) has found that genera of woody plants that are currently widespread in Europe have greater tolerance to cold growing season and winter temperatures with respect to regionally extinct and relictual genera, while relictual genera are more drought tolerant. This indicates that the persistence (or extinction) of tree populations in Europe is largely controlled by a deterministic ecological sorting process. Bhagwat and Willis (2008) showed that biogeographical traits (geographical distribution, habitat preference and life-history) of woody plants may have determined their ability to survive in inhospitable climates, so influencing their persistence (or extinction) in response to Pleistocene climate change. Eiserhardt et al. (2015) showed that late Cenozoic climate change induced phylogenetically selective regional extinction of northern temperate trees, leading to significant losses of phylogenetic diversity. Studying the relationships between climate oscillations and ecological traits, as well as the genetic characteristics of plants that went extinct in Europe during the Quaternary is especially important in terms of modern biodiversity conservation. This is a hot topic, as a better understanding of the ability of species to survive abrupt warming is indispensable in view of predicted global climate changes (Dawson et al., 2011). Linking studies of modern biodiversity and ecosystem patterns with paleoclimate dynamics may offer important scientific advances in both reconstructing the climatic conditions under which past extinction events happened, and inferring how present-day biodiversity patterns may be affected by climate change (Svenning et al., 2015).

Biostratigraphical and palaeoclimatic aspects have been often considered together, in connection to the question of whether Quaternary climate changes may have determined the extinction of plants in Southern Europe, in particular specific events including the Pliocene/Pleistocene transition (Popescu et al., 2010; Bertini, 2010; Jiménez-Moreno et al., 2010; Martinetto et al., 2015; Biltekin et al., 2015), the 
129 Combourieu-Nebout et al., 2015), the Middle Pleistocene revolution (Suc and Popescu, 2005; Leroy, 2007;

130 Postigo Mijarra et al., 2009, 2010; Bertini, 2010; Magri and Palombo, 2013), and specific glacial stages 131 corresponding to MIS 22, 16 and 12 (Muttoni et al., 2003; Tzedakis et al., 2006). Moreover, this question

132 implicitly involves the still open problem of whether plant extinctions were step-wise (e.g., Svenning, 2003; 133 Martinetto et al., 2015) or progressive (e.g., Bertini, 2010; Combourieu-Nebout et al., 2015, Biltekin et al., 134 2015).

135 Other aspects related to the Pleistocene disappearance of tree taxa have not been adequately discussed yet, 136 and will be encompassed in the present paper. Starting from the compilation of schematic regional records 137 of past tree populations spanning the whole Quaternary, we intend to examine:

138 - value and limitations of pollen data to reconstruct the Pleistocene extinction of tree taxa,

139 - state of the art of the Early and Middle Pleistocene palaeofloristic data available from Southern $140 \quad$ Europe,

141 Q Quaternary history of tree taxa no longer present in Southern Europe mainland,

142 - timing of tree population reduction and eventual disappearance,

143 - geographical patterns of extinction,

144 - long-term persistence areas of tree populations in Southern Europe,

145 - ongoing reduction trends in Southern European tree taxa populations, in the light of timing and $146 \quad$ trends of past tree population disappearance.

$148 \quad 2 . \quad$ Recognizing plant extinctions from pollen data: value and limitations

149 Most knowledge of Quaternary floristic change comes from fossil pollen preserved in lacustrine and marine 150 sediments. In particular, continuous and detailed pollen records, stretching over multiple glacial-interglacial 151 cycles, are of incommensurable value to reveal the presence of species outside their present range, to 
provide direct evidence of the persistence of plant populations in an area, to show the dynamics of species turnover following climate change, and to document the disappearance of taxa. They are particularly valuable when obtained from precisely dated deposits. Short records may also prove useful, especially when they are chronologically well-constrained and fill gaps of knowledge for specific time intervals. The best possible condition is the availability of pollen data from multiple dated sites that can substantiate the interpretation of rare fossil occurrences (Gavin et al., 2014), which is a main problem when dealing with extinctions.

In terms of limitations, one faces the classic problem "absence of evidence is not evidence of absence" - this may particularly be an issue for palynological detection of rare taxa when total count sizes do not typically exceed 300 grains and may be lower in the case of poor pollen concentration or recovery from geological sections. On the other hand, reworking and long-distance transport may contribute to rare observations of a particular pollen type such that its occurrence may not be indicative of contemporaneous regional presence. Application of fluorescence approaches may be informative for discrimination of reworked grains and demonstration of the occurrence of a taxon in an area (e.g. Biltekin et al., 2015). Long-distance transported pollen is particularly troublesome when the aim is to detect the presence of reduced populations undergoing extirpation, which by their nature are revealed by only rare pollen finds. For this reason, it may be very difficult to assess the disappearance of trees belonging to the Pinaceae family (e.g. Cedrus; Postigo-Mijarra et al., 2010; Magri, 2012) that are often huge producers of wind-transported pollen.

In the case of long-distance pollen occurence, palynological records may post-date the time of disappearance of a taxon from a region. For this reason, it is of great importance to consider the pollen productivity and dispersal of taxa that are now absent from Southern Europe, but still present in neighbouring geographical areas (Filipova-Marinova et al., 2010). In most cases, the last occurrences of pollen (and plant macrofossils) tend to predate the extinction of plant populations, as it is presumed that the probability of finding pollen or macroremains belonging to the very last individual existing in a region is virtually null. The error will be smaller if long continuous records are available, and larger in case of fragmentary and discontinuous records. Besides, under climatic conditions below the tolerance threshold of a species, plants may switch from 
primarily sexual to vegetative reproduction and ultimately to a non-regenerative state, such that disequilibrium populations on the verge of extirpation may be palynologically weakly visible or even invisible

180 (Tallantire, 2002). This may be relevant on centennial timescales for long-lived, stress tolerator species.

181 Therefore, it is important to be aware that the assessment of the exact timing of the extinction of plant 182 population is impossible.

183 The problem of determining the timing of plant extinctions has parallels with the difficulty of identifying 184 glacial refugia in areas far from the current distribution of species (Gavin at al., 2014), which is the subject of 185 vibrant and still unresolved discussions (Stewart and Lister, 2001; Tzedakis et al., 2013). In many cases, rare 186 pollen finds distant from the modern species ranges and occurring much later than the last local population expansion can only be considered as circumstantial and need to be confirmed and reinforced by the accumulation of different sources of evidence, for example multiple records from the same region. Besides, extinctions may be masked by taxonomic smoothing in the pollen record, which rarely permits species-level differentiation (Jackson and Weng, 1999). For this reason, the role of macrofossils is especially important, as they can often be identified with greater taxonomic precision than pollen, and they tend to be much more locally distributed from their source (Birks and Birks, 2000). Besides, in some cases, macrofossil records provide information on species whose pollen is badly preserved, for example Laurus, which we would expect to be abundant in the Mediterranean pollen records (Rodríguez-Sánchez et al., 2009), but it is only seldom found. However, the macrofossil record is generally very discontinuous in space and time, and the probability of finding macrofossils of plants on the way to extinction is very low.

Specific problems affect the study of Pleistocene plant extinctions. One possible matter of confusion is that the Gelasian Stage was included in the Pliocene until 2009, when the IUGS (International Union Geological Sciences) ratified its transfer to the Quaternary System (Gibbard et al., 2010). This change requires a careful consideration of the chronostratigraphic setting of pollen records. Going back in time to the Early and Middle 201 Pleistocene, the chronological control of pollen sequences may be highly inaccurate, as radiometric dating and tephrochronology cannot always be applied, magnetostratigraphy may not be conclusive, astronomic calibration is limited to sections with continuous sedimentation, direct correlation with oxygen isotope 
stratigraphy is limited to marine sediments, and other biostratigraphic proxies studied in the same deposits may suffer from the same chronostratigraphical uncertainties as palynology. In some cases, the margin of error may be of hundreds of thousands of years, but even so the pollen evidence may be of great value, when no other data are available.

208 When long continuous pollen records spanning multiple glacial-interglacial cycles are not available from a 209 region, the timing of plant extinctions is necessarily reconstructed through a compilation of different records, 210 thus accumulating chronological and taxonomical uncertainties. This difficulty is increased when the available 211 records come from both continental and marine environments, that are affected by different biases related 212 to pollen transportation, accumulation and preservation (Hooghiemstra et al, 2006).

213 Taxonomical uncertainties may be severe when dealing with extinct plants. It is likely that many extinct 214 species will never be recognized, as the identification of pollen at the species level is often impossible. 215 Furthermore, genus-level identification may be ambiguous. For example, Cathaya is often referred to as 216 Cathaya type, or included in Pinus haploxylon (Liu and Basinger, 2000). The distinction between Taxodium 217 and Glyptostrobus pollen is very difficult, so that it is often reported as Taxodium type, or Taxodiaceae. 218 However, many genera formerly included in the old Taxodiaceae family are now assigned to different 219 subfamilies of the Cupressaceae family (Taxodioideae: Taxodium, Glyptostrobus, and Cryptomeria; 220 Sequoioideae: Sequoia, Sequoiadendron, and Metasequoia) (Farjon, 2005). The correct assignment of 221 Taxodiaceae or Taxodium-type pollen to one or the other taxon is not possible unless the distinction is clearly 222 reported on the original paper (Bertini, 2010). Another common case is that of Zelkova pollen, which is often 223 counted together with Ulmus and grouped in an Ulmus/Zelkova type, so making it difficult to reconstruct the 224 history of this taxon, still included in the European flora.

225 A further complication, affecting several Mediterranean records of Early and Middle Pleistocene age, is that the aim of the original studies was the reconstruction of palaeoenvironmental and palaeoclimatic fluctuations rather than evaluation of plant population dynamics. For this reason, often only summary cumulative diagrams of ecological groups and a few selected taxa are reported in the published pollen 
Popescu et al., 2010; Sadori et al., 2016). In some cases, a list of the identified taxa is available (Klotz et al.,

231 2006; Degeai et al., 2013), but much uncertainty remains as to the abundance and the age of the finds. It is 232 unfortunate that the full pollen records for these sites are not published and available to the scientific 233 community, after having required much work and effort.

\section{South European records of Quaternary plant extirpations}

236 We have reviewed a hundred Quaternary pollen records, showing the history of taxa that have disappeared 237 from Southern Europe mainland (Fig. 1 and Table 1). These records were dated by different methods, 238 including radiometric dates and tephrochronology, magnetotratigraphy, counting of annual laminated 239 sediments, astronomic calibration, correlation with paleontological records, or direct correlation with oxygen 240 isotope curves in the case of marine sediments (Table 1). In addition to many records spanning multiple 241 glacial-interglacial cycles, several well-dated shorter records conveniently fill gaps of knowledge for specific 242 time intervals (e.g., Colle Curti: Bertini, 2000; Alleret Maar AL2: Pastre et al., 2007; Cal Guardiola: Postigo 243 Mijarra, 2007). In same cases, also sequences that are not chronologically well constrained, but that fill large 244 gaps of information, have been considered, for example the records from Tres Pins (Leroy, 2007) and Saint 245 Macaire (Leroy et al. 1994), without which the information on the vegetation history in NE Spain and S France 246 during the late Early Pleistocene would be very limited.

247 We present here a number of regional overviews, necessarily limited to the most important sites, presented 248 in the form of a schematic compilation of selected pollen records from peri-Iberian marine cores (Fig. 2) and 249 Northeastern Spain-Southern France $\left(<46^{\circ} \mathrm{N}\right)$ in Fig. 2, Northern $\left(>44^{\circ} \mathrm{N}\right.$; Fig. 3) and Central Italy $\left(41^{\circ}-44^{\circ} \mathrm{N}\right)$ 250 in Fig. 3, Southern Italy $\left(<41^{\circ} \mathrm{N}\right)$, Greece and the Aegean in Fig. 4, and Tenaghi Philippon in Macedonia 251 (Tzedakis et al., 2006) and site DSDP 380 from the Black Sea (Biltekin et al., 2015) in Fig. 5. This is at the 252 margin of Southern Europe, but may be considered an important bridge towards the the Anatolian-Caucasus253 Hyrcanian region that still hosts several species currently extinct from the European mainland. In some cases, 254 pollen data are complemented by macrofossil data. 


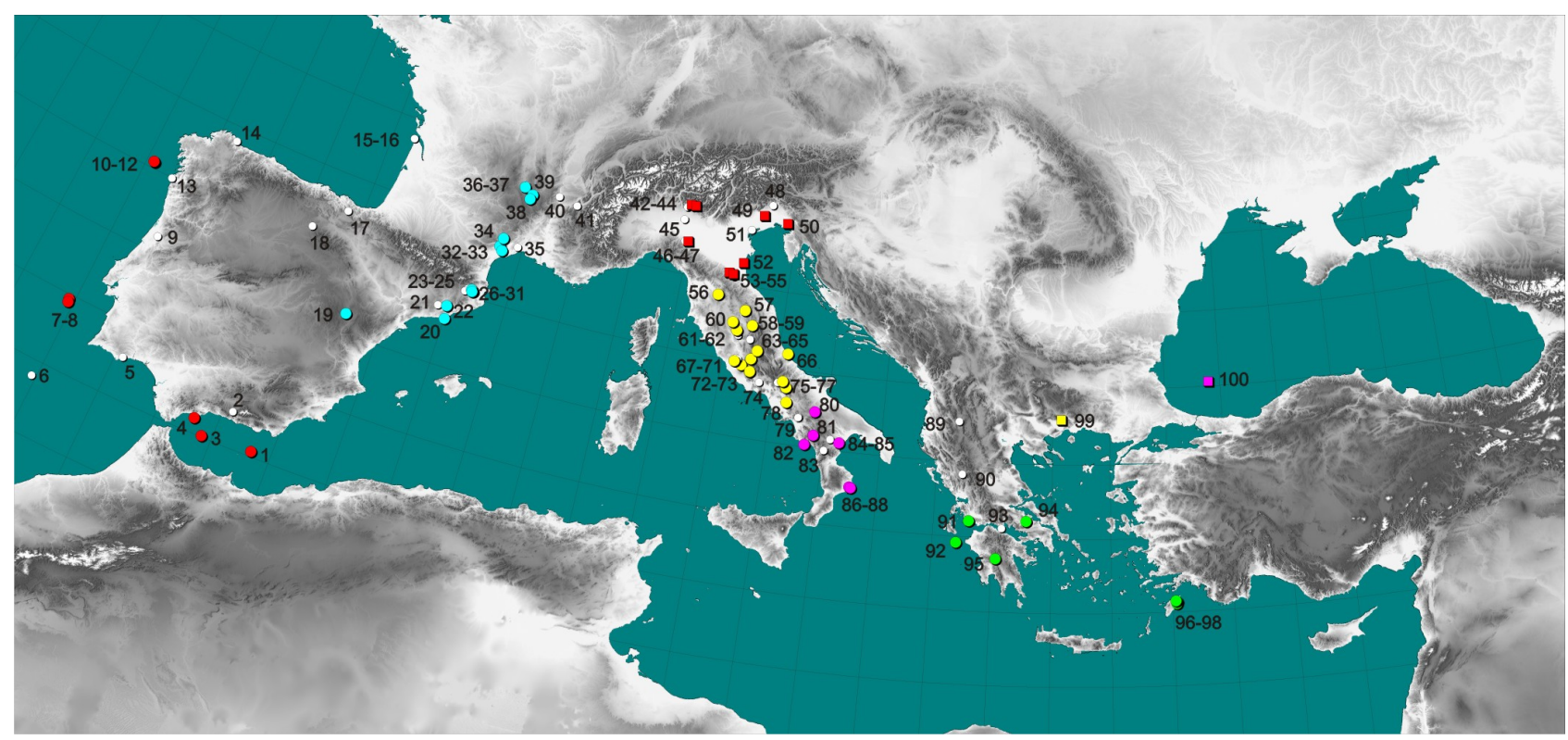

Fig. 1. Location of the Quaternary records considered in this paper. Numbering of the sites follows Table 1.

259 Red dots represent the peri-Iberian marine sites included in Fig. 2; blue dots correspond to the sites from

260 NW Iberia and S France represented in Fig. 2; red squares include sites from N Italy (Fig. 3); yellow dots 261 correspond to sites from central Italy of Fig. 3; pink dots are sites from S Italy represented in Fig. 4; green 262 dots include Greece and the Aegean (Fig. 4); the blue square corresponds to the site of Tenaghi Philippon 263 (Fig. 5) and the pink square to DSDP site 380 (Fig. 5). White dots indicate the location of sites not represented 264 in Figs 2-5 but cited in the text. 
Table 1. List of the vegetation records represented in Fig. 1.

\begin{tabular}{|c|c|c|c|c|c|c|}
\hline $\begin{array}{c}\text { Site } \\
\text { number }\end{array}$ & Site & $\begin{array}{l}\text { Age (ka) } \\
\text { MIS }\end{array}$ & $\begin{array}{l}\text { Pollen (P) } \\
\text { Macrofossil } \\
\text { (M) }\end{array}$ & $\begin{array}{l}\text { Marine (M) } \\
\text { Continental } \\
\text { (C) }\end{array}$ & Chonological control & References \\
\hline 1 & MD95-2043 & $48-2 \mathrm{ka}$ & $\mathrm{P}$ & M & 14C, event stratigraphy & $\begin{array}{l}\text { Sanchez Goñi et al., } \\
\text { 2002; Fletcher and } \\
\text { Sanchez Goñi, } 2008\end{array}$ \\
\hline 2 & Padul & $100-0 \mathrm{ka}$ & $P$ & C & $\begin{array}{l}14 C \text { and vegetation } \\
\text { history }\end{array}$ & Pons and Reille, 1988 \\
\hline 3 & ODP976 & MIS 31-23 & $\mathrm{P}$ & M & $\begin{array}{l}\text { Oxygen isotope } \\
\text { stratigraphy }\end{array}$ & $\begin{array}{l}\text { Joannin 2007; Joannin } \\
\text { et al., 2011; } \\
\text { Combourieu Nebout } \\
\text { et al., } 2009\end{array}$ \\
\hline 4 & Andalucia G1 & $\begin{array}{l}\text { Miocene- } \\
\text { Gelasian }\end{array}$ & $P$ & M & $\begin{array}{l}\text { Oxygen isotope } \\
\text { stratigraphy }\end{array}$ & Feddi et al., 2011 \\
\hline 5 & Morgandinho & $\begin{array}{l}\text { Ealry-Middle } \\
\text { Pleistocene }\end{array}$ & $\mathrm{P}$ & C & Micromammals & Antunes et al., 1986 \\
\hline 6 & Site U1385 & MIS 38 & $P$ & M & Orbital tuning & Tzedakis et al., 2015 \\
\hline 7 & MD95-2042 & MIS 6-2 & $\mathrm{P}$ & M & $\begin{array}{l}14 C \text { and Oxygen isotope } \\
\text { stratigraphy }\end{array}$ & $\begin{array}{l}\text { Sanchez Goñi et al., } \\
1999\end{array}$ \\
\hline 8 & MD01-2443 & $345-180 \mathrm{ka}$ & $\mathrm{P}$ & M & $\begin{array}{l}\text { Oxygen isotope } \\
\text { stratigraphy }\end{array}$ & Roucoux et al., 2006 \\
\hline 9 & Monsarros & $\begin{array}{c}\text { Plio- } \\
\text { Pleistocene }\end{array}$ & $\mathrm{P}$ & C & Stratigraphy & Vieira, 2009 \\
\hline 10 & MD03-2697 & $340-270 \mathrm{ka}$ & $P$ & $M$ & $\begin{array}{l}\text { Oxygen isotope } \\
\text { stratigraphy }\end{array}$ & Desprat et al., 2009 \\
\hline 11 & MD01-2447 & $\begin{array}{c}430-360 ; \\
250-180 \mathrm{ka}\end{array}$ & $\mathrm{P}$ & M & $\begin{array}{l}\text { Oxygen isotope } \\
\text { stratigraphy }\end{array}$ & Desprat et al., 2005 \\
\hline 12 & MD99-2331 & MIS 5-2 & $P$ & M & 14C, event stratigraphy & $\begin{array}{l}\text { Sanchez-Goñi et al., } \\
2005,2008\end{array}$ \\
\hline 13 & $\begin{array}{l}\text { Santa Maria de } \\
\text { Oia }\end{array}$ & MIS 5-3 & $\mathrm{P}$ & $\begin{array}{c}\text { C-M } \\
\text { (coastal) }\end{array}$ & 14C, coastal stratigraphy & $\begin{array}{l}\text { Gómez-Orellana et al., } \\
2013\end{array}$ \\
\hline 14 & Area Longa & MIS 5-3 & $P$ & $\begin{array}{c}\mathrm{C}-\mathrm{M} \\
\text { (coastal) }\end{array}$ & 14C, coastal stratigraphy & $\begin{array}{l}\text { Gómez-Orellana et al., } \\
2007\end{array}$ \\
\hline 15 & $\begin{array}{l}\text { Pointe de la } \\
\text { Négade North }\end{array}$ & $\begin{array}{c}\text { Early } \\
\text { Pleistocene }\end{array}$ & $\mathrm{P}+\mathrm{M}$ & M & Pollen biostratigraphy & $\begin{array}{l}\text { O'Brien and Jones, } \\
2003\end{array}$ \\
\hline 16 & La Balise & MIS 11 & $\mathrm{P}+\mathrm{M}$ & M & Pollen biostratigraphy & $\begin{array}{l}\text { O'Brien and Jones, } \\
2003\end{array}$ \\
\hline 17 & Lezetxiki & MIS 3 & $\mathrm{P}$ & C & $\begin{array}{l}\text { 14C, archaeological data } \\
\text { (lithic tools) }\end{array}$ & Sánchez-Goñi, 1992 \\
\hline 18 & Atapuerca & $900-400$ ka & $\mathrm{P}$ & C & Luminiscence & $\begin{array}{l}\text { García-Antón \& Sainz- } \\
\text { Ollero, } 1991\end{array}$ \\
\hline 19 & $\begin{array}{l}\text { Cañizar de } \\
\text { Villaquemado }\end{array}$ & MIS 5-1 & $P$ & C & $14 C$ and OSL dating & $\begin{array}{l}\text { González-Sampériz et } \\
\text { al., 2013; Aranbarri et } \\
\text { al., 2014; García- } \\
\text { Prieto, } 2015\end{array}$ \\
\hline 20 & Garraf & $\begin{array}{l}5300-1750 \\
\text { ka }\end{array}$ & $P$ & M & $\begin{array}{l}\text { Foraminifer } \\
\text { biostratigraphy }\end{array}$ & $\begin{array}{l}\text { Suc and Cravatte, } \\
1982\end{array}$ \\
\hline 21 & Abric Romaní & 70-40 ka & $P$ & C & $\mathrm{U} / \mathrm{Th}$ & Burjachs et al., 2012 \\
\hline 22 & Cal Guardiola & $1200-800$ ka & P-M & C & $\begin{array}{l}\text { Micromammals and } \\
\text { palaeomagnetism }\end{array}$ & $\begin{array}{l}\text { Postigo Mijarra et al., } \\
2007\end{array}$ \\
\hline 23 & Val d'en Bas & $250 \mathrm{ka}$ & $P$ & C & Volcanic crust & Cross et al., 1986 \\
\hline 24 & $\begin{array}{l}\text { Pla de l'Estany- } \\
\text { Garrotxa }\end{array}$ & MIS 5?-1 & $P$ & C & $\begin{array}{l}\text { Vegetation history and } \\
14 C \text { for the upper part }\end{array}$ & Burjachs, 1990 \\
\hline 25 & $\begin{array}{l}\text { Pla de l'Estany- } \\
\text { Incarcal-Crespià }\end{array}$ & $\begin{array}{c}\text { Plio- } \\
\text { Pleistocene }\end{array}$ & $M$ & C & $\begin{array}{l}\text { Fauna (Mammals } \\
\text { biostratigraphy) }\end{array}$ & $\begin{array}{l}\text { Villalta and Vicente, } \\
\text { 1972; Suc and } \\
\text { Cravatte, 1982; } \\
\text { Roiron, } 1983\end{array}$ \\
\hline 26 & Tres Pins & $\begin{array}{l}2600-1200 \\
\text { ka }\end{array}$ & $P$ & C & $\begin{array}{l}\text { Vegetation composition } \\
\text { (presence of carya) }\end{array}$ & Leroy, 1997 \\
\hline 27 & Mas Grill & Mid- & $\mathrm{P}$ & C & Vegetation history (older & Geurts, 1977; 1979 \\
\hline
\end{tabular}




\begin{tabular}{|c|c|c|c|c|c|c|}
\hline & & Pleistocene? & & & than Bòbila Ordis) & \\
\hline 28 & Bòbila-Ordis & MIS 36-33 & $P$ & C & $\begin{array}{l}\text { Micromammals and } \\
\text { palaeomagnetism }\end{array}$ & $\begin{array}{l}\text { Løvlie and Leroy, } \\
\text { 1995; Leroy, } 2008\end{array}$ \\
\hline 29 & Banyoles & $1000-950 \mathrm{ka}$ & $\mathrm{P}$ & C & & $\begin{array}{l}\text { Julia Bruguès and Suc, } \\
1980\end{array}$ \\
\hline 30 & Molí Vell & $\begin{array}{c}\text { Early } \\
\text { Pleistocene }\end{array}$ & $P$ & C & $\begin{array}{l}\text { Vegetation history } \\
\text { (younger than Bòbila } \\
\text { Ordis) }\end{array}$ & Geurts, 1977, 1979 \\
\hline 31 & Mas Miquel & $\begin{array}{c}\text { Early } \\
\text { Pleistocene }\end{array}$ & $P$ & C & $\begin{array}{l}\text { Fauna (Mammals } \\
\text { biostratigraphy) }\end{array}$ & Leroy, 1990 \\
\hline 32 & Saint-Macaire & $1400-700 \mathrm{ka}$ & $P$ & C & $\begin{array}{l}\mathrm{K} / \text { Ar dating, } \\
\text { magnetostratigraphy }\end{array}$ & Leroy et al., 1994 \\
\hline 33 & Nogaret & MIS 75 & $P$ & C & $\begin{array}{l}\text { K/Ar dating, mammal } \\
\text { biostratigraphy }\end{array}$ & $\begin{array}{l}\text { Brugal et al., 1990; } \\
\text { Leroy and Seret, } 1992\end{array}$ \\
\hline 34 & Bernasso & $\begin{array}{c}2160-1960 \\
k a\end{array}$ & $P$ & C & $\begin{array}{l}\text { K/Ar dating, } \\
\text { magnetostratigraphy }\end{array}$ & $\begin{array}{l}\text { Suc, 1978; Leroy and } \\
\text { Roiron, } 1996\end{array}$ \\
\hline 35 & Celleneuve & $\begin{array}{c}\text { Early } \\
\text { Calabrian }\end{array}$ & $\mathrm{P}$ & C-M & Biostratigraphy & Suc, 1973 \\
\hline 36 & Alleret & MIS 17-15 & $P$ & C & $\begin{array}{l}\text { Tephrochronology, K/Ar } \\
\text { and Ar/Ar dating }\end{array}$ & $\begin{array}{l}\text { Pastre et al., 2007; } \\
\text { Degeai et al., } 2013\end{array}$ \\
\hline 37 & Senèze & MIS 85-76 & $P$ & C & $\begin{array}{l}\text { Ar/Ar dating, mammal } \\
\text { biostratigraphy, } \\
\text { magnetostratigraphy }\end{array}$ & $\begin{array}{l}\text { Elhaï, 1969; Roger et } \\
\text { al., } 2000\end{array}$ \\
\hline 38 & Velay maars & $430-0 \mathrm{ka}$ & $\mathrm{P}$ & C & $\begin{array}{l}\text { Biostratigraphy, } \mathrm{Ar} / \mathrm{Ar} \\
\text { dating }\end{array}$ & Reille et al., 2000 \\
\hline 39 & Ceyssac & $1000-900 \mathrm{ka}$ & $P$ & C & $\begin{array}{l}\text { K/Ar dating, } \\
\text { magnetostratigraphy }\end{array}$ & Ablin, 1991 \\
\hline 40 & Saint-Vallier & $1900 \mathrm{ka}$ & $\mathrm{P}$ & C & Biostratigraphy & Argant, 2004 \\
\hline 41 & La Côte & MIS 11 & $P$ & C & Pollen biostratigraphy & Field et al., 2000 \\
\hline 42 & Fornaci di Ranica & $\begin{array}{l}\text { MIS }(36) 30 \\
\quad \text { or } 28\end{array}$ & $\mathrm{P}, \mathrm{M}$ & C & $\begin{array}{l}\text { Magnetostratigraphy, } \\
\text { mammal biostratigraphy }\end{array}$ & Ravazzi et al., 2005 \\
\hline 43 & $\begin{array}{l}\text { Leffe-Fornace } \\
\text { Martinelli }\end{array}$ & MIS 64-22 & $P, M$ & C & $\begin{array}{l}\text { Magnetostratigraphy, } \\
\text { mammal biostratigraphy }\end{array}$ & $\begin{array}{l}\text { Ravazzi and Rossignol- } \\
\text { Strick, 1995; Ravazzi, } \\
\text { 2003; Muttoni et al., } \\
2007\end{array}$ \\
\hline 44 & Pianico Sèllere & MIS 21-19 & $P, M$ & C & $\begin{array}{l}\mathrm{K} / \mathrm{Ar} \text { and } \mathrm{Ar} / \mathrm{Ar} \text { dating, } \\
\text { mammal biostratigraphy }\end{array}$ & $\begin{array}{l}\text { Ravazzi, 2003; } \\
\text { Martinetto, } 2009\end{array}$ \\
\hline 45 & Pianengo & $1200-700 \mathrm{ka}$ & $P$ & C & Magnetostratigraphy & Muttoni et al., 2003 \\
\hline 46 & Stirone & $\begin{array}{l}5100-2200 \\
\text { ka }\end{array}$ & $P$ & $M$ & $\begin{array}{l}\text { Mollusc anf foraminifer } \\
\text { biostratigraphy }\end{array}$ & $\begin{array}{l}\text { Lona and Bertoldi, } \\
\text { 1972; Bertini, } 2001\end{array}$ \\
\hline 47 & Castell'Arquato & $\begin{array}{c}\text { Early } \\
\text { Pleistocene }\end{array}$ & $\mathrm{P}$ & M & Mollusc biostratigraphy & $\begin{array}{l}\text { Lona and Bertoldi, } \\
1972\end{array}$ \\
\hline 48 & $\begin{array}{l}\text { San Pietro di } \\
\text { Ragogna }\end{array}$ & Gelasian & $P, M$ & C & $\begin{array}{l}\text { Lithostratigraphy, } \\
\text { biostratigraphy }\end{array}$ & Martinetto et al., 2012 \\
\hline 49 & Azzano Decimo & $215-20 \mathrm{ka}$ & $P$ & C & $\begin{array}{l}14 C \text { dating, } \\
\text { biostratigraphy }\end{array}$ & Pini et al., 2009 \\
\hline 50 & Visogliano & MIS 13 or 11 & $P$ & M & Mammal biostratigraphy & $\begin{array}{l}\text { Cattani et al., 1991; } \\
\text { Abbazzi et al., } 2000\end{array}$ \\
\hline 51 & Venice & 2150-110 ka & $P$ & $M$ & $\begin{array}{l}\text { Magnetostratigraphy, } \\
\text { molluscs biostratigraphy, } \\
\text { sapropel stratigraphy }\end{array}$ & $\begin{array}{l}\text { Mullenders et al., } \\
\text { 1996, Massari et al., } \\
2004\end{array}$ \\
\hline 52 & Core 223-S17 & $130-0 \mathrm{ka}$ & $\mathrm{P}$ & $\mathrm{C} / \mathrm{M}$ & $\begin{array}{l}\text { Foraminifer and ostracod } \\
\text { biostratigraphy }\end{array}$ & Amorosi et al., 2004 \\
\hline 53 & Oriolo (Faenza) & ca. 800 ka & $M$ & $\mathrm{C} / \mathrm{M}$ & $\begin{array}{l}\text { Magnetostratigraphy, } \\
\text { molluscs biostratigraphy }\end{array}$ & $\begin{array}{l}\text { Martinetto and Sami, } \\
2001\end{array}$ \\
\hline 54 & Lamone Valley & MIS 64-46 & $P$ & $M$ & $\begin{array}{l}\text { Mollusc and ostracod } \\
\text { biostratigraphy }\end{array}$ & Fusco, 2007 \\
\hline 55 & Monte Poggiolo & $\begin{array}{c}1400-1070 ? \\
\text { ka }\end{array}$ & $P$ & $M$ & $\begin{array}{l}\text { Magnetostratigraphy, } \\
\text { molluscs } \\
\text { biostratigraphy,ESR } \\
\text { dating }\end{array}$ & Messager et al., 2011 \\
\hline 56 & Poggio Rosso & $\begin{array}{l}1900-1800 \\
\text { ka }\end{array}$ & $\mathrm{P}$ & C & Magnetostratigraphy & Bertini et al., 2010 \\
\hline
\end{tabular}




\begin{tabular}{|c|c|c|c|c|c|c|}
\hline 57 & Gubbio & $\begin{array}{c}1600-1300 ? \\
\text { Ка }\end{array}$ & $P$ & $C$ & Biostratigraphy & $\begin{array}{l}\text { Lona and Ricciardi, } \\
1961\end{array}$ \\
\hline 58 & Colle Curti & ca. $990 \mathrm{ka}$ & $P$ & $C$ & Magnetostratigraphy & Bertini, 2000 \\
\hline 59 & Cesi & 750-600? ka & $P$ & $C$ & $\begin{array}{l}\text { Magnetostratigraphy, } \\
\text { Tephrochronology }\end{array}$ & Bertini, 2000 \\
\hline 60 & Pietrafitta & $1400 ? \mathrm{ka}$ & $\mathrm{P}$ & $C$ & Mammal biostratigraphy & $\begin{array}{l}\text { Ricciardi, 1961; } \\
\text { Martinetto et al., } 2014\end{array}$ \\
\hline 61 & Fosso Bianco & MIS 100-82 & $P$ & $C$ & $\begin{array}{l}\text { Magnetostratigraphy, } \\
\text { Mammal biostratigraphy }\end{array}$ & $\begin{array}{l}\text { Pontini and Bertini } \\
2000\end{array}$ \\
\hline 62 & Dunarobba & $\begin{array}{c}3500-1500 ? \\
k a\end{array}$ & $\mathrm{P}, \mathrm{M}$ & $\mathrm{C}$ & Biostratigraphy & Martinetto et al., 2014 \\
\hline 63 & Leonessa & $\begin{array}{c}1400-1200 ? \\
\text { ka }\end{array}$ & $P$ & $C$ & Biostratigraphy & Ricciardi, 1965 \\
\hline 64 & $\begin{array}{l}\text { Madonna della } \\
\text { Strada }\end{array}$ & ca. 1250 ka & $P$ & $\mathrm{C}$ & Mammal biostratigraphy & Magri et al., 2010 \\
\hline 65 & Pagliare di Sassa & $1100 \mathrm{ka}$ & $P$ & $\mathrm{C}$ & $\begin{array}{l}\text { Magnetostratigraphy, } \\
\text { mammal biostratigraphy }\end{array}$ & Palombo et al., 2010 \\
\hline 66 & $\begin{array}{l}\text { Torre Mucchia } \\
\text { (Ortona) }\end{array}$ & MIS 17 & $P$ & M & Magnetostratigraphy & Pieruccini et al., 2016 \\
\hline 67 & Carsoli & ca. 530 & $M$ & C & Ar/Ar dating & Sadori et al., 2010 \\
\hline 68 & Peperino (Rome) & $513 \pm 3 \mathrm{ka}$ & M & C & $\mathrm{Ar} / \mathrm{Ar}$ dating & $\begin{array}{l}\text { Follieri, 2010; Marra } \\
\text { et al., } 2014\end{array}$ \\
\hline 69 & Riano & $450-350 ? \mathrm{ka}$ & $M$ & C & Mammal biostratigraphy & Follieri, 1958, 1962 \\
\hline 70 & Valle Ricca & $\begin{array}{l}2100-1800 \\
\text { ka }\end{array}$ & $P$ & $M$ & $\begin{array}{l}\text { Magnetostratigraphy, } \\
\text { biostratigraphy }\end{array}$ & $\begin{array}{l}\text { Urban et al., 1983; } \\
\text { Arias et al., } 1990\end{array}$ \\
\hline 71 & $\begin{array}{l}\text { Valle di } \\
\text { Castiglione }\end{array}$ & $250-0$ ka & $P$ & C & $\begin{array}{l}\text { Varve counting, } \\
\text { astronomic calibration }\end{array}$ & $\begin{array}{l}\text { Follieri et al., 1988, } \\
\text { 1989; Di Rita et al., } \\
2013\end{array}$ \\
\hline 72 & $\begin{array}{l}\text { Coste San } \\
\text { Giacomo }\end{array}$ & ca. 2100 ka & $P$ & C & $\begin{array}{l}\text { Magnetostratigraphy, } \\
\text { mammal biostratigraphy }\end{array}$ & Bellucci et al., 2014 \\
\hline 73 & $\begin{array}{l}\text { Fontana } \\
\text { Ranuccio }\end{array}$ & MIS 23 & $\mathrm{P}$ & C & Magnetostratigraphy & $\begin{array}{l}\text { Corrado and Magri, } \\
2011\end{array}$ \\
\hline 74 & Ceprano & MIS $15-13$ & $P$ & C & Magnetostratigraphy & Manzi et al., 2010 \\
\hline 75 & $\begin{array}{l}\text { Isernia - La } \\
\text { Pineta }\end{array}$ & 900-700 ka & $P$ & C & $\begin{array}{l}\text { Magnetostratigraphy, } \\
\text { Ar/Ar dating }\end{array}$ & Lebreton, 2002 \\
\hline 76 & Sessano & MIS $14-13$ & $P$ & C & $\begin{array}{l}\text { Magnetostratigraphy, } \\
\text { Tephrochronology, } \mathrm{Ar} / \mathrm{Ar} \\
\text { dating }\end{array}$ & $\begin{array}{l}\text { Russo Ermolli et al., } \\
\text { 2010a, } 2015\end{array}$ \\
\hline 77 & Boiano & MIS 13-9 & $P$ & C & $\begin{array}{l}\text { Ar/Ar dating, } \\
\text { tephrochronology }\end{array}$ & $\begin{array}{l}\text { Orain et al., } 2013 \text {, } \\
\text { 2015; Russo Ermolli et } \\
\text { al., } 2015\end{array}$ \\
\hline 78 & Saticula & ca. 1200 ka & $P$ & $\mathrm{C}$ & Mammal biostratigraphy & $\begin{array}{l}\text { Russo Ermolli et al., } \\
2010 \mathrm{~b}\end{array}$ \\
\hline 79 & Acerno & MIS $13-12$ & $P$ & $\mathrm{C}$ & tephra, Ar/Ar dating & $\begin{array}{l}\text { Munno et al., 2001; } \\
\text { Russo Ermolli et al., } \\
2015\end{array}$ \\
\hline 80 & $\begin{array}{l}\text { Lago Grande di } \\
\text { Monticchio }\end{array}$ & $130 \div 0$ & $P$ & $\mathrm{C}$ & $\begin{array}{l}14 C \text { dating, } \\
\text { tephrochronology, varve } \\
\text { counting }\end{array}$ & $\begin{array}{l}\text { Allen et al., 2000; } \\
\text { Allen and Huntley, } \\
2009\end{array}$ \\
\hline 81 & Vallo di Diano & $650-450 \mathrm{ka}$ & $P$ & $\mathrm{C}$ & tephra, Ar/Ar dating & $\begin{array}{l}\text { Russo Ermolli, 1994; } \\
\text { Russo Ermolli et al., } \\
2015\end{array}$ \\
\hline 82 & Camerota & $\begin{array}{c}1750-1600 ? \\
k a\end{array}$ & $P$ & $\mathrm{C}$ & Biostratigraphy & Brenac, 1984 \\
\hline 83 & Mercure & MIS 13 & $P$ & $\mathrm{C}$ & Tephrochronology, Ar/Ar & Petrosino et al., 2014 \\
\hline 84 & San Lorenzo & $\begin{array}{l}1200-1100 \\
\mathrm{ka}\end{array}$ & $P$ & C & $\begin{array}{l}\text { Magnetostratigraphy, } \\
\text { mammal biostratigraphy }\end{array}$ & Sabato et al., 2005 \\
\hline 85 & $\begin{array}{l}\text { Montalbano } \\
\text { Jonico }\end{array}$ & $1250-900 \mathrm{ka}$ & $P$ & $M$ & $\begin{array}{l}\text { Ar/Ar dating, Oxygen } \\
\text { isotope stratigraphy }\end{array}$ & $\begin{array}{l}\text { Joannin et al., 2008; } \\
\text { Bertini et al., } 2015\end{array}$ \\
\hline 86 & Semaforo-Vrica & $\begin{array}{l}2460-2110 \\
\mathrm{ka}\end{array}$ & $P$ & $M$ & $\begin{array}{l}\text { Magnetostratigraphy, } \\
\text { foraminifer } \\
\text { biostratigraphy, K/Ar }\end{array}$ & $\begin{array}{l}\text { Combourieu-Nebout } \\
\text { and Vergnaud- } \\
\text { Grazzini, 1991; }\end{array}$ \\
\hline
\end{tabular}




\begin{tabular}{|c|c|c|c|c|c|c|}
\hline & & & & & dating & $\begin{array}{l}\text { Combourieu-Nebout, } \\
\text { 1993; Klotz et al., } \\
2006\end{array}$ \\
\hline 87 & Santa Lucia & MIS 43-40 & $P$ & $M$ & $\begin{array}{l}\text { Biostratigraphy, Oxygen } \\
\text { isotope stratigraphy }\end{array}$ & Joannin et al., 2007b \\
\hline 88 & Valle di Manche & MIS 20-18 & $P$ & $M$ & $\begin{array}{l}\text { Magnetostratigraphy, } \\
\text { Oxygen isotope } \\
\text { stratigraphy, } \\
\text { Tephrochronology, } \\
\text { Biostratigraphy, Ar/Ar } \\
\text { dating }\end{array}$ & Capraro et al., 2005 \\
\hline 89 & Ohrid & 500-0 ka & $P$ & C & 14C, tephra, stratigraphy & $\begin{array}{l}\text { Wagner et al., 2009, } \\
\text { 2014; Sadori et al., } \\
2016\end{array}$ \\
\hline 90 & Ioannina & 450-0 ka & $P$ & C & Pollen biostratigraphy & $\begin{array}{l}\text { Tzedakis, 1994; } \\
\text { Roucoux et al., } 2008\end{array}$ \\
\hline 91 & Acheloos Delta & 5-3 ka & $P$ & $M$ & $14 C$ dating & Fouache et al., 2005 \\
\hline 92 & Zakynthos & $\begin{array}{c}2000-1800 \\
\text { ka }\end{array}$ & $P$ & $M$ & $\begin{array}{l}\text { Magnetostratigraphy, } \\
\text { oxygen isotope } \\
\text { stratigraphy }\end{array}$ & Subally et al., 1999 \\
\hline 93 & Gulf of Corinth & $1800-600$ ka & $\mathrm{P}$ & M & $\begin{array}{l}\text { Pollen biostratigraphy, } \\
\text { regional stratigraphical } \\
\text { correlations }\end{array}$ & Rohais et al., 2007 \\
\hline 94 & Kopais & $500-2 \mathrm{ka}$ & $P$ & C & Pollen biostratigraphy & $\begin{array}{l}\text { Tzedakis, 1999; Okuda } \\
\text { et al., } 2001\end{array}$ \\
\hline 95 & $\begin{array}{l}\text { Megalopolis } \\
\text { Basin }\end{array}$ & $650-300 \mathrm{ka}$ & $P$ & C & $\begin{array}{l}\text { Magnetostratigraphy, } \\
\text { palaeontology }\end{array}$ & Okuda et al., 2002 \\
\hline 96 & Kallithea & Calabrian & M & C & Mollusc biostratigaphy & $\begin{array}{l}\text { Mai and Velitzelos, } \\
\text { 2007; Velitzelos et al., } \\
2014\end{array}$ \\
\hline 97 & Kolymbia Bay & $500 \mathrm{ka}$ & M & M & Magnetostratigraphy & Boyd, 2009 \\
\hline 98 & Tsampika Bay & MIS 42-1 & $P$ & M & $\begin{array}{l}\text { Magnetostratigraphy, } \\
\text { Oxygen isotope } \\
\text { stratigraphy }\end{array}$ & Joannin et al., $2007 a$ \\
\hline 99 & $\begin{array}{l}\text { Tenaghi } \\
\text { Philippon }\end{array}$ & 1350-0 ka & $P$ & $\mathrm{C}$ & Pollen-orbital tuning & $\begin{array}{l}\text { Wijmstra, 1969; } \\
\text { Wijmstra and Smit, } \\
\text { 1976; Van der Wiel } \\
\text { and Wijmstra, } \\
\text { 1987a,b; Tzedakis et } \\
\text { al., 2006; Fletcher et } \\
\text { al., 2013; Pross et al., } \\
2015\end{array}$ \\
\hline 100 & DSDP Site 380 & $6000-0 \mathrm{ka}$ & $P$ & $M$ & Nannoplankton & $\begin{array}{l}\text { Biltekin, 2010; } \\
\text { Popescu et al., 2010; } \\
\text { Biltekin et al., } 2015\end{array}$ \\
\hline
\end{tabular}




\subsection{Iberian Peninsula}

271 The Iberian Peninsula has always been a region of great physiographical heterogeneity over time, resulting

272 in a unique evolutionary history and particular vegetation behaviour and composition (Carrión and Leroy,

273 2010). This fact has been considered one of the main reasons for survival and/or delayed extinction of many

274 taxa in this region of southern Europe (Postigo-Mijarra et al., 2010). There are many Quaternary sites, both

275 continental and marine sequences (Fig. 2), which provide information from Iberia, although those from Early

276 and Middle Pleistocene are relatively scarce and no long continuous records such as those from France,

277 Greece or Italy are available (see compilations of González-Sampériz et al., 2010 and Postigo-Mijarra et al., 278 2010).

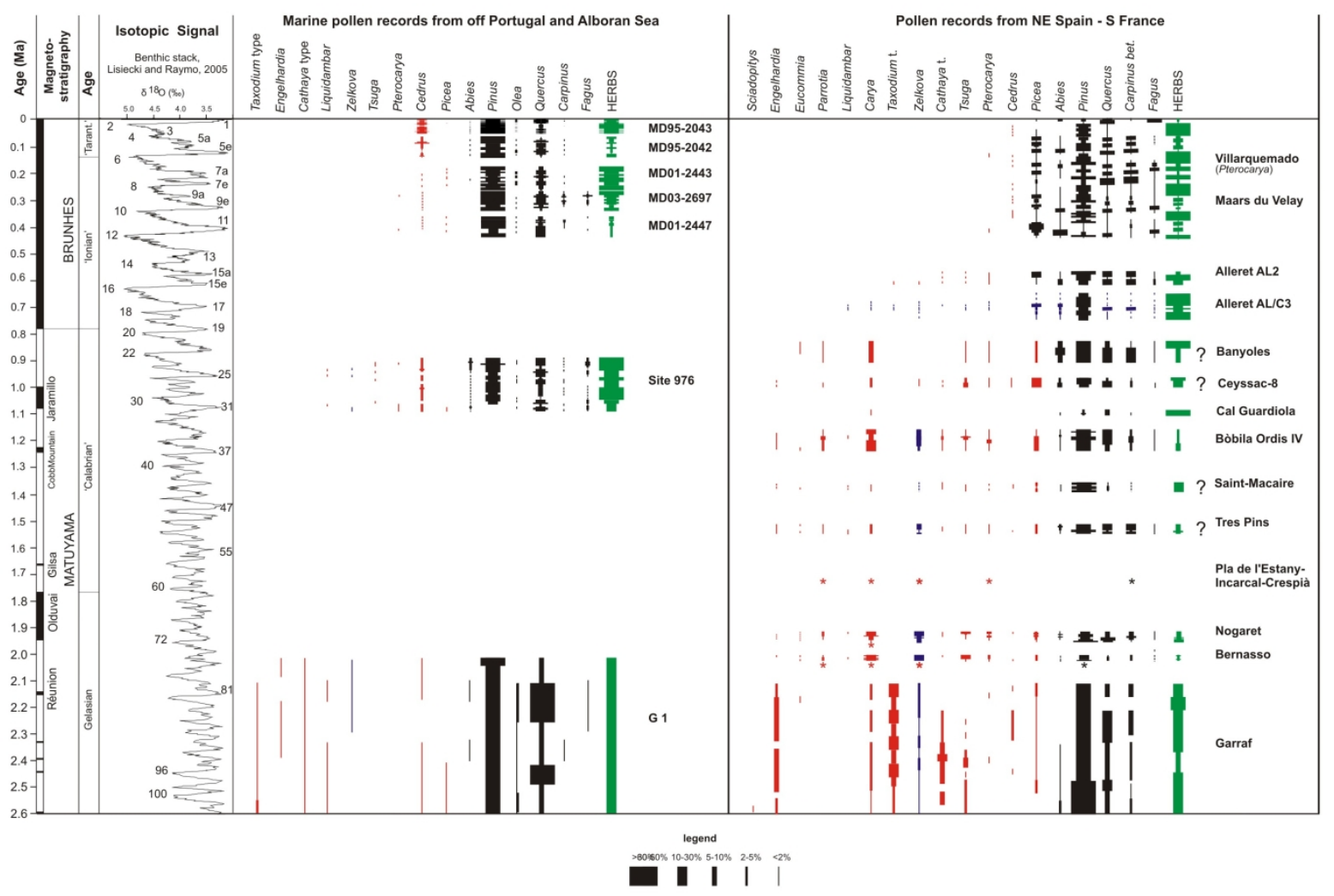

280 Fig. 2. Stratigraphical setting and schematic pollen biostratigraphy of selected taxa of Pleistocene records 281 from the Alboran Sea and off Portugal, and from NW Iberia and S France. Question marks indicate 282 uncertainties in the chronological setting of the records. Asterisks indicate plant macrofossils. Red lines 283 represent regionally extinct taxa. Blue lines represent taxa that are only mentioned in the papers or uncertain 284 determinations (e.g. Ulmus/Zelkova). 
During the Early Pleistocene (ca. 2.6-0.8 Ma, MIS 100-20), the majority of available data come from 286 Northeastern Spain (Fig. 2), thus presenting a partial image of the whole of Iberia. These include Garraf, Pla 287 de l'Estany-Incarcal-Crespià (the three names are sometimes interchanged in the literature because the 288 different outcrops are located in the same site), Mas Miquel, Tres Pins, Bòbila Ordis, Molí Vell and Cal 289 Guardiola, while ODP 976 and G1 are the only marine cores which cover this period. Monsarros, in Portugal, 290 is also considered a Plio-Pleistocene site (see location, more details of the different sequences and 291 compilation of references in both González-Sampériz et al., 2010 and Carrión (Ed.), 2012). In relation to 292 extinct taxa considered in this work, Garraf (Suc and Cravatte, 1982; Suc and Popescu, 2005) records 293 Taxodiaceae, Liquidambar, Cathaya and Eucommia; Pla de l'Estany-Incarcal-Crespià shows Carya, Pterocarya, 294 Zelkova, Parrotia and Carpinus leaf imprints (Villalta and Vicente, 1972) and pollen presence of both Carpinus 295 and Parrotiopsis (Suc and Cravatte, 1982); Mas Miquel pollen data (Geurts, 1979; Leroy, 1990) includes 296 Carpinus, Liquidambar, Carya, Pterocarya, Nyssa and even Acacia type between other meso-thermophytes; 297 Tres Pins captures Cathaya, Cedrus, Picea, Tsuga, Carpinus, Eucommia, Liquidambar, Carya, Pterocarya, 298 Parrotia and Zelkova (Leroy 1990, 1997), while in the site of Bòbila Ordis, dated at around 1.2 Ma (MIS 36299 33) (Lovlie and Leroy, 1995), Engelhardtia, Eucommia, Carpinus, Carya, Pterocarya, Tsuga, Zelkova and 300 Parrotia occur (Leroy 1990, 2008) (Fig. 2). Both Molí Vell (Geurts 1977, 1979) and Cal Guardiola (1.2-0.8 Ma: 301 Postigo-Mijarra et al. 2007) show Carya and Carpinus as well as Taxodiaceae in the case of Cal Guardiola, 302 pointing the last evidence in Iberia and one of the last in Europe for this taxon (Postigo-Mijarra et al., 2010). 303 Likewise, the Portuguese site of Monsarros (Vieira, 2009) documents the presence of Liquidambar, 304 Taxodiaceae, Engelhardia, Symplocos, Nyssa, and Cathaya, while G1 core, in the Alboran Sea, shows evidence 305 of Picea, Tsuga, Cathaya, Taxodiaceae, Carpinus, Engelhdaria and Liquidambar (Feddi et al., 2011) and ODP 306976 Liquidambar, Zelkova, Tsuga, Ptercarya, and Carpinus (Joannin et al., 2011).

307 In summary, a complex scenario emerges from the patchy, discontinuous geographical distribution of sites 308 across Iberia. Long temporal series are generally lacking and vegetation signals are usually dominated by 309 conifers and/or the herbaceous component. A varied presence of other relict taxa is nevertheless apparent 310 (González-Sampériz et al., 2010; Postigo-Mijara et al., 2010), at least near the Mediterranean and until the 311 Early-Middle Pleistocene transition (between MIS 36-18). After this transition, the last occurrences of some 
313 Taxodium type and Tsuga, can be detected (Leroy, 2008; Postigo-Mijarra et al., 2009, 2010).

314 With respect to the Middle Pleistocene (ca. 0.8-0.126 Ma, MIS 20-6), following the review of Postigo-Mijarra 315 et al. (2010), there is a noticeable increase in information related to last recognised evidence of relicts, but 316 the number of records is similar to the Early Pleistocene and again most of the sites are only fragmentary 317 sequences, with a low number of samples studied and poor chronological control (for more details see table 318 compilation in González-Sampériz et al. (2010) and individual sites description in Carrión (Ed.) (2012). 319 Nevertheless, valuable information emerges from both marine and continental sites, including some 320 archaeological sites and again not only pollen but macro-remains, too.

321 Thus, Carpinus is recorded in marine cores ODP 976 (Combourieu-Nebout et al., 1999; Joannin, 2007, 2011), 322 MD99-2331 (Sánchez-Goñi et al., 2005, 2008), MD01-2447 (Desprat et al., 2005, 2007), MD03-2697 (Desprat 323 et al., 2009) and MD01-2443 (Roucoux et al., 2006). Pterocarya occurs in both MD01-2447 during MIS 11 324 (Desprat et al., 2005) and MD03-2697 during MIS 9 (at around 298 ka BP: Desprat et al., 2009). However, a greater diversity of extinct taxa can be observed in continental areas sites (Fig. 2). This is the case of Carya, for example, which has been recorded after MIS 18 in the Banyoles area but imprecisely dated (Geurts, 1979). Val d'en Bas includes Carpinus in the spectra located below a volcanic crust dated at 250 ka ago (Cross et al., 1986). Mas Grill shows the presence of Fagus, Ostrya, Juglans and Carya (Geurts, 1979), although only five pollen samples have been studied. Carpinus is also recorded at the Northern Iberian Lezetxiki site, attributed 330 to the end of the Middle Pleistocene following the archaeological sequence (Sánchez-Goñi, 1992). The 331 Atapuerca pollen sequence, from both Galería (TG) and Gran Dolina (TD) outcrops (García-Antón and Sainz332 Ollero, 1991), records the last evidence of Cedrus, Taxodium, Platanus and Carya from inner continental areas 333 at around 0.8-0.6 Ma (TD 5-TD 8) while Carpinus, Picea or Juglans still persist in the sequence and other sites 334 until Holocene or current times in same cases. In Padul, the longest pollen sequence from southern Spain, 335 Abies, Tsuga, Fagus and Quercus, amongst other taxa, are recorded in levels probably attributed to the 336 interglacial Mindel-Riss (Holstein) despite controversy between Florschütz et al. (1971) and Pons and Reille 337 (1988) with respect to the chronology of the sequence. All these sites are located in Spain, but data from 338 Portugal is also available such as in Morgandinho (Antunes et al., 1986), where Cathaya and Keteleeria were 
present, as well as Picea (ca. 3\%), in a conifer-dominated landscape (mainly formed by Pinus) between, probably, MIS 20-17.

341 Thus, the Middle Pleistocene Iberian sites offer an informative but always incomplete view of the extinction 342 and/or persistence of relicts pointing the key role of southern European latitudes for vegetation refugia in 343 the face of intense global climatic changes such as those associated to glacial/interglacial periods and the 344 consequent adaptation, survival or disappearance of numerous taxa.

345 Finally, Iberian available sites from Late Pleistocene (González-Sampériz et al., 2010) and Holocene (Carrión 346 et al., 2010) are much more numerous than previous periods, geographically well distributed and benefit 347 from generally better chronological control, but information with respect to extinct taxa becomes limited 348 (Postigo-Mijarra et al., 2008, 2010) because Engelhardia, Eucommia, Liquidambar, Sciadopitys, Parrotia, 349 Taxodium type and Tsuga, amongst other relicts already disappeared.

350 Concerning currently extinct conifers in Iberia, Cedrus is relatively frequently present in continental 351 palynological records (marine cores from southern Iberia cannot be considered here for its potential African 352 pollen rain capture area; Fig. 2), both from the Late Pleistocene (Pons and Reille, 1988; Burjachs and Julià, 353 1994; Carrión and van Geel, 1999; Yll et al., 2003; Carrión et al., 2008; Cortés-Sánchez et al., 2008) and 354 Holocene (Pons and Reille, 1988; Carrión and van Geel, 1999; Carrión et al., 2003, 2007; Cortés-Sánchez et 355 al., 2008; Aranbarri et al., 2014).

356 New Iberian long sequences which extend from, at least, the Middle-Late Pleistocene transition and include 357 the whole Holocene, such as the Cañizar de Villarquemado record (González-Sampériz et al., 2013; García358 Prieto, 2015), Conquezuela palaeolake (González-Sampériz, pers. com.), or a new study at the well-known 359 Padul peatbog (Jiménez-Moreno, pers. comm.), are currently under study and will be published in the next 360 years. Current methodologies usually imply a multidisciplinary context of analyses and an accurate 361 independent chronology. Thus, these future results will be of great interest and could contribute to the 362 understanding of the survival history of rare taxa in the Mediterranean context. 


\subsection{Southern France}

366 Only pollen records at latitudes $<46^{\circ} \mathrm{N}$ have been considered from Southern France, where the paleofloristic 367 record of the Early Pleistocene is rather fragmented (Fig. 2). The pollen record from Senèze, dated to around 368 2.1 Ma (Roger et al., 2000), lists many "exotic trees", including Taxodium/Sequoia, Sciadopitys, Pinus 369 haploxylon, Nyssa, Liquidambar, Eleagnus, Symplocos, Carya, Pterocarya, Juglans, Eucommia, Cedrus, and 370 Tsuga (Elhaï, 1969). The site of Bernasso, which provided both pollen and plant macrofossil data, developed 371 during the time interval between ca. 2.16 and 1.96 Ma and documents the presence of a rich flora wih Cedrus, 372 Tsuga, Ecommia, Parrotia, Carya, Pterocarya, Engelhardia, Myrica, Zelkova, Carpinus orientalis, and 373 Parthenocissus (Suc, 1978; Leroy and Roiron, 1996). The Nogaret deposit, dated between 2 Ma and 1.7 Ma shows a substantially similar flora, including also scarce grains of Cathaya (Brugal et al., 1990; Leroy and Seret, 1992). The Saint-Macaire maar (NW Mediterranean coastal plain of France), considered to be deposited between 1.4 and about $0.7 \mathrm{Ma}$, presents many floristic elements typical of the Early Pleistocene, including Cathaya, Cedrus, Tsuga, Liquidambar, Carya, Pterocarya, Eucommia, Parthenocissus, and UlmusZelkova (Leroy et al., 1994). The long pollen record from Ceyssac depicts the vegetation history of the Massif Central from the beginning of the Pleistocene to approx. 0.9 Ma. The bottom part of the record, substantially confirming the presence of the taxa found at Senèze, Bernasso, Nogaret and Saint-Macaire, is not precisely 381 dated, while pollen zone 8 is bracketed between two K/Ar dates suggesting an age between 1.1 and $0.9 \mathrm{Ma}$ 382 (Ablin, 1991). It still includes a number of taxa that are not currently present in the region, including Cathaya 383 type, Cedrus, Tsuga, Parrotia, Eucommia, Carya, Pterocarya, Parthenocissus, and Zelkova. Other pollen records of Early Pleistocene age were studied from the French Pays Basques (Oldfield, 1968) and from the Médoc region (O'Brien and Jones, 2003). Although they are not set in a precise chronostratigraphic framework, they provide the important information of significant expansions of Tsuga, reaching the Atlantic coast in a time period preceding $0.8 \mathrm{Ma}$.

The vegetation history of the early Middle Pleistocene is well studied in the Alleret maar (Massif Central), which comprises two records: the oldest is dated 750 to $650 \mathrm{ka}$ and is still only partially published (Degeai et al., 2013), while the youngest is correlated with MIS 15 (Pastre et al., 2007). The flora appears impoverished with respect to the Early Pleistocene, as taxa such as Cedrus, Eucommia, Parrotia, and Parthenocissus are not 
present. Carya and Liquidambar are still recorded during MIS 17 (Degeai et al., 2013), but were absent in MIS 15 (Pastre et al., 2007). Cathaya, Tsuga, Nyssa, Pterocarya and Zelkova were still present in both records.

394 The records from the Velay (Reille et al., 2000 and references therein) constitute a benchmark for the 395 vegetation history of southern France across five glacial-interglacial cycles (MIS 11 to the present). Cathaya, 396 Nyssa, Tsuga and Zelkova are not found any more, while Pterocarya is recorded for the last time in the 397 Praclaux interglacial, correlated with MIS 11. The same age is prospected for the finds of Pterocarya in the 398 interglacial deposits from La Côte, in the western French Alps (Field et al., 2000), but a personal 399 communication of M. Reille reveals that traces of Pterocarya were found in the Massif Central in MIS 9 400 (Tzedakis et al., 2006).

\subsection{Italian Peninsula}

403 In the Italian Peninsula, a large number of Pleistocene pollen records have been published over the years, 404 documenting the presence of taxa nowadays absent from the Italian territory. Several long pollen records, 405 often spanning multiple glacial-interglacial cycles, have been studied from lacustrine sites, such as Azzano 406 Decimo (Pini et al., 2009), Leffe (Ravazzi and Rossignol-Strick, 1995; Ravazzi, 2003; Muttoni et al., 2007), 407 Pianengo (Muttoni et al., 2003), Fornaci di Ranica (Ravazzi et al., 2005), Fosso Bianco (Pontini and Bertini, 408 2000), Valle di Castiglione (Follieri et al., 1988, 1989), Vallo di Diano (Russo Ermolli, 1994), Acerno (Munno et 409 al., 2001; Russo Ermolli et al., 2015), Boiano (Orain et al., 2013), Sessano (Russo Ermolli et al., 2010a), and 410 Camerota (Brenac, 1984). Other long pollen records were obtained from marine sites, including Venice 411 (Müllenders et al., 1996, Massari et al., 2004), Stirone (Lona and Bertoldi, 1972; Bertini 2001), Lamone Valley 412 (Fusco, 2007), Valle Ricca, (Urban et al., 1983; Arias et al., 1990), Santa Lucia (Joannin et al., 2007b) 413 Montalbano Jonico (Joannin et al., 2008; Bertini et al., 2015), and Crotone (Coubourieu Nebout and Vergnaud 414 Grazzini, 1991; Combourieu-Nebout, 1993; Klotz et al., 2006; Suc et al., 2010). In addition to these long 415 sequences, many pollen records span only single glacial-interglacial cycles or shorter time intervals. 416 Nonetheless, they provide useful information about the presence/absence of plant taxa, especially when 417 they are set into a sound chronostratigraphic framework. Among them, it is worth mentioning Pianico Sèllere 418 (Ravazzi et al., 2003; Martinetto, 2009); Valle di Manche (Capraro et al., 2005), Colle Curti (Bertini, 2000), 
Fontana Ranuccio (Corrado and Magri, 2011), Mercure (Petrosino et al., 2014), and Lago Grande di 420 Monticchio (Allen et al., 2000; Allen and Huntley, 2009). A number of pollen records have been studied from 421 paleontological sites, with mammal fauna providing additional palaeoecological information. They include 422 Coste San Giacomo (Bellucci et al., 2014), Madonna della Strada (Magri et al., 2010), Poggio Rosso (Bertini et 423 al., 2010), Pagliare di Sassa (Palombo et al., 2010), Riano (Follieri, 1958, 1962), Pietrafitta (Ricciardi, 1961; Martinetto et al., 2014), Saticula (Russo Ermolli et al., 2010), and San Lorenzo in the Sant'Arcangelo Basin 425 (Sabato et al., 2005). A few pollen records were obtained from archaeological sites: Visogliano (Cattani et al., 1991; Abbazzi et al., 2000), Isernia-La Pineta (Lebreton et al., 2002), Monte Poggiolo (Messager et al., 2011), and Ceprano (Manzi et al., 2010). A large number of macrofossil sites complement the information provided by pollen records. They are mostly located in northern and central Italy (Martinetto 2001, 2009, 2015, Martinetto and Sami, 2001, Martinetto et al., 2014, 2015).

While no single pollen record in Italy spans the whole (or most) of the Quaternary, the wealth of available data has made it possible to compose a satisfactory picture of the succession of tree taxa disappearances from the Peninsula, which is presented separately for Northern ( $>44^{\circ} \mathrm{N}$; Fig. 3 ) and Central Italy $\left(44^{\circ}-41^{\circ} \mathrm{N}\right)$ in Fig. 3, and Southern Italy $\left(<41^{\circ} \mathrm{N}\right)$ in Fig. 4). These regions do not correspond exactly to the administrative subdivision of Italy, but are appropriate for our purposes.

In Northern Italy ( $>44^{\circ} \mathrm{N}$; Fig. 3), the base of the Quaternary is well represented, in continuity with the end of the Pliocene, in the Stirone section, recording the altitudinal forest development in the Northern Apennines (Italy) from 2.7 Ma to approx. 2.2 Ma (Bertini, 2001). In the Pleistocene portion of the record, a number of tree taxa are found that later disappear, including Taxodium type, Sequoia type, Sciadopitys, Cathaya, Tsuga, Cedrus, Liquidambar, Engelhardia, Carya, Pterocarya, Zelkova, and Parthenocissus. These taxa were still present, and in some cases abundant, in the marine sediment of Calabrian age from the Lamone Valley, where also Nyssa and cf. Parrotia were found (Fusco, 2007). A clear reduction in the recorded taxa appear in the pre-Jaramillo record from Leffe-Fornace Martinelli (Ravazzi and Rossignol-Strick, 1995; Ravazzi, 2003; Muttoni et al., 2007), where Sciadopitys, Cathaya, Parrotia, and Engelhardia are not reported, but other most interesting taxa are represented, including Aesculus (Ravazzi, 1994), Styrax, and Parthenocissus. It is important to note that Taxodiaceae, still abundant in the Lamone Valley, are only found at the base of the 

in the section of Pianico Sèllere (Ravazzi, 2003; Martinetto, 2009), whose fossil flora does not display taxa typical of the Early Pleistocene (e.g. Taxodiaceae, Carya, Liquidambar, and Eucommia), but shows the last sporadic appearance of Cedrus, which was abundant at Leffe. Parrotia and Zelkova are still found in the macroflora of Oriolo (Martinetto and Sami, 2001), but never again in the mid-Middle Pleistocene site of Visogliano (350-500 ka), where also Carya and Tsuga were lost, but Pterocarya was still present (Cattani et al., 1991; Falguères et al., 2008). The Azzano Decimo record (Pini et al., 2009), spanning the last 215 ka, does not display any tree taxon currently absent from the peninsula. However, pollen records from the Eastern Po Plain (Amorosi et al., 2004) and from Venice (Müllenders et al., 1996) document the presence of Zelkova until the end of the Eemian interglacial.

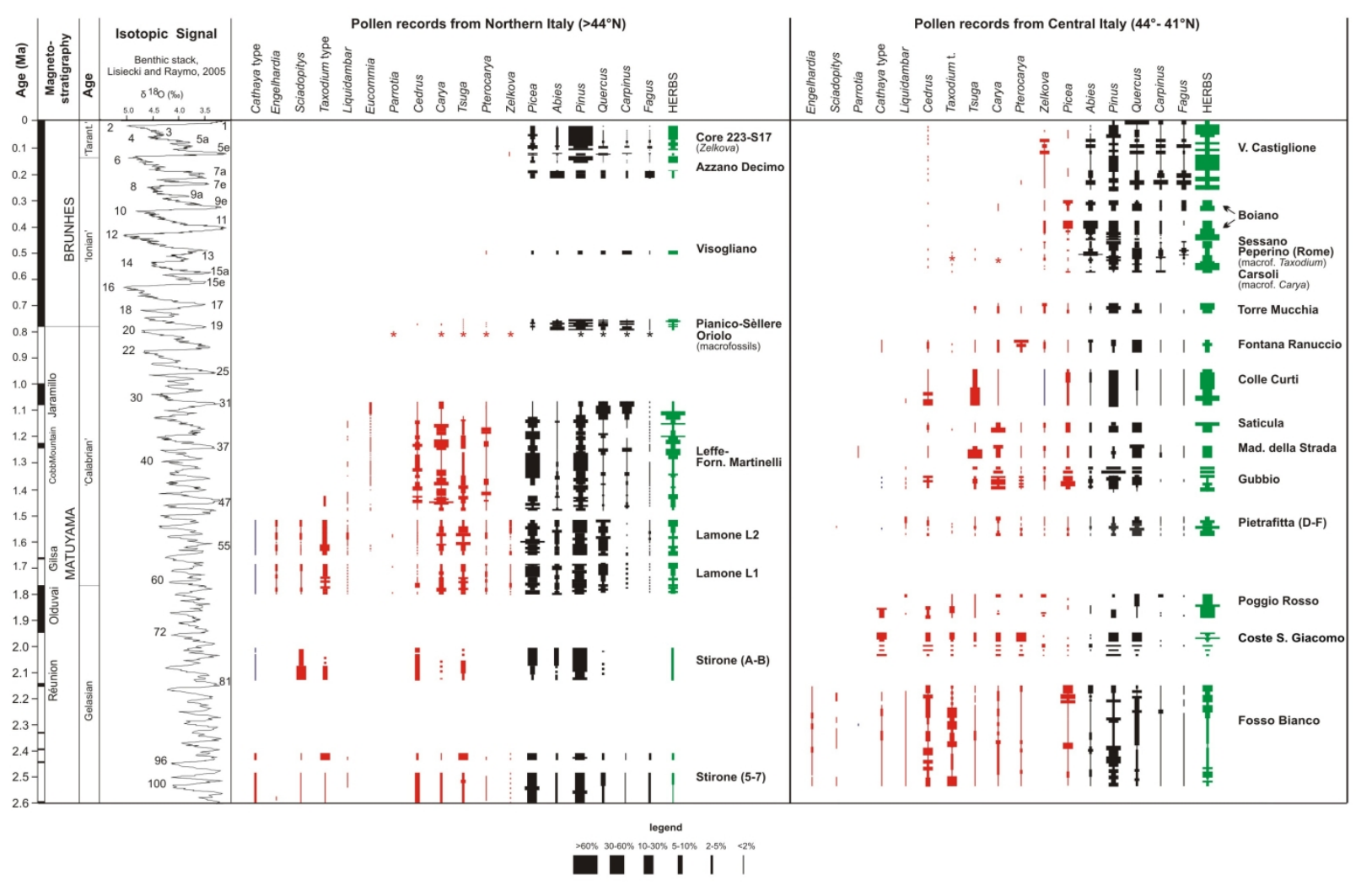

457 Fig. 3. Stratigraphical setting and schematic pollen biostratigraphy of selected taxa of Pleistocene records 458 from $\mathrm{N}$ Italy $\left(>44^{\circ} \mathrm{N}\right)$ and Central Italy $\left(44^{\circ}-41^{\circ} \mathrm{N}\right)$. Note that the sites of Sessano and Boiano are 459 administratively located in S Italy. Question marks indicate uncertainties in the chronological setting of the 460 records. Asterisks indicate plant macrofossils. Red lines represent regionally extinct taxa. Blue lines represent 461 taxa that are only mentioned in the papers or uncertain determinations (e.g. Ulmus/Zelkova). 


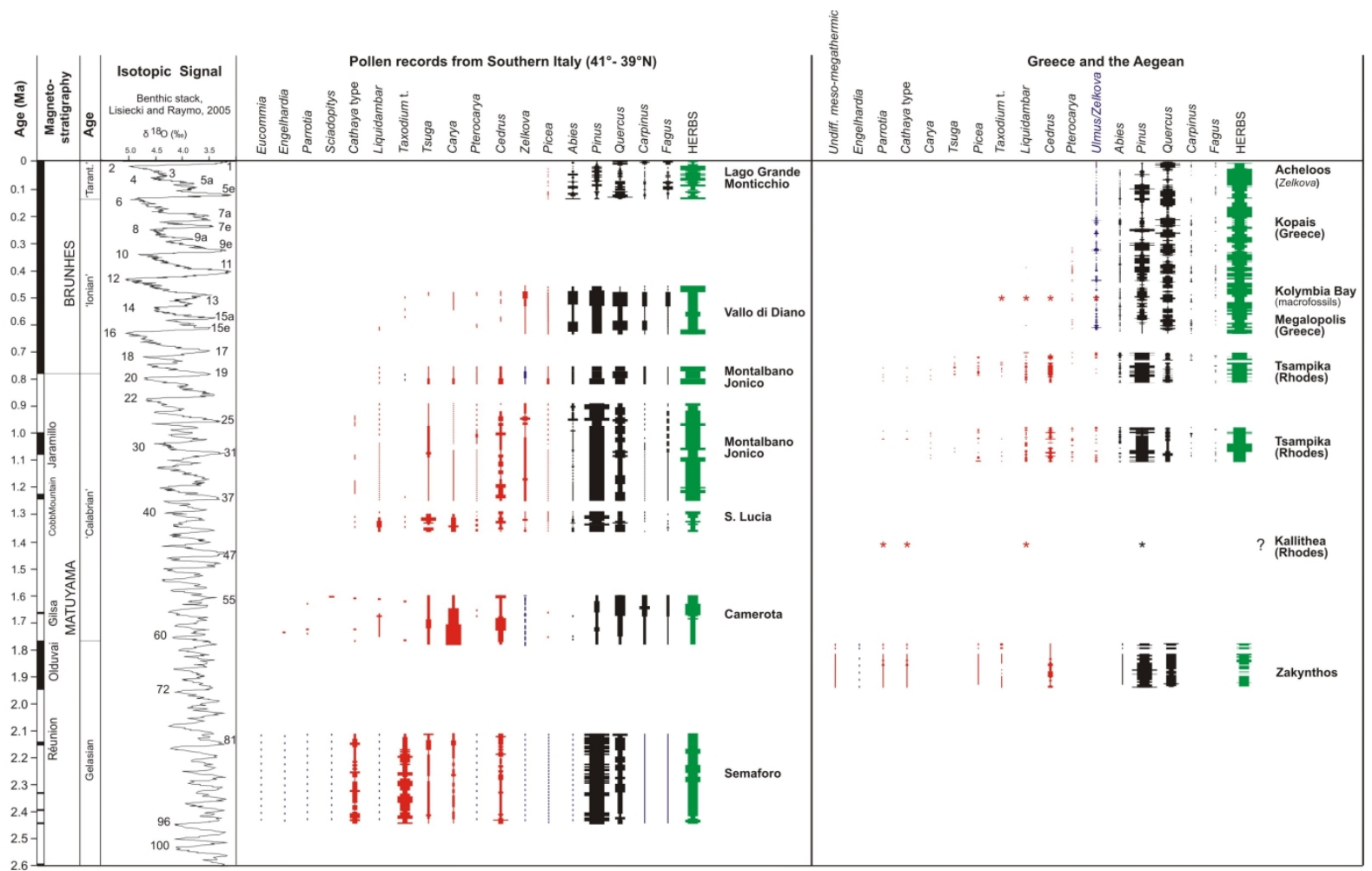

462

In Central Italy $\left(44^{\circ}-41^{\circ} \mathrm{N}\right.$; Fig. 3), Taxodium type is abundant in all the Gelasian records (Fosso Bianco: Pontini and Bertini, 2000; Poggio Rosso: Bertini et al., 2010; Coste San Giacomo: Bellucci et al., 2014). However, at Fosso Bianco there are still many Pliocene taxa that are not found in the Quaternary records of Central Italy, including Panax type (Araliaceae), Engelhardia, Nyssa, Symplocos, and cf. Parthenocissus. It is also worth noting the last occurrence of Aesculus in Central Italy, recorded at Poggio Rosso. During the Calabrian, a number of sites that are not precisely dated (Pietrafitta: Ricciardi, 1961; Martinetto et al., 2014; Gubbio: Lona and Ricciardi, 1961; Leonessa: Ricciardi, 1965; Madonna della Strada: Magri et al., 2010; and Saticula: Russo Ermolli et al., 2010b), together with other records dated by means of magnetostratigraphy (Colle Curti: Bertini, 2000; Fontana Ranuccio: Corrado and Magri, 2011) show the last occurrences of Sciadopitys (Pietrafitta), Parrotia (Madonna della Strada), Liquidambar (Colle Curti), Cathaya type (Fontana Ranuccio) and the last continuous record of Cedrus (Fontana Ranuccio). Sparse pollen grains of Taxodium type are still 
found in the Calabrian records. In the early Middle Pleistocene, the Torre Mucchia record, correlated with

MIS 17 (Pieruccini et al., 2016), displays the last significant abundance (>3\%) of Tsuga and Carya, which are

recorded for the last time during interglacial periods corresponding to MIS 13 (Sessano: Russo Ermolli et al., 2010a, 2015) and MIS 9 (Boiano: Orain et al., 2013; Russo Ermolli et al., 2015), respectively. The last occurrence of Pterocarya, still very abundant in both the pollen and macrofossil records from Riano (Follieri, 1958, 1962), likely correlated to MIS 11, is recorded at Valle di Castiglione around 200 ka (Follieri et al., 1988). Zelkova, a main component of the Eemian vegetation at Valle di Castiglione (Follieri et al., 1986, 1988, 1989) disappears from several records in Central Italy at the end of MIS 3, while Picea is found with percentages >2\% until about 25 ka (Follieri et al., 1998; Magri, 1999; Magri and Sadori, 1999).

In Southern Italy $\left(<41^{\circ} \mathrm{N}\right.$; Fig. 4), all the records of Early Pleistocene age were studied from marine sediments, with the exception of Camerota (Brenac, 1984). The long Crotone sequence, including the Semaforo (2.46 to $2.11 \mathrm{Ma}$ ) and Vrica (2.2 to $1.36 \mathrm{Ma}$ ) sections (Combourieu-Nebout and Vergnaud-Grazzini, 1991; 491 Combourieu-Nebout, 1993; Klotz et al., 2006; Suc et al., 2010), provides a well-dated and detailed record of the Gelasian vegetation, including a large number of taxa nowadays absent from Italy, belonging to the subtropical humid forest: Cathaya, Distyllium, Sciadopitys, Taxodium, Engelhardia, Myrica, Magnolia, Nyssa, Symplocos, and Sapotaceae. Besides, there were a number of taxa typical of the deciduous forest (Liquidambar, Parrotia, Carya, Pterocarya, Eucommia) and of the altitudinal coniferous belt (Cedrus, Picea, Tsuga), that are not living any more in Southern Italy. Some of these taxa were not retrieved in the pollen record from Camerota, dated to the early Calabrian (Brenac, 1984), namely Magnolia, Nyssa, Eucommia, and 498 Symplocos. Parthenocissus was found in one level. Other taxa were lost in the Santa Lucia section, correlated 499 with MIS 43-40: Engelhardia, Sciadopitys, and Parrotia (Joannin et al., 2007b). The floristic list is substantially 500 the same at Montalbano Jonico during MIS 37 to 23, with Liquidambar, Tsuga, and Carya showing a 501 progressive decrease (Joannin et al., 2008). In the same site, during MIS 21 to 19 (858 to $745 \mathrm{ka}$ ), Liquidambar and Taxodium type are represented by sporadic grains, while Cathaya is virtually absent (Bertini et al., 2015). In the coeval site of Valle di Manche (Capraro et al., 2005), Cathaya is documented for the last time in 504 Southern Italy. During the Middle Pleistocene, the long pollen record from Vallo di Diano depicts the vegetation changes during MIS 16 to 13 (Russo Ermolli, 1994; Russo Ermolli et al., 2015). Only single grains 
of Taxodium type, Tsuga, Pterocarya, and Liquidambar were found; Cedrus, Picea, and Carya were strongly reduced but still present, especially during the interglacial phase corresponding to MIS 13. During the same forest phase, Zelkova was rather abundant, reaching percentages $>5 \%$. All these taxa disappeared from Southern Italy before the Late Pleistocene, except Picea that persisted until the last glacial maximum, as documented by the pollen record from Lago Grande di Monticchio (Allen et al., 2000; Allen and Huntley,

511 2009).

\subsection{Balkan Peninsula and Anatolia}

514 In the Balkans, several lines of information contribute to the understanding of regional Quaternary tree taxa 515 persistence and extinctions (Figs 4-5). Pollen records on long core sequences from subsiding terrestrial basins provide continuous records spanning multiple glacial-interglacial cycles, such as Lake Ohrid (Wagner et al., 2009; Sadori et al., 2016), Lake loannina (Tzedakis, 1994), Tenaghi Philippon (Tzedakis, 2006; Pross et al, 2015), and Kopais (Tzedakis, 1999, Okuda et al., 2001). Exposed geological sections, such as in the Megalopolis Basin (Okuda et al., 2002) and on Rhodes (Joannin et al., 2007a) provide discontinuous sequences that can be integrated into the wider framework through radiometric dating, palaeomagnetic and isotope stratigraphy, and correlations with astronomical cycles (Fig. 4). Pollen records from continuous marine sediment sequences also represent an important contribution, notably a 6 Ma sequence from DSDP Site 380 in the southwestern Black Sea (Biltekin, 2010; Popescu et al., 2010; Biltekin et al., 2015). Complementary information is also available from plant macrofossil locales, principally in Southwestern Greece and in the Hellenic Arc region (reviewed in Velitzelos et al., 2014).

Long-term patterns of persistence and extinction are revealed in the long, continuous pollen records. At 527 Tenaghi Philippon (Wijmstra, 1969; Wijmstra and Smit, 1976; Van der Wiel and Wijmstra, 1987a, 1987b; 528 Tzedakis et al., 2006; Fletcher et al., 2013; Pross et al., 2015), the key patterns of extinctions and their 529 relationship to glacial-interglacial cycles of the last $1.3 \mathrm{Ma}$ is discussed by Tzedakis et al. (2006). The record 530 reveals a progressive broad-scale floristic shift in forest composition, with Early Pleistocene spectra rich in 531 Castanea, Pterocarya, Carya and Cedrus replaced by assemblages with Carpinus, Ostrya and Corylus 532 alongside increased Quercus (Fig. 5). Within this transition, which occurred between 0.9 and $0.6 \mathrm{Ma}$ (and is 
associated with the first major glaciations of MIS 22 and MIS 16) a series of individual taxa disappearances is

534 recorded, with last occurrences of Liquidambar and Parthenocissus prior to MIS 22, and subsequent 535 sequential disappearance of Parrotia, Eucommia, Tsuga, Pterocarya, Carya and Cedrus (Tzedakis et al., 2006).

536 At DSDP site 380 (Popescu et al., 2010; Biltekin et al., 2015) two taxa, Avicennia and Nyssa, do not appear to 537 persist into the Middle Pleistocene at all (Fig. 5). These taxa are documented by rare occurrences in the Early 538 Pleistocene, and they appear more broadly associated with taxa whose last appearances in this sequence are 539 documented in the late Miocene and Pliocene (Arecaceae, Parrotia). Several taxa are consistently recorded 540 during the early Pleistocene, prior to around 1.2 Ma, specficially Engelhardia, Zelkova, Pterocarya and Tsuga.

541 These taxa all occur more sporadically in the middle Pleistocene sediments, and are generally absent in the 542 upper part of the sequence, corresponding to the late Middle Pleistocene and Late Pleistocene. Cathaya 543 displays a similar pattern of sporadic occurrences in the early Middle Pleistocene, although the main period 544 of consistent presence was earlier, during the Pliocene. A small group of taxa (Taxodiaceae, Carya and Cedrus) 545 are documented sporadically through the later Middle Pleistocene and Late Pleistocene.

546 At other sites with pollen records extending into the Middle Pleistocene, occasional occurrences of extinct or relictual taxa are reported. The presence of Pterocarya in mainland Greece during MIS 11 and MIS 9 is 548 confirmed in the pollen record of Kopais shown by Okuda et al., 2001. In the loannina-249 core (Tzedakis, 549 1994), Zelkova is reported in interglacials prior to the last glacial.

550 Important insights are also derived from the shorter, or discontinuous records. Subally et al. (1999) report 551 on the Coupe Citadelle, Zakynthos (2.0-1.8 Ma), where oscillations between Artemisia and Cedrus dominated 552 assemblages are associated with interglacial/glacial cycles. Alongside Cedrus, Cathaya and Taxodiaceae are 553 well represented. Joannin et al. (2007a) report findings from Early to Middle Pleistocene deposits in Rhodes 554 (Tsampika formation). Pollen diagrams for sequence TS1-3 and TS5-6 correspond to MIS 31-27 (1.1-0.98 Ma) 555 and MIS 19 ( 800-700 ka), respectively, as determined by palaeomagnetic polarity and correlation of glacial556 interglacial cycles to the marine isotope stratography. The pollen record for the earlier interval (MIS 31-27) 557 documents several mesothermic taxa no longer occurring in the regional vegetation, including Carya, 558 Zelkova, Pterocarya and Liquidambar, as well as mega-mesothermic Taxodium type and mid-altitude 
elements Tsuga and Cathaya. The record for the later interval (MIS 19) includes several of the same taxa

560 (Tsuga, Cathaya, Liquidambar, Zelkova, Carya, Pterocarya, and Taxodium type), as well as occurrences of

561 Parrotia and Hamamelidaceae pollen. It is also noteworthy that common temperate and montane taxa in 562 both intervals include Quercus and Cedrus, both of which are absent from the present day flora of Rhodes.

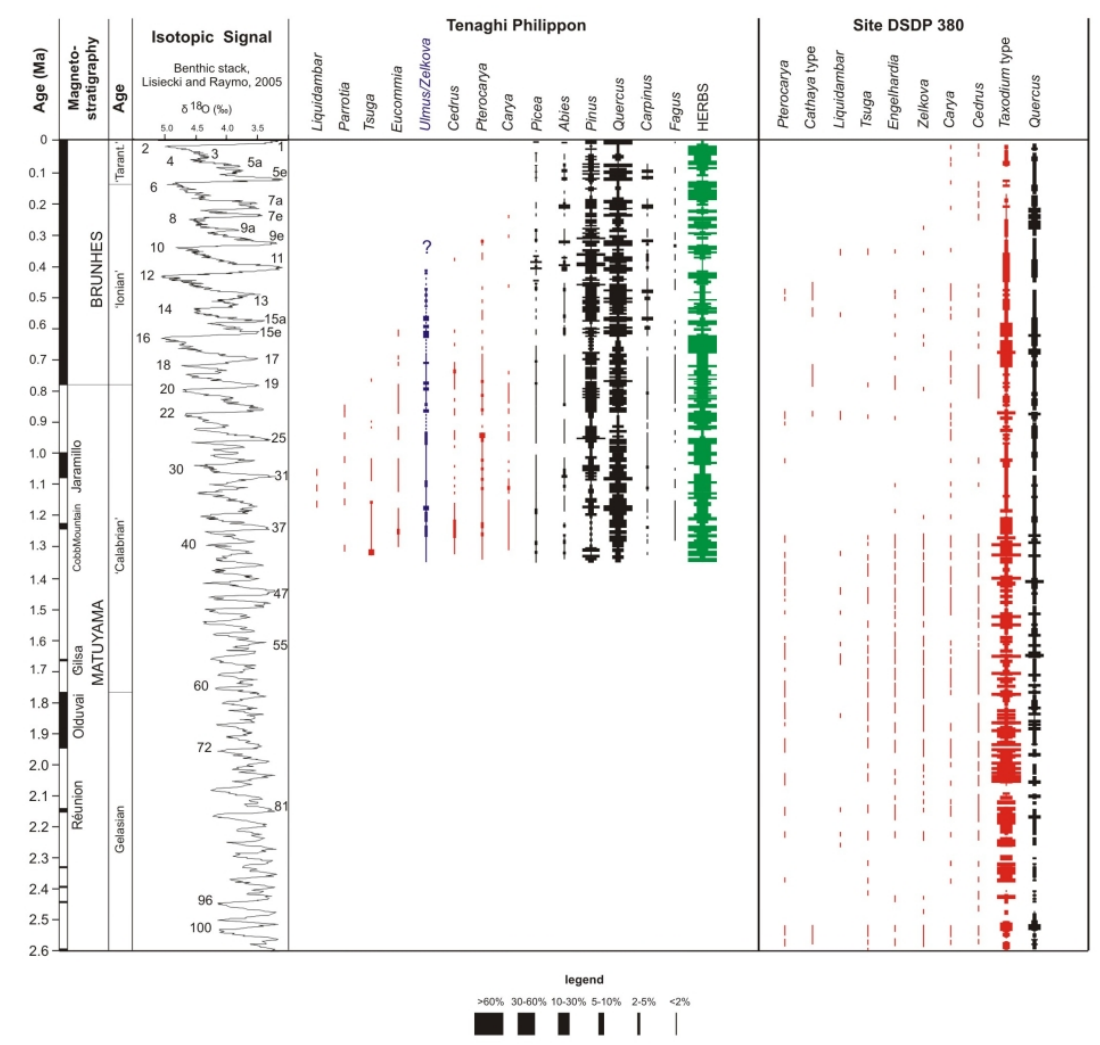

565 Fig. 5. Stratigraphical setting and schematic pollen biostratigraphy of selected taxa of Pleistocene records 566 from Tenaghi Philippon (Tzedakis et al., 2006) and DSDP site 380 (Biltekin et al. 2015). Red lines represent 567 regionally extinct taxa. Blue lines represent taxa that are only mentioned in the papers or uncertain determinations (e.g. Ulmus/Zelkova).

569 In the Megalopolis basin (Marthousa Member) in Southwestern Greece, Okuda et al. (2002) document a 570 series of Middle Pleistocene glacial-interglacial cycles with vegetation shifts between temperate forest with 571 Quercus, Acer, Carpinus and others, and steppe with Artemisia and other Asteraceae types. The sequence is 572 supported by an ESR date of $370 \pm 110 \mathrm{ka}$ and the four temperate forest phases are tentatively correlated 573 with MIS 15, 13, 11 and 9, although other possible attributions are noted (MIS 13-9, MIS 17-11). The pollen 574 diagram contains Liquidambar in the lowest temperate phase, and Pterocarya in the lower three temperate 
phases. A small sample set from exposures in the southern coastal area of the Gulf of Corinth also documents the presence of Carya, Tsuga, Cedrus, Pterocarya, Liquidambar and Zelkova, and has been used to support a Lower and Middle Pleistocene age for fluvio-lacustrine and fan-delta syn-rift deposits (Rohais et al., 2007)

Other sites have potential to contribute to the issue, but details of rare taxa, including extinct or relictual elements, may not yet be published. Sadori et al. (2016) present a new continuous pollen record spanning the last $500 \mathrm{ka}$ at Lake Ohrid, Albania. The data published to date reveals the good correspondence between 581 forested/non-forested phases and glacial-interglacial cycles, and highlights a progressive shift towards 582 warmer and drier interglacials associated with a diminishing role of Abies and Picea in the regional 583 vegetation. Future insights regarding extinct taxa for this, and the deeper sequence extending to $1.2 \mathrm{Ma}$ 584 (Wagner et al., 2009) will be important. Ongoing investigation of new boreholes at Tenaghi Philippon at high (centennial-scale) resolution may also contribute new insights into the pattern of regional extinctions in Northeastern Greece over the last 1.35 Ma (Pross et al., 2015).

\section{History of tree tree taxa extirpated from S Europe}

The compilation of the pollen records in Figs 2-5, although schematic and in many cases fragmentary, provides the basis for a comprehensive view of the population dynamics of tree taxa that disappeared from Southern Europe during the Pleistocene. In particular, they provide regional overviews of the expansions and last occurrences of the most important tree taxa that went extinct from the Southern European mainland. For this review, we selected a number of taxa that are reliably identified and appreciably represented in all the Quaternary pollen floras of South Europe: Taxodium-type, Sciadopitys, Cathaya, Cedrus, Tsuga, Eucommia, Engelhardia, Carya, Pterocarya, Parrotia, Liquidambar, and Zelkova (Figs 6-8). Other taxa, not discussed in this review, including Sapotaceae, Juglandaceae, Arecaceae, Avicennia, Aesculus, Parthenocissus, Nyssa, Picea omorika, and Platanus may deserve a further work. 


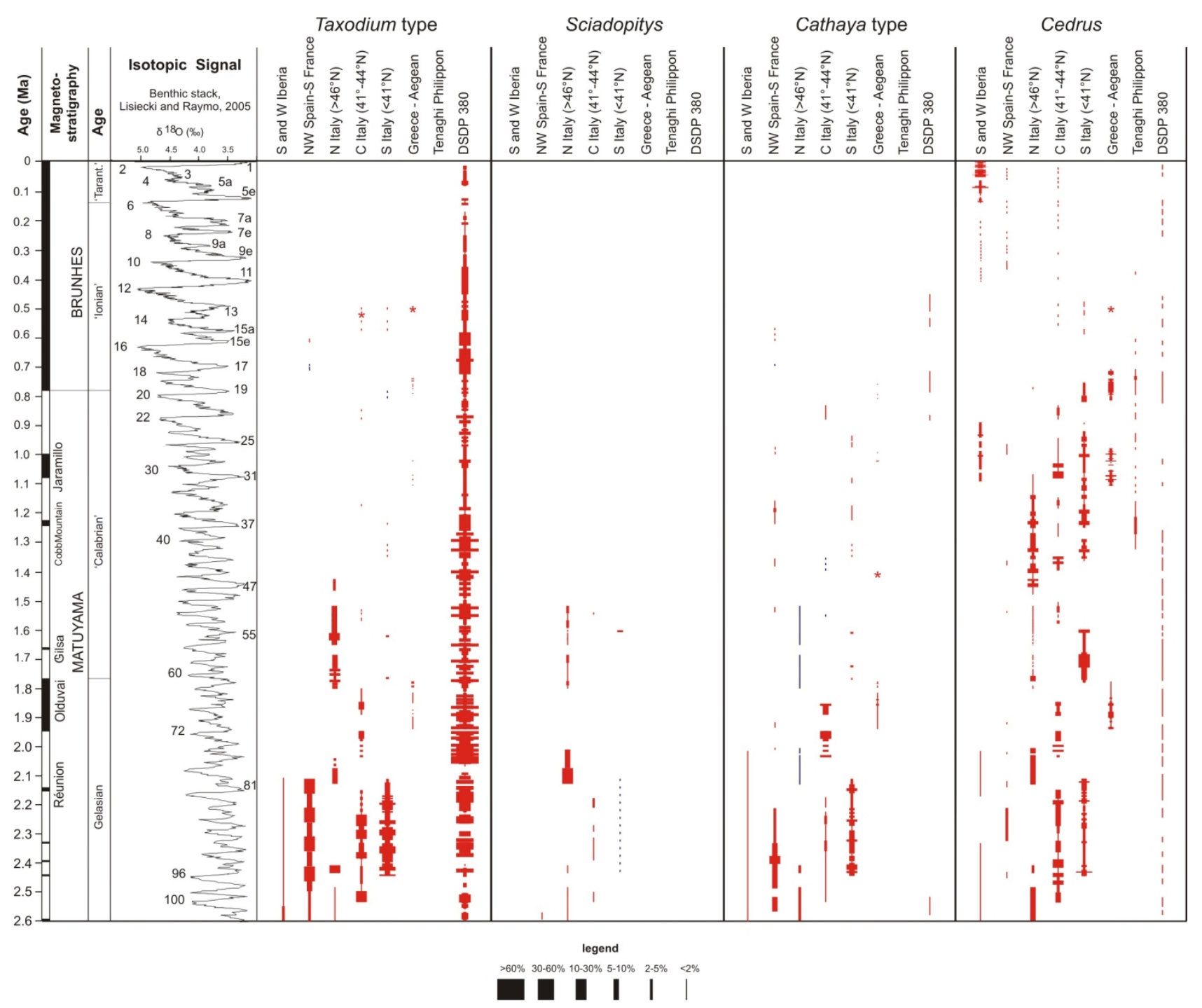

601 Fig. 6. Schematic stratigraphic distribution of Taxodium type, Sciadopitys, Cathaya type, and Cedrus. Blue 602 lines represent taxa that are only mentioned in the original papers.

\subsection{Taxodium type}

As mentioned above, the pollen types indicated as Taxodiaceae (e.g., Ravazzi, 2003; Joannin et al., 2007a,b; Biltekin et al., 2015) and Taxodium-type (e.g., Fusco, 2007; Bertini et al., 2010) may belong to different genera of the Taxoidieae subfamily (Cupressaceae family). According to Fusco (2007) and Bertini (2010), in the Italian pollen records they may include both Taxodium cf. distichum and Glyptostrobus, while Biltekin et al. (2015)

609 ascribe it mostly to Glyptostrobus. Both genera were found in the Miocene macrofossil record of Europe 610 (Kovar-Eder et al., 2006), but wood samples analyses from the Early Pleistocene deposit of Leffe (Ravazzi and 611 van der Burgh, 1995) as well as shoots, cones and seeds from the Early Pleistocene deposit of Dunarobba in 612 Central Italy (Martinetto et al., 2014) suggest that Taxodium-type pollen might be referred to Glyptostrobus. 
613 On the other hand, fossil wood from a pyroclastic deposit near Rome, Ar/Ar dated at $514 \mathrm{ka}$ (Marra et al., 614 2014), was ascribed to Taxodium (Follieri, 2010). Until more conclusive data are collected, the question of 615 the exact attribution of Taxodium/Glyptostrobus-type pollen to one or the other genus is still open, as well 616 as the possibility that more than one species or genus were present in the Quaternary deposits of Southern 617 Europe. The question is highly relevant considering the present distribution of the two genera: Taxodium is 618 limited to the southeastern regions of North America (T. distichum (L.) Rich.) and Mexico (T. huegelii 619 C.Lawson), while Glyptostrobus pensilis (Staunton ex D.Don) K.Koch (the sole extant species of this genus) 620 lives in southern China. Both Taxodium and Glyptostrobus live in swampy environments and riverbanks.

621 Bearing in mind these taxonomic uncertainties, the Pleistocene pollen records in South Europe provide a rather consistent picture of the history of Taxodium/Glyptostrobus (here after named Taxodium type) (Fig. 6). During the Gelasian, Taxodium type was present only in very low percentages in the peri-Iberian marine cores (core G1: Feddi et al., 2011), while it was rather abundant (5-10\%) in Northeastern Spain (Garraf: Suc and Cravatte, 1982), and in Italy (Stirone: Lona and Bertoldi, 1972; Fosso Bianco: Pontini and Bertini, 2000; Coste San Gacomo: Bellucci et al., 2014; Poggio Rosso: Bertini et al., 2010; Semaforo: Combourieu-Nebout, 1993). During the early Calabrian, Taxodium type was still significantly represented ( $>5 \%)$ in Northern Italy 628 (Lamone valley: Fusco, 2007; Leffe: Ravazzi, 2003). In Southern Italy it was abundant in the marine sediments 629 of the Vrica section (not shown in Fig. 6) (Combourieu-Nebout and Vergnaud-Grazzini, 1991), where it 630 progressively declined around 1.3 Ma, while it was discontinuously represented in the lacustrine sediments 631 from Camerota (Brenac, 1984). Starting in the middle Calabrian, Taxodium type was strongly reduced in the 632 Western and Central Mediterranean regions, but it still shows sporadic appearances before its final 633 disappearance, dated around 600-500 ka both in France (MIS 15 at Alleret maar: Pastre et al., 2007; Degeai 634 et al., 2013) and in Central-Southern Italy (MIS 15-13 at Vallo di Diano: Russo Ermolli, 1994; MIS 13 at Sessano: 635 Russo Ermolli et al., 2010a). Macrofossils of Taxodium from near Rome, dated around $500 \mathrm{ka}$, confirm the 636 age of these occurrences (Follieri, 2010).

637 In Greece, Taxodium-type is continuously found in low amounts at Zakynthos (Subally et al., 1999) before 1.8 638 Ma; it was sporadic at Rhodes until the early Middle Pleistocene (ca. 700 ka; Joannin et al., 2007a), where a 
639 fossil wood of Glyptostrobus is dated around 500 ka (Boyd, 2009). No record is reported from Tenaghi 640 Philippon (Wijmstra, 1969; Wijmstra and Smit, 1976; Van der Wiel and Wijmstra, 1987a,b; Tzedakis et al., 641 2006), Ohrid (Sadori et al., 2016), and Megalopolis (Okuda et al., 2002). In core DSDP 380 (Biltekin et al., 642 2015) it is abundant throughout the Quaternary until recent, but it underwent two severe declines at about $643 \quad 1.2$ and $0.5 \mathrm{Ma}$.

644 A clear pattern appears from the synoptical view of Fig. 6. The scarcity/lack of Taxodium type in Greece 645 suggests that two distinct populations/species/genera were probably present in South Europe, which had 646 different fates. The first one, found in Northeastern Spain, Southern France and Italy, underwent a severe reduction in Northeastern Spain-Southern France and Central Italy at the end of the Gelasian, persisted in Northern Italy until the mid-Calabrian (1.4-1.2 Ma), and disappeared definitely from Central and Southern Italy after ca. $500 \mathrm{ka}$. The second one was distributed in Anatolia-Rhodes; it underwent a first severe reduction around 1.2 $\mathrm{Ma}$ and a second reduction around $500 \mathrm{ka}$ (at approximately the same age of the last occurrence in Italy), but was in any case able to survive until recent times.

\subsection{Sciadopitys}

The sole extant species of the family Sciadopityaceae is Sciadopitys verticillata (Thunb.) Siebold \& Zucc.

Molecular dating shows that it represents one of the earliest diverging plant lineages (ca. $220 \mathrm{Ma}$ ) survived by a single species in the world alongside other classic 'living fossils' such as Ginkgo (Worth et al., 2013). It is currently patchily distributed in high rainfall montane areas of Japan (islands of Honshu, Shikoku and Kyushu) within temperate forests, where mean annual precipitation can exceed 4000 mm/yr (Farjon, 2005). It was found in several Pliocene sites in Northwestern Europe (Kemna and Westerhoff, 2007), France (Suc, 1973), and Northern Italy (Pini et al., 2003). The pollen data from Southern Europe (Fig. 6) indicate that, apart from

661 a single find in the marine core G1 from the Alboran Sea (Feddi et al., 2011), the only country where it is recorded is Italy, where it is found not only during the Gelasian (Stirone: Lona and Bertoldi, 1972; Bertini, 2001; Fosso Bianco: Pontini and Bertini, 2000; Semaforo: Combourieu-Nebout, 1993; Klotz et al., 2006), but 

Calabrian age, but they are considered reworked from underlying Early Pliocene marine clays (Leroy et al., 667 1994).

668 No occurrences of Sciadopitys are reported from Greece the Aegean islands and DSDP site 380, indicating 669 that the genus may have disappeared from Southeastern Europe in the course of the Pliocene, as it was 670 present in upper Miocene sediments from Samos and in Lower Pliocene deposits of Ptolemaida, in Western 671 Macedonia, as documented by macrofossils (Velitzelos et al., 2014).

672 The comparative view of the pollen records from Southern Europe has provided novel information about the 673 past distribution of this taxon, which has considerable evolutionary interest. In particular, Italy appears as a long-term refuge area for Sciadopitys, that persisted in several areas of the Italian Peninsula for over one million years after it had disappeared from the rest of Europe. This long-term persistence might be connected with generally high rainfall along the Italian mountain chains.

\subsection{Cathaya}

Cathaya is a monotypic genus of the Pinaceae family, presently living only in Southeastern China, in mesophilous forests at 900-1900 m elevation (Farjon, 2008). It is categorised as a palaeoendemic, with a fossil history dating at least to the Cretaceous (Liu and Basinger, 2000). Pollen of Cathaya has often been misidentified, having been confused with Pinus haploxylon-type, or even Podocarpus (Liu and Basinger, 2000). In many European records, it is named Cathaya type, leaving a certain margin of error. This is because many determinations of fossil grains are based on published photographs and descriptions (Caratini and Sivak, 1972; Sivak, 1976; Liu and Basinger, 2000; Zanni and Ravazzi, 2007), and not on fresh reference collections, due to the rarity of the single extant species, Cathaya argyrophylla, which was formally described only in 1958 by Chun and Kuang. In several Early Pleistocene Italian sites its pollen has been often classified as, or joined to Pinus haploxylon-type (Capraro et al., 2005; Fusco, 2007; see photographs in Lona and 
Cathaya fossils were found in many Miocene and Pliocene sites in Europe as both macrofossils (Kovar-Eder 691 et al., 2006; Velitzelos et al., 2014) and pollen (Jiménez-Moreno and Suc, 2007; Popescu et al., 2010). During 692 the early Gelasian, Cathaya was continuously present in the marine record from the Alboran Sea (Feddi et 693 al., 2011), and abundant (even >10\%) in the record from Garraf 1 in Northeastern Spain (Suc and Cravatte, 694 1982). All the fragmented records from Northeastern Spain-Southern France of Early Pleistocene age reveal 695 its presence until at least the Jaramillo subchron, although in minimal amounts. In Northern Italy, it was well 696 represented at Stirone, in the Gelasian (Bertini, 2001). It was still present at the beginning of the Calabrian 697 at the Lamone Valley, where it is grouped together with Pinus haploxylon (Fusco, 2007), then it was not any 698 more found (Ravazzi, 2005). In Central Italy, Cathaya was again well represented during the Gelasian, with 699 percentages in some cases reaching values of 10\% (Pontini and Bertini, 2000; Bertini et al., 2010; Bellucci et 700 al., 2014), while in the Calabrian it is recorded (as Pinus haploxylon) in two sites (Gubbio and Pietrafitta), 701 whose age - not well constrained - is around 1.4 Ma (Lona and Ricciardi, 1961; Lona and Bertoldi, 1972). Its 702 last occurrence is at Fontana Ranuccio in an interglacial phase dated around 850 ka (Corrado and Magri, 703 2011). In Southern Italy, Cathaya was abundant in the Early Pleistocene marine record of Crotone especially 704 from ca. 1920 ka to $1740 \mathrm{ka}$; then it decreased but was still present around 1.3 Ma (Combourieu-Nebout and 705 Vergnaud- Grazzini, 1991). Small amounts of Cathaya pollen are found in Southern Italy until approx. 750 ka 706 (Capraro et al., 2005; Joannin et al., 2007b, 2008). In Greece, Cathaya is well represented in the Gelasian 707 record from Zakinthos (Subally et al., 1999), it is represented by macrofossils finds of Calabrian age at Rhodes 708 (Mai and Velitzelos, 2007; Velitzelos et al., 2014), while it is not recorded at Tenaghi Philippon, where it could 709 have been counted as Pinus haploxylon-type, almost continuously present up to 850 ka (Wijmstra and Smit, 710 1976; Van der Wiel and Wijmstra, 1987a). Cathaya pollen is rare in the Early Pleistocene record at the DSDP 711380 site (Biltekin et al., 2015).

712 During the Middle Pleistocene, only two sites report sporadic occurrences of Cathaya in Southern Europe: 713 Alleret in Southern France at 700-550 ka (Pastre et al., 2007; Degeai et al., 2013) and Site 380, discontinuously 714 present until $380 \mathrm{ka}$ (Biltekin et al., 2015). 

records provide a consistent picture of the history of Cathaya, which was present at all sites during the

717 Gelasian. In the Calabrian it was probably more common in Southern Italy (Combourieu-Nebout and

718 Vergnaud- Grazzini, 1991) than in other regions, where it was already severely fragmented. However, the sparse occurrences documented in France and Anatolia between 700 ka and 380 ka suggest that very small relict populations may have persisted in isolated location and warn of the possibility to find more fossil remains of Middle Pleistocene age in Southern European deposits.

\subsection{Cedrus}

The genus Cedrus includes two extant accepted species, native in the Mediterranean mountains: Cedrus atlantica (Endl.) Manetti ex Carrière, living in Algeria and Morocco (Slimani et al., 2014), and Cedrus libani A.Rich., distributed in Asia Minor (Fady et al., 2008), including Cedrus libani var. brevifolia Hook.f. in Cyprus, sometimes considered as a separate species (Jasińska et al., 2013). A further species, Cedrus deodara (Roxb. ex D.Don) G.Don, lives in Afghanistan and in the southern slopes of the western Himalaya (Bou DagherKharrat et al., 2007). The modern Mediterranean populations of Cedrus are severely fragmented as a result of the unfavorable climate conditions of the last glacial period (Cheddadi et al., 2009), of a long history of human activity (Hajar et al., 2010b), and of increasing aridity in the late Holocene (Hajar et al., 2010a). indicate its presence near the site (Hajar et al., 2010a; Bell and Fletcher, 2016). This result is confirmed by the Holocene pollen records from Morocco, Algeria and Lebanon, showing high ( $>10 \%)$ pollen percentages of Cedrus in the vicinity of modern cedar forests (Lamb et al., 1989; Hajar et al., 2008; Cheddadi et al., 2009). For this reason, sparse pollen grains of Cedrus that are often found in late Quaternary sedimentary deposits from the north Mediterranean regions, especially during the last glacial period (Magri and Parra, 2002), have been interpreted as the effect of long-distance transportation from north Africa (Reille, 1990). 
741 (Jiménez-Moreno et al., 2008). However, in the course of the Pleistocene, Cedrus underwent a strong 742 reduction, disappearing from Europe, where it is currently absent. It is worth noticing that a strong reduction 743 of Cedrus has been reported in also China since the Upper Pliocene, and ascribed to an intensification of the 744 East Asian winter monsoon (Su et al., 2013).

745 The Southern European pollen records (Fig. 6) document a regionally diverse history of Cedrus. In the marine 746 sediment cores from the Alboran sea, Cedrus had a discontinuous presence at the end of the Pliocene and 747 during the Gelasian (Feddi et al., 2011), while continuous and appreciable percentages of Cedrus pollen are 748 found during the time intervals ca. 1.09-0.90 Ma (core ODP976: Joannin et al., 2011), 48-26 ka (core MD95749 2043: Sánchez-Goñi et al., 2002), and the last 25 ka (core ODP976: Combourieu-Nebout et al., 2009). These records support a continuous presence of cedar throughout the Pleistocene in the regions facing the Alboran 751 sea, with a most likely North African origin of this anemophilous pollen type, also considering the documented presence of Cedrus in Morocco during the late Middle Pleistocene (Benzú rockshelter: Ramos et al., 2008) and the Late Pleistocene (Lamb et al., 1989; Cheddadi et al., 2009).

The Early Pleistocene record from the Iberian Peninsula documents only sporadic occurrences of Cedrus, except for the Gelasian record from Garraf 1 (Suc and Cravatte, 1982). Pollen of Cedrus was very rare or absent at Morgadinho in Algarve (Antunes et al., 1986), at Tres Pins (Leroy, 1997), Banyoles (Julia Bruguès and Suc, 1980), Cal Guardiola D2 (Postigo Mijarra et al., 2007), and Bòbila Ordis IV (Leroy, 2008). In Southern 758 France, Cedrus was found in various deposits of Pliocene age (Fauquette et al., 1999; Suc and Drivaliari, 1991), 759 but in the Early Pleistocene it was recorded in very low amounts at Senèze (Elhaï, 1969), Bernasso (Leroy and 760 Roiron, 1996), Nogaret (Leroy and Seret, 1992), Saint Macaire (Leroy et al., 1994), and Ceyssac-8 (Ablin, 761 1991). By contrast, the Early Pleistocene record of Cedrus from the Italian Peninsula is very rich. In Northern 762 Italy, where it was abundant already during the Pliocene (Aulla: Bertoldi, 1988; Stirone: Bertini, 2001), pollen 763 percentages $>5 \%$ document its local presence at Stirone (Lona and Bertoldi, 1972; Bertini, 2001), Lamone 764 Valley (Fusco, 2007), and Leffe (Ravazzi and Rossignol-Strick, 1995; Ravazzi, 2003; Muttoni et al., 2007). It 765 becomes sporadic in the Prealps at the end of the Early Pleistocene (Fornaci di Ranica: Ravazzi et al., 2005). 766 In Central Italy, Cedrus is well represented in several Pliocene sites (e.g., Upper Valdarno Basin: Bertini and 
Roiron, 1997; Bertini and Martinetto, 2011; Borgorose and Marano de' Marsi: Sadori et al., 2010), and also

many Early Pleistocene sites document abundant pollen of cedar, with values in some levels $>10 \%$ at Fosso

Bianco (Pontini and Bertini, 2000), Coste San Giacomo (Bellucci et al., 2014), Gubbio (Lona and Ricciardi, 1961) and Colle Curti (Bertini, 2000). In some late Early Pleistocene (Calabrian) sites Cedrus was present but sparse (Madonna della Strada: Magri et al., 2010; Pagliare di Sassa: Palombo et al., 2010; Saticula: Russo Ermolli et al., 2010b; Fontana Ranuccio: Corrado and Magri, 2011), suggesting that its distribution was already rather fragmented in Central Italy. Also in Southern Italy, Cedrus was already present in the Pliocene together with other montane conifers (Cathaya, Tsuga, Abies, and Picea) (Punta Piccola: Combourieu-Nebout et al., 2004). In the Early Pleistocene it was abundant in the marine sediments at Semaforo-Vrica (Combourieu-Nebout and Vergnaud-Grazzini, 1991; Combourieu-Nebout, 1993), Camerota (Brenac, 1984), Santa Lucia (Joannin et al., 2007b), and Montalbano Jonico (Joannin et al., 2008). Marine sediments from Rhodes (Joannin et al., 2007a) show a continuous presence of Cedrus in the island in the Early Pleistocene, with values much higher than at Tenaghi Philippon (Tzedakis et al., 2006) and at Site 380 (Biltekin et al., 2015), where it was rather discontinuous.

During the Middle and late Pleistocene the French sites in the Velay region document a very discontinuous occurrence of Cedrus (Reille et al., 2000, Pastre et al., 2007; Degeai et al., 2013). In the Iberian Peninsula, 783 Cedrus is relatively frequent in continental pollen records during the Late Pleistocene and Holocene, although 784 with percentages values never >2\% (see compilation by González-Sampériz et al. (2010) and references 785 therein, as well as the recent pollen record from Cañizar de Villarquemado: González-Sampériz et al., 2013; 786 Aranbarri et al., 2014; García-Prieto, 2015). In Italy, Cedrus underwent a dramatic reduction during the Middle Pleistocene, being recorded in significant amounts only in Southern Italy at the Early to Midlle Pleistocene transition (Bertini et al., 2015; Capraro et al., 2005). In Northern Italy it was absent in the early Middle Pleistocene (Pianico Sèllere: Moscariello et al., 2000; Ravazzi, 2003) and was not found until present 790 (see Azzano Decimo: Pini et al., 2009, Fimon: Pini et al., 2010). In Central and Southern Italy the record of 791 Cedrus was disontinuous at all sites during the Middle and Late Pleistocene (Cesi: Bertini, 2000; Torre 792 Mucchia: Pieruccini et al., 2016; La Pineta: Lebreton, 2002; Ceprano: Manzi et al., 2010; Sessano, Russo 793 Ermolli et al., 2010a; Vallo di Diano: Russo Ermolli, 1994; Acerno: Munno et al., 2001; Boiano, Orain et al., 
2015; Valle di Castiglione: Follieri et al., 1988; Lagaccione: Magri, 1999; Lago Grande di Monticchio: Allen et al., 2000). Unexpectedly, Cedrus is well represented (>2\%) in the lateglacial record from Pesce Luna (Di Rita et al., 2015) near Rome. In the Balkan Peninsula, the Middle Pleistocene records from Ohrid (Sadori et al., 2016), Ioannina (Tzedakis, 1994; Roucoux et al., 2008), Megalopolis (Okuda et al., 2002) and Kopais (Okuda et al., 2001) do not document a presence of Cedrus in the region. It is also possible that these diagrams, representing only selected taxa, do not report occasional finds of Cedrus, whose presence must have been negligible. At Tenaghi Philippon (Tzedakis et al., 2006) during the Middle Pleistocene Cedrus became sporadic until its last occurrence, dated approx. 0.35 Ma. In the marine record from Rhodes (Joannin et al., 2007a), which is relatively close to the modern range of Cedrus in Turkey, it is found with frequencies $>20 \%$ in forest phases of the early Middle Pleistocene correlated to MIS 19 and 17. Interestingly, fossil leaves of Cedrus were found in Rhodes in sediments with an age of about $0.5 \mathrm{Ma}$, confirming the local presence of the genus until at least the Middle Pleistocene (Boyd, 2009). In the Black Sea, Cedrus is continuously documented until recent, although with discontinuous occurrences, suggesting its long-time persistence on the mountain areas bordering the Anatolian Plateau and its elimination from the northern and western margins of the Black Sea by human disturbance (Biltekin et al., 2015).

The interpretation of the Southern European pollen record of Cedrus is not totally conclusive: while it is clear that it was widespread in Italy and in the Aegean region during the Early Pleistocene, as documented by high 811 pollen percentage values, it is very difficult to evaluate the discontinuous single grains found in the Iberian, 812 French and Italian records since the Middle Pleistocene. Following the interpretation by Postigo-Mijarra et 813 al. (2010) who consider that even sparse occurrences of Cedrus indicate its local presence, Cedrus should 814 have been present in Southern Europe until the Holocene. Alternatively, supporting the hypothesis by Reille 815 et al. (2000) and Magri and Parra (2002) that sparse pollen grains are of North African origin, Cedrus was never present in continental Iberia during the Quaternary, disappeared from Northeastern Spain-Southern 817 France at the beginning of the Pleistocene, and from the Italian Peninsula at an early stage of the Middle 818 Pleistocene. In Greece, Cedrus possibly persisted a little longer, but the continuous record from Tenaghi 819 Philippon indicates that during the last 1.4 Ma it was always rather sparse. The almost continuous presence 820 of Cedrus in the Black Sea core is consistent with its relative vicinity in Turkey. 


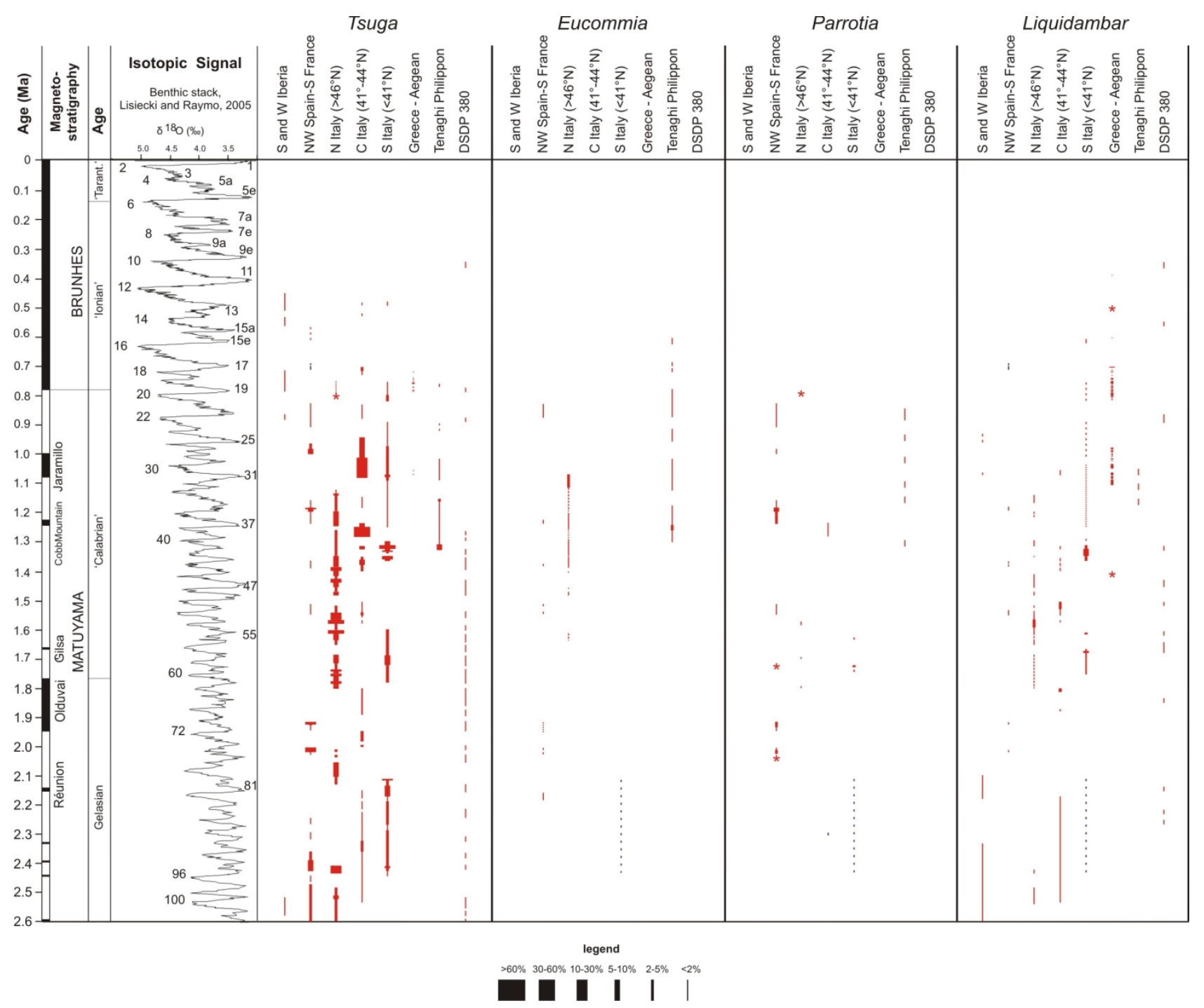

822 Fig. 7. Schematic stratigraphic distribution of Tsuga, Eucommia, Parrotia, and Liquidambar. Blue lines 823 represent taxa that are only mentioned in the original papers.

826 The genus Tsuga (Pinaceae) is an important element of subalpine coniferous and temperate broad-leaved 827 deciduous forests, currently showing a disjunct distribution in Eastern and Western North America, Japan, 828 China and Himalaya. It lives at elevations from sea level to $3800 \mathrm{~m}$, in areas where precipitation ranges from 829700 to $4500 \mathrm{~mm} /$ year and is distributed throughout the year (Farjon, 2008). An abundant fossil record of 830 Tsuga indicates that it was distributed throughout North America and Eurasia from the Late Cretaceous to 831 the Plio-Pleistocene (LePage, 2003). In the Northwestern European records of Early Pleistocene age, Tsuga 832 pollen is found during the Tiglian (MIS 79-63), Waalian (MIS 49-37) and Bavelian (MIS 31-22) (Zagwijn, 1985). 
833 The last occurrence of Tsuga pollen grains in Central Europe is during the Leerdam interglacial, a post834 Jaramillo late Early Pleistocene warm stage (Zagwijn and De Jong, 1984).

835 During the Gelasian, Tsuga is well represented at all sites in Northeastern Spain-Southern France and in Italy 836 (Fig. 7), including Garraf (Suc and Cravatte, 1982), Bernasso (Leroy and Roiron, 1996), Nogaret (Leroy and 837 Suc, 1992), Stirone (Lona and Bertoldi, 1972; Bertini, 2001), Fosso Bianco (Pontini and Bertini, 2000), Coste 838 San Giacomo (Bellucci et al., 2014), Poggio Rosso (Bertini et al., 2010), Semaforo and Vrica (Combourieu839 Nebout, 1993; Combourieu-Nebout and Vergnaud-Grazzini, 1991). In contrast, it is not represented in the 840 marine records south of $38^{\circ} \mathrm{N}$ from the Alboran Sea (G1: Feddi et al., 2011) and from Zakynthos (Subally et 841 al., 2009). In core DSDP 380 it is discontinuously represented.

842 The Calabrian record of Tsuga is generally very rich, showing higher percentages than in the Gelasian, at least 843 until the Jaramillo subchron. In Northeastern Spain it is particularly abundant at Bòbila-Ordis IV (Leroy, 2008) 844 and and S France at Ceyssac-8 (Ablin, 1991). It is also present with values $>10 \%$ in Southwestern France in 845 the Médoc region (O'Brien and Jones, 2003), reflecting the fact that it was largely distributed over Southern 846 Europe. In Northern Italy it was found with percentages often $>10 \%$ at the Lamone Valley (Fusco, 2007), Leffe 847 (Ravazzi and Rossignol Strick, 1995; Ravazzi, 2003), Pianengo (Muttoni et al., 2003), and in the late Early 848 Pleistocene lacustrine sediments from Fornaci di Ranica (Ravazzi et al., 2005). It was also found in Slovenia 849 near Novo Mesto (Šercelj, 1961) and near Ilirska Bistrica (Šercelj, 1965). In Central Italy it was abundant in 850 many sites, reaching its highest percentages ( $>30 \%$ ) at Madonna della Strada (Magri et al., 2010) around 1.3 851 Ma and at Colle Curti (>10\%) during the Jaramillo subchron (Bertini, 2000). It was continuously present also 852 in the records of Pietrafitta (Lona and Bertoldi, 1972), Gubbio (Lona and Ricciardi, 1961), Leonessa (Ricciardi, 853 1965), Saticula (Russo Ermolli et al., 2010b), and Fontana Ranuccio (Corrado and Magri, 2011). In Southern 854 Italy it is very abundant in the marine sediments (>30\%) at Santa Lucia during MIS $43-40$ (Joannin et al., 855 2007b) and is continuously present at Montalbano Jonico during MIS 37 to 23 (Joannin at al., 2008). At 856 Tenaghi Philippon in Macedonia (Tzedakis et al, 2006), Tsuga displays declining percentages in the interval 857 1.35-0.8 Ma. In Site 308 its declining trend is very evident, as it becomes sporadic after 1.27 Ma (Biltekin et 858 al., 2015). 
During the Middle Pleistocene, Tsuga underwent a marked general decline, although with different timings

860 from one region to the other. There are very few data from Spain that can help to assess the local presence 861 of Tsuga. In Southern France, there were still sporadic occurrences in two interglacial periods corresponding 862 to MIS 17 and MIS 15 at the Alleret maar (Pastre et al., 2007; Degeai et al., 2013). In Northern Italy, the 863 lacustrine succession of Pianico-Sèllere (Moscariello et al., 2000), close to the Early/Middle Pleistocene 864 boundary (Pinti et al., 2001), records only sporadic grains of Tsuga (Ravazzi at al., 2005), which correspond 865 to the last occurrences for this taxon in Northern Italy. However, macrofossil finds are reported at the site of 866 Oriolo dated around 800 ka (Martinetto and Sami, 2001). In Central Italy, Tsuga was still found with percentages $>3 \%$ in an early interglacial phase correlated with MIS 17 (Pieruccini et al., 2016), and with single pollen grains in the early Middle Pleistocene (Cesi: Bertini, 2000), and during MIS 13 (Sessano: Russo Ermolli at al., 2010). In Southerrn Italy, Tsuga was still well represented (2-5\%) at the Early to Middle Pleistocene transition (Valle di Manche: Capraro et al., 2005; Montalbano Jonico: Bertini et al., 2015), but was dubitably present during MIS 13 (Vallo di Diano Russo Ermolli, 1994). However, it was virtually absent from some sites (Lebreton, 2002), suggesting that its distribution was rather patchy. In the Aegean, the last occurrences of Tsuga date back to MIS 17 (Joannin et al., 2007), slightly later than at Tenaghi Philippon, where it disappears near the Brunhes/Matuyama transition (Tzedakis et al. 2006). At Lake Ohrid, located at the border between the Former Yugoslavian Republic of Macedonia and Albania, although the detailed record has not been published yet, the occurrence of Tsuga is reported with an age younger than 500 ka (Sadori et al., 2016). At Site 380 Tsuga is sporadically found until 230 ka (Biltekin et al., 2015).

Considered altogether, the Southern European Quaternary records of Tsuga appear rather homogenous (Fig. 7), with sparse presence in the most southern sites (Alboran Sea, Rhodes), and significant abundances in 880 Northeastern Spain-Southern France and the Italian Peninsula during the Early Pleistocene, especially during 881 the Calabrian. A general increase in Tsuga, recorded between 1.8 $\mathrm{Ma}$ and $1 \mathrm{Ma}$, is often considered indicative of cooler but relatively moist conditions (Bertini, 2010). From the population dynamics point of view, it is noteworthy that this general expansion of Tsuga during the Calabrian, corresponding also to a significant presence in central Europe, occurred just before its decline, which was moderate until approx. 700 ka, and 
diappearance. This is recorded at different times: approx. $750 \mathrm{ka}$ in Northern Italy, $550 \mathrm{ka}$ in Southern France, and 280 ka in Anatolia. In the light of the most recently published data from several Middle Pleistocene sites, 888 and considering the under-representation of Tsuga pollen (Janssen, 1984), the single pollen grains found at 889 Vallo di Diano (Russo Ermolli, 1994) may be considered representative of local small stands of Tsuga, so fixing 890 around 450 ka the age of the last occurrence of Tsuga in Southern Itay.

891 Bertini (2000) related the disappearance of Tsuga to the Middle Pleistocene shift from 41 to 100 ka cyclicity, 892 leading to increased global aridity and decreased temperatures during the glacial stages, whereas Ravazzi et 893 al. (2005) ascribed the Tsuga decline recorded at Fornaci di Ranica to catastrophic fires triggered by summer 894 drought.

\subsection{Eucommia}

Eucommia ulmoides Oliv. is the single extant species of the genus Eucommia (Eucommiaceae). It is a small deciduous tree currently living only in a hilly area of South China (Wang et al., 2003). It is more tolerant of dry climate than many other extinct genera (Svenning, 2003), although spring temperature is a limiting factor for Eucommia (Wang et al., 2003).

901 It was present in Central Europe during the Pliocene (Hably and Kvacek, 1998), where it was found until the 902 late Early Pleistocene (Ber, 2005).

903 With respect to Southern Europe, Eucommia pollen was not found in the marine cores from the Alboran Sea, 904 where it was missing also in Pliocene sediments (Feddi et al., 2011). In contrast, it is found in almost all sites 905 in Northeastern Spain and Southern France, until the end of the Early Pleistocene (ca. 800 ka), suggesting a 906 local persistence in the area. The Middle Pleistocene records from the Alleret Maar (700-550 ka) do not 907 report Eucommia any more (Pastre et al., 2007; Degeai et al., 2013).

908 In Italy, pollen of Eucommia was present in the Gelasian marine sediments from Semaforo, but its record is 909 not shown in detail in the original papers (Combourieu-Nebout, 1993; Klotz et al., 2006). It is missing from all 910 the Pleistocene pollen records from Central Italy. It is discontinuously documented in Northern Italy during 911 the early Calabrian (Fusco, 2007), but increased in the course of time, reaching its highest values at the 
912 Jaramillo subchron (Ravazzi, 2003; Muttoni et al., 2007). Macrofossils of Eucommia were found in the

913 Castelletto Cervo II site, of possible Gelasian age (Cavallo and Martinetto, 2001), at Arda-Castell'Arquato both

914 in Gelasian and in late Calabrian layers (Martinetto, 2015; Martinetto et al., 2015), as well as in the latest

915 Calabrian (Stirone-Laurano site: Gregor, 1986). The consistency of pollen and macrofossil data supports the

916 hypothesis advanced by Martinetto (2015) of an Early Pleistocene immigration or increase of Eucommia in

917 Northern Italy. In Italy, Eucommia is not recorded after the Calabrian.

918 Eucommia is not present in the Aegean records, while it is recorded at Tenaghi Philippon from the base of 919 the record up to approx. 600 ka (Tzedakis et al., 2006). In Site 380 it is found only in Pliocene sediments 920 (Popescu et al., 2010).

921 The history of Eucommia is clearly distinct from the other taxa that disappeared from Europe during the 922 Quaternary, as this temperate tree persisted in central Europe at least as long as in Southern France, until 923 the late Calabrian. It expanded in Northern Italy during the Early Pleistocene, without reaching Central Italy, 924 where it was never found. The population at Tenaghi Philippon was possibly a separate one, as it is not 925 matched by any other data from Greece and around the Black Sea.

\subsection{Parrotia}

928 The genus Parrotia (family Hamamelidaceae) includes two species: P. persica C.A. Mey., endemic to the 929 Alborz Mountains of northern Iran (Sefidi et al., 2011), and P. subaequalis (Hung T. Chang) R.M. Hao \& H.T. 930 Wei, endemic to a restricted area in Eastern China (Li and Del Tredici, 2008). The disjunct distribution and the 931 relictual state of the genus reflect the dramatic reduction it underwent during the Pleistocene.

932 The European records of Miocene and Pliocene age indicate that Parrotia was widespread, together with 933 other genera currently restricted in the Hyrcanian region, including Pterocarya and Zelkova (Jiménez-Moreno 934 and Suc 2007; Jiménez-Moreno et al., 2008, 2010).

935 The Pleistocene records of Parrotia in Southern Europe are sparse (Fig. 7), probably because its pollen is 936 markedly under-represented, as shown in the Early Pleistocene site of Bernasso, where a large number of 
937 fossil leaves (at least 130 specimens; $15 \%$ of total finds) are matched by only low pollen percentages (max 938 4\%) (Leroy and Roiron, 1996). Pollen morphology is illustrated in Leroy (2007) and Bińka et al. (2003).

939 During the Early Pleistocene, Parrotia is recorded in all Southern European regions (Spain; Southern France;

940 North, Central and Southern Italy; and Northeastern Greece at Tenaghi Philippon), and even in IODP Site 941 U1385 off Portugal, dated around 1.26 Ma (Tzedakis et al., 2015). Macrofossils were found in the Iberian 942 Peninsula at Crespià-Incarcal (Villalta and Vicente,1972; Roiron, 1983) and in France at Bernasso (Leroy and 943 Roiron, 1996).

944 The last record of Parrotia in Southern Europe comes from Northern Italy at the onset of the Middle 945 Pleistocene, where it is represented by fossil leaves (Martinetto and Sami, 2001). The record by Bottema 946 (1974), who reported up to 10\% Parrotia in loannina-II core, is very uncertain, as Parrotia was not found 947 again at loannina in any part of the $423 \mathrm{kyr} \mathrm{I-249} \mathrm{sequence} \mathrm{(Tzedakis,} \mathrm{1994),} \mathrm{nor} \mathrm{in} \mathrm{the} \mathrm{stratigraphically} \mathrm{longer}$ 948 I-284 sequence (Lawson et al., 2004), nor in the Ohrid core, spanning the last 500 ka (Sadori et al., 2016).

949 In Southern Europe, the lack of fossil remains of Parrotia younger than ca. 800 ka is surprising, also in the 950 light of its continuous record during an interglacial phase attributed to the Holsteinian in Eastern Poland 951 (Bińka et al., 2003). Various explanations may be suggested to solve this puzzle: either it had a long-term 952 refuge in Central Europe, or it migrated there from Southern Europe but it was never found there due to its 953 poor pollen dispersal, or it reached Eastern Poland from the Caspian region, where it is still documented by 954 Holocene pollen records (Leroy et al., 2013), passing north of the Caucasus Range. The latter hypothesis is 955 also supported by the absence of Parrotia from the Southwestern side of the Black Sea since the Pliocene 956 (Biltekin et al., 2015).

\subsection{Liquidambar}

959 The genus Liquidambar (family Altingiaceae) is distributed over a wide geographical range extending from 960 North America to East Asia. In the Mediterranean basin, it is represented only by the species L. orientalis 961 Mill., naturally distributed in the temperate parts of Western and Southern Anatolia and on the island of 
962

963

Rhodes (Öztürk et al., 2008). It prefers the wet-mild bioclimate of moist bottomlands, occasionally flooded swampy plains, riparian habitats and humid areas.

It was a rather common component of mixed deciduous and evergreen forests in Europe during the Miocene and Pliocene, being often an element of a riparian vegetation, accompanied by Salix, Alnus, Carya, Pterocarya, Carpinus, Zelkova, and Ulmus (Jiménez-Moreno and Suc 2007; Jiménez-Moreno et al., 2008, 2010).

Liquidambar is recorded in the Early Pleistocene marine cores from the Alboran Sea up to 900 ka (Feddi et al., 2011; Joannin et al., 2011) and in the records from Spain until the Jaramillo subchrone (Fig. 7). In the Massif central it was present during MIS 17 (Degeai et al., 2013), while it was no longer found in the sediments corresponding to MIS 15 (Pastre et al., 2007).

In Northern and Central Italy, Liquidambar is documented in the Calabrian sediments of the Lamone valley (Fusco, 2007), Leffe (Ravazzi and Rossignol-Strick, 1995; Ravazzi, 2003), Gubbio (Lona and Ricciardi, 1961), Pietrafitta (Lona and Bertoldi, 1972), and Colle Curti (Bertini, 2000), while it is missing in all the Middle Pleistocene sites. In Southern Italy, Liquidambar was almost continuously present until 1.3 Ma (Joannin et al., 2007), was rather discontinuous until 900 ka (Joannin et al., 2008), and represented by sparse pollen grains at the Early to Middle Pleistocene transition (Capraro et al., 2005; Bertini et al., 2015). The pollen record from Vallo di Diano documents Liquidambar around 600 ka (Russo Ermolli, 1994). This find was considered reworked, but in the light of the most recent papers recording Liquidambar around 750 ka in Southern Italy (Bertini et al., 2015) and 700 ka in France (Degeai et al., 2013), as well as the last occurrence of Liquidambar at Tenaghi Philippon around 480 ka (Wijmstra and Smit, 1976; Van der Wiel and Wijmstra, 1987a, 1987b), it may be reasonably regarded as valid.

A significant presence in the Middle Pleistocene pollen records (Joannin et al., 2007), as well as macrofossil finds (Boyd, 2009; Velitzelos et al., 2014) from Rhodes are not surprising, considering the small population of Liquidambar currently living in the island. At Site 380, an almost continuous presence until $1.28 \mathrm{Ma}$ and disappearance at $270 \mathrm{ka}$ are revealed by the pollen record.

The recent pollen studies from Southern Europe and Anatolia allow the definition of a marked decline of Liquidambar populations in Europe towards the end of the Early Pleistocene. During the Middle Pleistocene 
its remnant populations were scattered in various regions (Southern France, Southern Italy, coasts of the

990 Black Sea), but still surviving for a few glacial/interglacial cycles before being reduced to the small polulations

991 currently living in Rhodes and Southeastern Turkey.

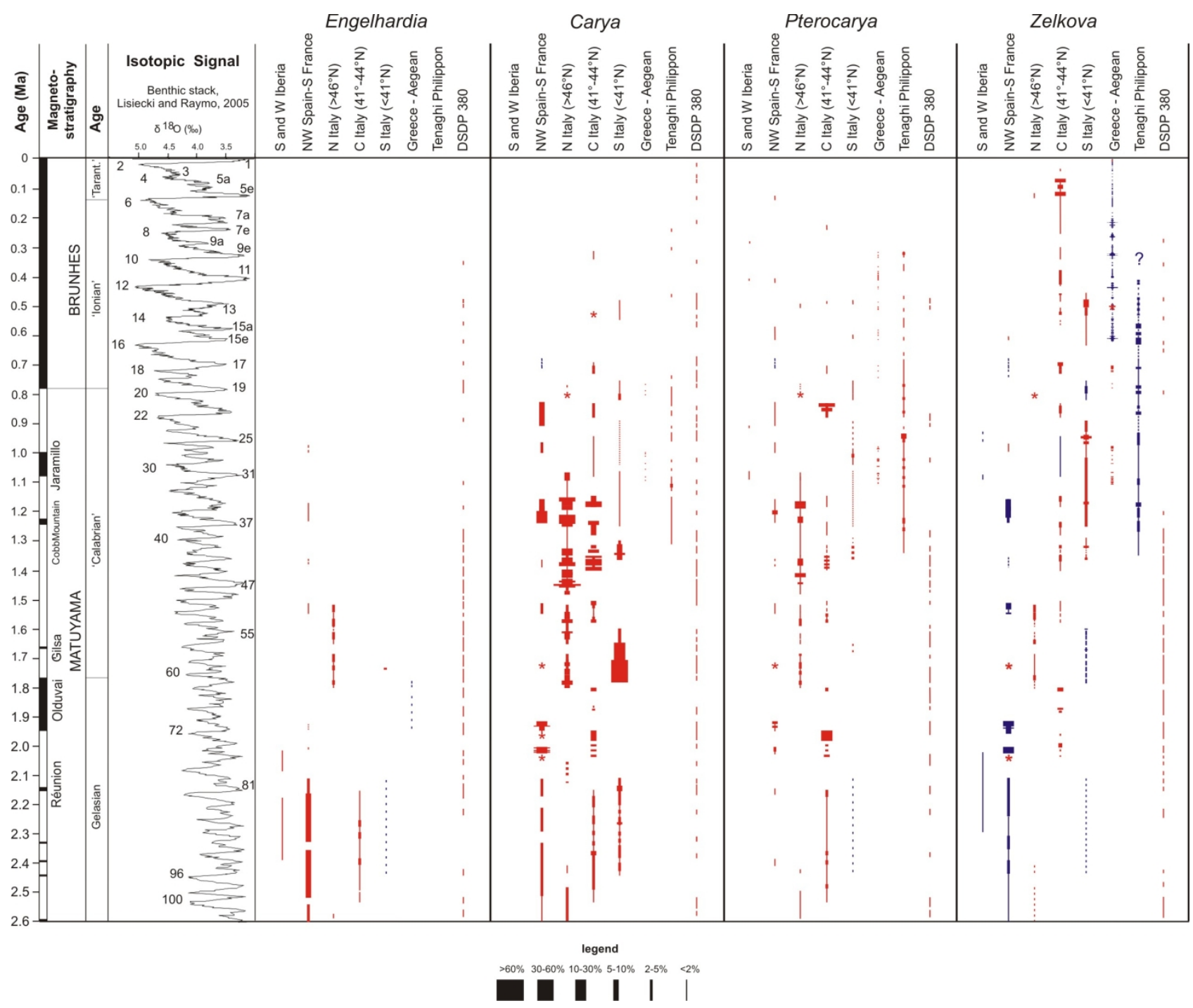

993 Fig. 8 Schematic stratigraphic distribution of Engelhardia, Carya, Pterocarya, and Zelkova. Blue lines 994 represent taxa that are only mentioned in the original papers.

4.9 Engelhardia

997 Engelhardia is a genus of the family Juglandaceae currently widespread in tropical to subtropical forests of 998 South China, Indochina, Malaysia, Philippines and New Guinea, with mean annual precipitation between 740 999 and 3500 mm (Fang et al., 2011; Meng et al., 2015). It was very common in European Miocene and Pliocene 
deposits, where it was found both as macrofossils and pollen (e.g., Ivanov et al., 2002; Kovar-Eder et al., 2006;

1001 Jiménez-Moreno and Suc, 2007; Jiménez-Moreno et al., 2008; Velitzelos et al., 2014).

1002 The genus shows an extinction pattern during the Pliocene with decreasing ages from North to South Europe,

1003 in relation with the Northern Hemisphere temperature evolution, with a longer persistence in the

1004 Mediterranean regions where it probably disappeared because of increasing dryness (Popescu et al., 2010;

1005 Biltekin et al., 2015).

1006 During the Gelasian, it was recorded in low amounts in the marine core G1 from the Alboran Sea (Feddi et 1007 al., 2011), and abundantly (up to 10\%) in the site of Garraf (Suc and Cravatte, 1982; Fauquette at al., 1998, 1008 González-Sampériz et al., 2010), in continuity with its Pliocene distribution (Fig. 8). At Fosso Bianco in 1009 Southern Italy (Pontini and Bertini, 2000), it is also in continuity with the Pliocene record, but it shows much 1010 lower percentages $(<5 \%)$. In Northern Italy it only shows a sporadic occurrence in the Stirone section, where 1011 it was continuously present during the Pliocene (Bertini, 2001). Engelhardia is reported in Southern Italy at 1012 Semaforo, but its presence was probably modest, as it is not shown separately from other elements of the 1013 Subtropical humid forest, altogether showing percentages always <5\% (Combourieu-Nebout, 1993; Klotz et 1014 al., 2006). It is reported from Rhodes up to $1.7 \mathrm{Ma}$ ( Biltekin et al., 2015), and is present in Site 380 (Biltekin 1015 et al., 2015), although discontinuously.

1016 In the Calabrian, Engelhardia appears strongly reduced in Spain and Southern France, where it was anyway 1017 found in several sites until approx. 1 Ma (Ablin, 1991; Leroy et al., 1994; Leroy, 2007, 2008). In Italy it is 1018 recorded both in Northern Italy (Lamone Valley: Fusco, 2007) and in Southern Italy (Camerota: Brenac, 1984). 1019 It was possibly present also in the Vrica section: detailed data have not been published (Combourieu-Nebout 1020 and Vergnaud-Grazzini, 1991), but its last occurrence at Vrica is reported at $1.35 \mathrm{Ma}$ by Biltekin et al. (2015). 1021 Interestingly, Engelhardia was not found in any site of Central Italy, nor in the records from Greece and the 1022 Aegean, while at Site 380 it was relatively abundant until $1.25 \mathrm{Ma}$, then it is sporadic (Biltekin et al., 2015).

1023 In the Middle Pleistocene, Engelhardia was not found in Spain, France and Italy. Sporadic finds at the Early 1024 to Middle Pleistocene transition in Southern Italy (Capraro et al., 2005; Bertini et al., 2015) are considered as 1025 reworked (Bertini, 2015). However, it is reported from a Mid-Pleistocene core from the North Adriatic Sea 
1026 (unpublished report: Biltekin et al., 2015), and it is represented by sporadic occurrences at Site 380 until ca. 1027200 ka (Biltekin et al., 2015). Interestingly, it was found further East in the Western Caucasus in the early 1028 Middle Pleistocene (Shatilova et al., 2011).

1029 The Quaternary history of Engelhardia in Southern Europe shows a marked fragmentation pattern since the 1030 end of the Pliocene, when Engelhardia was distributed over large parts of the European territory. It persisted 1031 longer in Northeastern Spain/Southern France (until ca. $1 \mathrm{Ma}$ ) than in the Italian Peninsula, where it was 1032 probably split into two separate populations: one in Southern Italy, persisting until approx. 1.35 Ma (or 1033 possibly later if the finds at the Early to Middle Pleistocene transition will be confirmed), and one in Northern 1034 Italy, lasting until the early Calabrian, separated by a large region in Central Italy where Engelhardia was 1035 absent. A separate population, lasting until ca. $200 \mathrm{ka}$, is documented by the long DSDP 380 record in the 1036 Black Sea.

1039 The genus Carya (family Juglandaceae) is currently distributed in subtropical and temperate continental 1040 biomes over North America in the United States, Canada and Mexico, and Southeast Asia in China, Viet Nam, 1041 Laos and India, with rainfall values between 1000 and 1500 mm/year (Manchester, 1987; Fang et al., 2011; 1042 Orain et al., 2013). It was rather common in central Europe during the Miocene and Pliocene (Pontini and 1043 Bertini, 2000; Jiménez-Moreno et al., 2008, 2010; Kovar-Eder et al., 2006).

1044 In the Gelasian Southern European record (Fig. 8), Carya is well represented at all sites, except the peri1045 Iberian marine cores, where it is absent. In Site 380 it is almost continuously represented, although in very 1046 low frequencies.

1047 Towards the end of the Gelasian and during the Calabrian, there was a general increase in pollen percentage 1048 values of Carya, in some cases surpassing 30\%. In the late Gelasian French sites of Nogaret (Brugal et al., 1049 1990; Leroy and Suc, 1992) and Bernasso (Leroy and Roiron, 1996), high percentages of Carya pollen (up to $105035 \%$ ) and macrofossils document its dominance in the local vegetation. A large number of macrofossils were 1051 found by Martinetto (2015) in Italy. At all sites in Italy, Carya is one of the main elements of the forest 
1052 vegetation during the early Calabrian (Russo Ermolli, 2010b). Apparently, this considerable expansion of

1053 Carya forests ended first in Southern Italy, with percentages being always $<5 \%$ since ca. 1.25 Ma (Joannin et 1054 al., 2008), then in Central Italy, where low frequencies are found since approx. $1.1 \mathrm{ka}$ at the beginning of the 1055 Jaramillo subchrone (Bertini, 2000), and soon after in Northern Italy (Ravazzi, 2003; Muttoni et al., 2007). In 1056 Northeastern Iberia, Carya was still well represented at the Early to Middle Pleistocene transition (Banyoles: 1057 Geurts, 1979). At Tenaghi Philippon and at Site 380, Carya was always present in low amounts during the 1058 Early Pleistocene.

1059 The last occurences of Carya in S Europe are recorded during the Middle Pleistocene. In France, it was 1060 recorded at the Alleret maar between 700 and 550 ka (Pastre et al., 2007; Degeai et al., 2013), but it was not 1061 any more present in the Praclaux interglacial, correlated with MIS 11 (Reille et al., 2000). An unpublished 1062 record of Carya (Suc et al., in progress) identified in Southern France up to the Last Glacial (Biltekin et al., 1063 2015) needs to be better documented.

1064 Macrofossils of Carya, reported from the site of Oriolo in N Italy (ca. 800 ka; Martinetto and Sami, 2001), 1065 more or less coeval to the last finds of Carya pollen at Pianico Sèllere (Rossi, 2003; Ravazzi et al., 2005; 2008), 1066 agree with pollen data from the magnetostratigraphically dated Venice core sediments (Müllenders et al., 1067 1996). In Central and Southern Italy, Carya was still locally present at Torre Mucchia (Pieruccini et al., 2016) 1068 at the onset of the Middle Pleistocene, as well as at various sites during the forest phase corresponding to 1069 MIS 15 and 13 (Vallo di Diano: Russo Ermolli, 1994; Ceprano: Manzi et al., 2010), as also confirmed by a 1070 macrofossil find at Carsoli (Sadori et al., 2010). However at the same time it was absent from a number of 1071 other sites, for example at La Pineta before MIS 15 (Lebreton, 2002) and at Sessano before MIS 13 (Russo 1072 Ermolli et al., 2010a,b), as well as at Acerno during MIS 13 (Petrosino et al., 2014), probably because its 1073 distribution was already rather fragmented. Its last occurrence in the Italian Peninsula is recorded at Boiano 1074 (Orain et al., 2013), a site that is administratively located in Southern Italy, but in this paper included Central 1075 Italy because it located at a latitude $>41^{\circ} \mathrm{N}$ (Figs 4 and 7). Its persistence in the Boiano basin may be linked 1076 to specific local physiographical characters enhancing humid climate conditions, that may have favored the 1077 establishment of a vegetation refuge (Orain et al., 2013). At Tenaghi Philippon, Carya shows an almost 
1078

1079

1080

1081

1082

1083

1084 A few remarks can be made on the Pleistocene history of Carya in Southern Europe. First of all, the studies 1085 carried out in the last few years have considerably delayed the age of the last occurrence of Carya, both in 1086 1087 1088 1089 1090

continuous record until the Early to Middle Pleistocene transition, then it presents only sporadic occurrences until 200 ka (Tzedakis et al., 2006). A Middle Pleistocene presence of Carya in the Balkan peninsula is also confirmed by its occurrence at in the 500,000 years old record from Lake Ohrid, for which detailed pollen data have not been published yet (Sadori et al., 2016). In the Black Sea core DSDP 380, Carya is discontinuously recorded until the Holocene (ca. $2 \mathrm{ka}$ ), which is the most recent occurrence in Europe and the Near East (Biltekin et al., 2015). the Italian Peninsula (MIS 9) and in Anatolia (Holocene). New published data are expected for Southern France and Northeastern Spain to define the age of its disappearance. A second observation is that, as also shown for Tsuga, Carya populations were very vigoruous before their final decline in the Middle Pleistocene and did not show any sign preluding to the impending extirpation. Interestingly, dense populations lasted longer in regions (Southern France and Northern Italy) where they disappeared first. In Central and Southern Italy, as well as at Tenaghi Philippon, they decreased sooner, but lasted longer. So, while Carya-dominated forests ended in the eastern and southern regions of Southern Europe earlier than the Northwestern Mediterranean areas, the opposite is true for the last occurrences of Carya pollen.

\subsection{Pterocarya}

The genus Pterocarya (family Juglandaceae) has at present a disjunct distribution, with several species living in both the western and eastern regions of the Asiatic continent. The species with the distribution closest to Europe is Pterocarya fraxinifolia (Poir.) Spach, living in Caucasus and in the Hyrcanian forests and extending further west along the Black Sea, with extrazonal populations in S Turkey and in the Zagros Mts (Akhani and Salimian, 2003). It currently populates flooded forests and valleys with running water, often in association with Alnus glutinosa (Akhani et al., 2010; Sheykholislami and Ahmadi, 2009).

Pterocarya was a constituent of evergreen and deciduous mixed forest in Europe, with other riverine taxa, during the Miocene and Pliocene (Jiménez-Moreno et al., 2008, 2010; Popescu et al., 2010). During the 
1104 Pleistocene it was found in Northwestern and Central Europe in interglacial phases, until the Holsteinian

1105 (generally correlated with MIS 11), for which period Pterocarya is often considered a characteristic taxon 1106 (Bińka et al., 2003).

1107 In Southern Europe, it is found in most records (Fig. 8), generally in very low frequencies (<2\%), but in some 1108 sites it is very abundant, attaining >25\% at the Gelasian site of Coste San Giacomo (Bellucci et al., 2014), >10\% 1109 at Leffe (Ravazzi, 2003), $>60 \%$ at Fontana Ranuccio (Corrado and Magri, 2011) in the Calabrian, and $>50 \%$ in 1110 the Middle Pleistocene site of Riano (Follieri, 1962), where also fossil fruits and leaves were recovered 1111 (Follieri, 1958). This uneven behavior suggests that the abundance of Pterocarya was more related to local 1112 hydrological regimes (e.g., flooding), than to general climatic conditions, according to its modern ecological 1113 requirements.

1114 As to the timing of its disappearance, Pterocarya became rare in Anatolia by $1.26 \mathrm{Ma}$ and was recorded 1115 around $400 \mathrm{ka}$ for the last time (Biltekin et al., 2015). In Greece, it was present at Tenaghi Philippon (Tzedakis 1116 et al., 2006) and Kopais (Okuda et al., 2001) until MIS 9 (approx. 320 ka). In Central Italy it was found at Valle 1117 di Castiglione (Follieri et al. 1988) until MIS 7 (ca. 200 ka). In the French Massif Central it is reported until MIS 111811 (Reille et al. 2000), but traces are found also in MIS 9 (M. Reille, pers. commun., in Tzedakis et al., 2006). 1119 The same age is assigned to a pollen record from the French Alps, where Pterocarya attains 10\% (Field et al., 1120 2003). Pterocarya is recorded in two marine cores off Portugal: MD01-2447 during MIS 11 (ca. 400 ka Desprat 1121 et al., 2005) and MD03-2697 during MIS 9 (ca. 298 ka: Desprat et al., 2009). In continental Spain, isolated 1122 grains of Pterocarya were observed in the lowest part of the Cañizar de Villarquemado sequence, attributed 1123 to MIS 5 (González-Sampériz et al., 2013; García-Prieto, 2015). This is the first time that Ptercarya pollen 1124 grains are found in European sequences during the Late Pleistocene. However, since the study is still in 1125 progress, it must be taken with caution.

1126 Summing up this information, Pterocarya was more or less present at all European sites with different 1127 densities, depending on the local situation, until $400 \mathrm{ka}$, after which time its distribution was severely 1128 fragmented causing its disappearance at different times until its last recorded occurrence during, probably, 1129 the Eemian (ca. $120 \mathrm{ka}$ ). 


\section{4.12. Zelkova}

1132 The genus Zelkova (family Ulmaceae) includes three extant species living in East Asia, one in the Caucasus 1133 and nearby mountain ranges in Turkey and Iran (Z. carpinifolia (Pall.) K. Koch), one in Crete (Z. abelicea (Lam.) 1134 Boiss.), and one in Sicily (Z. sicula Di Pasq., Garfi \& Quézel) (Denk and Grimm, 2005). Its modern distribution 1135 is therefore disjunct and is subject to a progressive reduction (Kozlowski et al., 2012), above all in its south1136 western Eurasian species, which have haplotypes that are distinctly clustered according to species 1137 assignment (Christie et al., 2014).

1138 One major problem concerning the fossil record of Zelkova is the difficulty of identifying its pollen. 1139 Morphological differences with Ulmus are found in the ectexine, especially for its marked sculpture and the 1140 thickening around the pores, in the number of pores (mostly 4), and in the sub-quadrangular to square (if 41141 porate) shape of pollen grains (Kuprianova, 1965; Follieri et al., 1986; Nakagawa et al., 1998; Kvavadze and 1142 Connor, 2005). In many publications, Ulmus and Zelkova pollen types have been lumped together. 1143 Nonetheless, we have taken these records into consideration and represented them (in blue) in Figs 2-5 and 11448.

1145 The Pleistocene records from Spain are not conclusive about the regional history of Zelkova, as in most cases

1146 its pollen was not counted separately from Ulmus. However, the local presence of Zelkova in Northeastern 1147 Iberia is documented in the leaf flora of the Early Pleistocene site of Incarcal at Crespià (Roiron, 1983). During 1148 the Middle and Late Pleistocene it is not recorded in Spain any more. In Southern France, during the Gelasian 1149 Zelkova is found in the pollen record from Senèze in the Massif Central (Elhaï, 1969), and in the leaf flora 1150 from Nogaret and Bernasso (Leroy and Seret, 1992; Leroy and Roiron, 1996). It is documented in the late 1151 Early Pleistocene record of Ceyssac-8 (Ablin, 1991) and in the Middle Pleistocene sediments from the Alleret 1152 maar (Pastre et al., 2007; Degeai et al., 2013), which attest the last occurrence of Zelkova in France during 1153 MIS 15.

1154 In Italy, Zelkova shows discontinuous presence in Northern Italy, where well preserved macrofossil finds are 1155 reported from Oriolo around $800 \mathrm{ka}$ (Martinetto and Sami, 2001). The last pollen occurrences in Northern 
1156 Italy are reported from the Southeastern Po Plain (Amorosi et al., 2004) and Venice (Müllenders et al., 1996)

1157 during the Eemian intergacial (ca. $120 \mathrm{ka}$ ). In Central and Southern Italy, modest but continuous presence of 1158 Zelkova is documented throughout the Pleistocene, until its disappearance. Only a few expansions show 1159 frequencies around 10\% (Fig. 8): at the end of the Calabrian at Santa Lucia (Joannin et al., 2008), during MIS 116013 at Vallo di Diano (Russo Ermolli et al., 2015), at Riano in a forest phase probably corresponding to MIS 11, 1161 where also macrofossils of Zelkova were found (Follieri, 1958, 1962), and during the Eemian interglacial at 1162 Valle di Castiglione near Rome (Follieri et al., 1986, 1988). The last occurrence of Zelkova in the Italian 1163 Peninsula is documented in the open forest phases corresponding to MIS 3 (somewhat older than $30 \mathrm{ka}$ ) at 1164 three sites of the Lazio region: Valle di Castiglione (Follieri et al., 1986, 1988), Lago di Vico (Magri and Sadori, 1165 1999), and Lagaccione (Magri, 1999). Such late occurrence of Zelkova is supported by the relatively near 1166 location of two modern populations of Z. sicula in Sicily (Garfi et al., 2011).

1167 Zelkova is recorded in Rhodes by both pollen and macrofossils until approx. 500 ka (Joannin et al., 2007a; 1168 Boyd, 2009). After this time there are no other pollen records available for the area that can attest the age 1169 of its disappearance. At Tenaghi Philippon, Ulmus/Zelkova is documented until $420 \mathrm{ka}$ (Van der Wiel and 1170 Wijmstra, 1987a). It is also mentioned as present in the 500 ka-old record from Lake Ohrid (Sadori et al., 1171 2016). Zelkova was found during the Eemian interglacial (ca. 120 ka) at loannina (Tzedakis et al., 2003). In 1172 Southern Greece Ulmus/Zelkova is recorded between 650 and 300 ka at Megalopolis (Okuda et al., 2002), 1173 and between 500 ka to recent at Kopais (Okuda et al., 2001). This late record is corroborated by the 1174 occurrence of Zelkova between 4 and $3 \mathrm{ka}$ in the Gulf of Corinth (Fouache et al., 2005) and by the populations 1175 of Z. abelicea still living in Crete (Kozlowski et al., 2014).

1176 In Site 380, Zelkova is continuously recorded up to $1.22 \mathrm{Ma}$ and sporadically up to 150 ka (Biltekin et al., 1177 2015), an age that is consistent with the modern presence of Z. carpinifolia in the nearby Western 1178 Transcaucasia (Kozlowski et al., 2012).

1179 On the whole, the fossil records from Southern Europe, together with the biogeographical and genetic data 1180 available for the extant species, form a fairly accurate reconstruction of the history of Zelkova in S Europe, 1181 except for the Iberian Peninsula, where either Zelkova disappeared very early compared to the other 
1182 European regions, or the scanty fossil record available for the Middle Pleistocene has failed to trace its

1183 presence. In Italy, in Greece and in the Black Sea, the existence of relatively close population of relict species

1184 strongly support the pollen finds dating back to the Late Pleistocene/Holocene.

\section{Timing and trends of tree population extinctions}

1187 The wealth of data available from the Early and Middle Pleistocene pollen records of S Europe allows

1188 discussion of several aspects of long-term dynamics of tree populations, related to the reduction and 1189 extinction of species.

1190 A first observation concerns the general changes of the vegetation in which the extinction processes are

1191 framed. Figs 2-5 show that in the course of the Pleistocene there was a progressive decrease in forest 1192 vegetation and a corresponding increase in herbaceous and steppe environments. This is especially evident 1193 in the peri-Iberian marine records, in Northeastern Spain-Southern France and in Central-Southern Italy. In

1194 Northern Italy, apart from a time interval of a few hundred thousand years during the Calabrian with 1195 relatively high values of herbs, herbaceous vegetation was never dominant. Even during the glacial periods, 1196 Pinus was widespread. In Greece and the Aegean, including Tenaghi Philippon, the general decrease in 1197 forestation is less evident, as the vegetation appears rather open already in the Early Pleistocene. At Site 380, 1198 a progressive decline of trees appears related to the decline of Taxodium populations, as Quercus does not 1199 show significant changes in abundance along the Pleistocene.

1200 This overall decline of forest vegetation in the Mediterranean region, paralleling the amplitude of Pleistocene 1201 climatic cycles, has been observed and discussed by several authors (Suc and Popescu, 2005; Fusco, 2007; 1202 Popescu et al., 2010, Bertini, 2010, Magri and Palombo, 2013). Since the onset of the Pleistocene, 40 ka 1203 obliquity-forced glacial-interglacial cycles led to the alternation of forest vegetation and steppes in many 1204 sites of the Mediterranean Basin, although the direct correlation of steppe phases with glacial periods is a 1205 controverse matter (Capraro et al., 2005; Bertini, 2010). This climate cyclicity determined a strong reduction 1206 of the Pliocene sub-tropical forests, which required high temperatures and precipitation throughout the year, 1207 and led to a corresponding increase in oak-dominated vegetation, with conifer forests at high altitudes 
1208 (Combourieu-Nebout et al., 2015). A further shift toward a more extended periodicity and amplitude of 1209 glacial interglacial cycles, from 41 ka to approximately $100 \mathrm{ka}$, provoked a further decline of forests and an 1210 overall spread of steppe conditions during the so-called Mid-Pleistocene Revolution (MPR), which occurred -

1211 in its broadest definition - between 1.2 and $0.5 \mathrm{Ma}$ (Head and Gibbard, 2005). During this transition, 1212 important changes were observed in the European vegetation (Suc and Popescu, 2005; Tzedakis et al., 2006; 1213 González-Sampériz et al., 2010; Leroy et al., 2011; Combourieu-Nebout et al., 2015), also driving changes in 1214 faunal communities of both large (Kahlke et al., 2011; Magri and Palombo, 2013) and small mammals (van 1215 Kolfschoten and Markova, 2005).

1216 Climate reconstructions based on selected pollen records from southern Italy suggest a general decline in 1217 winter temperature and annual precipitation from the Early Pleistocene to the Holocene, with main changes 1218 around $2 \mathrm{Ma}, 1.4-1.3 \mathrm{Ma}$ and $0.5 \mathrm{Ma}$ (Combourieu-Nebout et al., 2015). Latitudinal and longitudinal 1219 gradients were observed by Suc and Popescu (2005) and Combourieu-Nebout et al. (2015), who detected a 1220 progressive disappearance of thermophilous vegetation mostly from North to South. In addition, the Asiatic 1221 monsoon enhanced a longitudinal temperature gradient favouring the preservation of thermophilous 1222 elements in the eastern Mediterranean areas (Suc and Popescu, 2005). This important reduction in moisture 1223 availability and/or the increase in seasonal drought intensity may also be a major factor causing the general 1224 reduction of a type of habitat that was originally widely distributed in the Mediterranean, namely flooded 1225 ground habitats and damp woodland, populated by swamp vegetation, which are currently restricted to 1226 limited areas, also following the extensive reclamation works undertaken during the last centuries.

1227 Despite these general vegetational trends in relation to longitudinal and latitudinal gradients, the 1228 composition of vegetation in S Europe during the Pleistocene shows significant regional differences, 1229 reflecting a mosaic of geographic and climatic situations and partly anticipating the modern complexity of 1230 vegetation patterns (Figs 2-5).

1231 In the marine cores off Portugal and Spain the dominant element was always Pinus, usually associated to its 1232 over-representation in marine sediments, despite inner continental sequences also show important values 1233 of this conifer (Carrión (Ed.), 2012). In the early Pleistocene, the abundance of oaks together with Olea is 
1234 remarkable, as well as the surprising abundance of Fagus since the late Early Pleistocene (Joannin et al., 1235 2011).

1236 In Northeastern Spain-Southern France, two clear turnovers of dominant vegetation types can be observed: 1237 during the Gelasian, forests dominated by subtropical elements, including Symplocos, Engelhardia, Taxodium 1238 type and Cathaya type, were replaced by a vegetation dominated by Tsuga, Picea, Carya, Pterocarya, Quercus 1239 and Carpinus, and increasing frequencies of Abies, in turn substituted by Quercus, Picea, Abies, Carpinus and 1240 increasing Fagus during the Early to Middle Pleistocene transition. Pinus was abundant throughout.

1241 In Northern Italy, conifers were dominant during the Gelasian, including Sciadopitys, Taxodium type, Tsuga, 1242 Cedrus, Picea, and Abies, together with Juglandaceae (Carya, Pterocarya, and Juglans). This forest 1243 composition persisted with little changes throughout most of the Calabrian, with only one important 1244 turnover at the onset of the Middle Pleistocene. This apparently rapid change may also be an effect of the 1245 fragmentary character of the available records. The Middle Pleistocene vegetation appears much 1246 impoverished, and dominated by Pinus, Picea, Abies, Quercus, Carpinus and Fagus.

1247 In Central Italy, a sequence of four main vegetation types is evident: (i) during the first half of the Gelasian, 1248 forests were dominated by Taxodium type, Cedrus, Picea, Quercus, and Carya, accompanied by typical 1249 Pliocene taxa, such as Engelhardia, Nyssa and Sciadopitys; (ii) in the second half of the Gelasian, the 1250 vegetational landscape was dominated by Cathaya, Taxodium type, Cedrus, Carya, Tsuga and Quercus; (iii) 1251 in the Calabrian, first Carya and then Tsuga were the dominant trees, in forests with abundant Cedrus, Picea, 1252 and Quercus; (iv) starting in the Middle Pleistocene, Abies, Quercus, Carpinus, and Fagus increased and 1253 alternately characterized the forest phases. Pinus was always abundant.

1254 In Southern Italy, the succession of vegetation types is similar to Central Italy, but with a clear reduction of 1255 Liquidambar, Tsuga and Carya during the mid-Calabrian, when forests become dominated by Cedrus, 1256 Quercus and Zelkova. Besides, Picea was much less abundant than in Central Italy. During the Middle 1257 Pleistocene, forests were characterized by Quercus, Abies, and Carpinus, and then also by Fagus, increasing 1258 around 0.5 Ma. 
In Greece and the Aegean, the dominant elements of forest vegetation were Pinus, Quercus and Abies

1260 throughout the Quaternary, with significant amount of Cedrus and Liquidambar during the Calabrian.

1261 At Tenaghi Philippon, Quercus was largely dominant since the Early Pleistocene, accompanied by Pinus and 1262 significant percentages only of Tsuga, Pterocarya and Cedrus in the Early Pleistocene, and Picea and Abies in 1263 the Middle Pleistocene.

1264 In Site 380, Taxodiaceae was predominant, declining through time, while Quercus dominated the Quaternary 1265 vegetation.

1266 It clearly appears that it is not possible to identify dominant vegetation types and events of vegetation 1267 turnover valid across Southern Europe that can characterize the single chronostratigraphic units of the 1268 Quaternary. The composite pollen diagrams of Figs 2-5 may constitute reference biostratigraphical schemes 1269 only at a regional scale.

1270 Another important aspect emerging from the long composite pollen records is that several tree genera 1271 persisted regionally from the beginning of the Quaternary until the late Pleistocene. They include: Quercus 1272 and Pinus in all regions; Picea, Carpinus and Fagus in all regions except Greece and Site 380, where they are 1273 rare; Taxodium and Carya only in site 380. Recognizing the long-term persistence of tree populations and 1274 their demographic history through multiple glacial-interglacial cycles may be especially important to 1275 determine the timing of the genetic diversification of modern tree populations (Magri, 2010). Interestingly, 1276 recent papers have advanced hypotheses on the timing of genetic divergence in tree populations that are 1277 consistent with the timing of possible bottlenecks, as reconstructed by long pollen records. Bagnoli et al. 1278 (2016), exploring the genetic structure of Quercus cerris, suggest that the divergence of its Anatolian and 1279 Balkan populations occurred at the beginning of the Gelasian, at the same time as a dramatic reduction in 1280 oaks, followed by a new population increase, observed at Site 380 . The same correspondence between the 1281 timing of genetic differentiation and demographic history of plant populations may be recognized in the 1282 populations of Abies in Central-Southern Italy, which were found to have diverged from the northern 1283 populations around $600 \mathrm{ka}$ (Piotti et al., 2016). It is intriguing that the fossil record indicates that the 1284 populations of Abies in Central-Southern Italy show a vigorous expansion at approx. $600 \mathrm{ka}$, after a period of 
over one million years with only modest percentages (Figs 3 and 4), suggesting that the observed expansion 1286 was possibly related to the spread of a new, probably genetically different, population.

1287 The demographic history of tree populations at the timescale of the whole Quaternary may open new 1288 perspectives on the extinction of tree taxa. In fact, rather unexpectedly, several trees that underwent 1289 extinction in Southern Europe show widespread diffusion and considerable abundance before their 1290 disappearance. For example, Carya and Tsuga markedly expanded during the late Early Pleistocene, to a 1291 degree that provides no indication of their impending extirpation during the Middle Pleistocene. Zelkova 1292 displays frequencies around 10\% during the Eemian interglacial in Central Italy, only a few tens of thousands 1293 of years before its last occurrence during the last glacial period. However, other taxa persist in small and 1294 sparse populations before their final decline. This is the case of Cathaya type, Liquidambar, and Taxodium/Glyptostrobus that are found in many pollen records with single occurrences for hundreds of thousands of years before their last occurrence. In synthesis, it appears that the duration of the extinction process is very variable from one taxon to the other, or from one population to the other.

1298 The timing of extinction of tree taxa in Southern Europe (Figs 6-8) appears very diverse from one region to 1299 the other. In some cases, there are differences of hundreds of thousands of years even between regions close 1300 to each other. For example, Cathaya is not found in Northern Italy after 1.5 Ma, while it persists in Southern 1301 France until approx. 600 ka. Eucommia lived in Northern Italy until 1.1 Ma, but it probably disappeared from 1302 Central Italy already at the beginning of the Pleistocene. Engelhardia lasted in Site 380 until the Middle 1303 Pleistocene, but was not found in any Greek record during the Pleistocene.

1304 Similarly, the regional distribution of tree taxa that went extinct in Southern Europe is very diversified. For 1305 the first time we have highlighted that the persistence of Sciadopitys was much longer in Italy than anywhere 1306 else in Europe (Fig. 6). Eucommia had its last refugium near Tenaghi Philippon (Fig. 7), Cathaya in Southern 1307 France (Fig. 6), Taxodium type along the Anatolian coasts (Fig. 6), Cedrus in Rhodes (Fig. 6), probably 1308 Pterocarya in inner Northern Spain (Fig. 8). The recent advances in phylogeographical studies, showing that 1309 the Southern European peninsulas often host genetically different populations of the same species (e.g., 1310 Magri et al., 2006; Bagnoli et al., 2009, 2016; Liepelt et al., 2009), suggest that the different timings of 
1311 extinction of tree populations may be strongly connected to their genetic characters, enhancing or reducing

1312 their ability to cope with unfavorable climate. This is particularly evident when the behavior of different

1313 populations is regionally very diverse. For example, Engelhardia shows very different behaviours in Northern

1314 Spain and Italy, compared to Anatolia. In the case of Taxodium, the Eastern population recorded at Site 380

1315 and the western population in Italy and Spain, separated by a region (Greece) where Taxodium type was

1316 almost absent, may even indicate the presence of different species/genera.

1317 Figs 6-8 clearly indicate that it is not always possible to detect geographical trends in the extinction of tree

1318 populations and confute the commonplace view that tree populations disappeared first at higher latitudes

1319 and then in the southern regions. For example, Engelhardia, Eucommia, and Cathaya appear to persist longer

1320 in Southern France than in peninsular Italy and Greece. The case of Parrotia is even more unexpected, as its

1321 last occurrence in Europe would date back to MIS 11 in Poland (Bińka et al., 2003). This complexity may reflect

1322 the bioclimatic heterogeneity of southern Europe and its mountain ranges, and also highlights the refugial

1323 role of not only Southern Europe but Eastern Europe and connections to Western Asia.

1324 In many cases, the distribution of tree populations on the way to extinction appears fragmented, as

1325 demonstrated by scattered finds in different coeval records. Interestingly, the last occurrences of taxa that

1326 are still living close to continental Europe (e.g., Zelkova, Liquidambar and Cedrus) are found relatively near

1327 to their modern core distribution ranges. Zelkova, still living in Sicily, Crete and in the Hyracanian region, was

1328 last found in the pollen records from Central Italy, Greece, and Black Sea, respectively. Liquidambar, still living

1329 in Southwestern Turkey, had its last appearances in Rhodes and Site 380. Detecting the last fragmented

1330 populations of Cedrus is very difficult, but again the macrofossil find from Rhodes (Boyd, 2009) documents

1331 with certainty its late presence close to its extant range in the Eastern Mediterranean. However, if the most

1332 recent record of Pterocarya in Northeastern Spain will be confirmed, in a location very far from the present

1333 distribution of Pterocarya in the Hyrcanian region, it is also possible that in some cases disjunct populations

1334 may have persisted completely isolated from their distribution center.

1335 The very difficult question of whether the disappearance of tree populations was gradual or step-wise, in

1336 relation to specific climatic events, is probably far from being solved. In many cases, it appears that the 
1337 contemporary extinction of more than one taxon in an area is due to the fragmentary nature of the fossil

1338 record. For example, in Southern Italy, the lack of data between MIS 13 and MIS 5 inevitably produces the

1339 effect of several taxa disappearing at the end of MIS 13. Thus, the availability of long continuous sequences

1340 is absolutely necessary to disentangle this issue. The long record from Tenaghi Philippon (Fig. 5) and the

1341 composite, but rather complete, record from C Italy (Fig. 3) do not show any specific time interval in which

1342 more than one last occurrence is found. Extirpations appear distributed over time, even though broad

1343 changes in dominant forest taxa affect the abundance of multiple species. These patterns appear to reflect

1344 the individualistic species potential to survive beyond the most favourable climatic intervals, through

1345 physiological plasticity, evolutionary adaptation and availability of microclimatic refugia.

1346 It would seem obvious to relate plant extinctions to the harsh dry and cold climate conditions of the glacial

1347 periods (Tzedakis et al., 2006), but the exact timing of extirpation is very difficult to be assessed (see

1348 discussion above) such that we cannot easily reconstruct the climate conditions at the time of extirpation.

1349 While the largest glaciations, such as MIS 22 and MIS 16, seem to play a role in conditioning the change in

1350 forest composition (Tzedakis et al., 2006; Pieruccini et al., 2016), and probably enhanced a general

1351 impoverishment of the flora, individual extinctions are not directly linked to these. One possible way to solve

1352 the problem is to investigate the extirpation modes during the last glacial-interglacial cycle, a time period for 1353 which numerous detailed and well-dated records are available.

1354 A number of tree taxa can be found that have strongly reduced their distribution range during the last tens 1355 of thousands of years in Southern Europe:

1356 - Zelkova was last recorded in Central Italy during one of the final fluctuations of the pleniglacial 1357 interstadials (MIS 3), suggesting its possible extirpation during the last glacial phase (MIS 2). 1358 However, Zelkova was last recorded in Greece 4-3 ka ago, when climate conditions were possibly not 1359 unfavourable to its survival (Fouache et al., 2005).

1360 - Glyptostrobus (Taxodium type) and Carya may have persisted in northern Anatolia until the Holocene 1361 and disappeared in the last few thousand of years (Biltekin et al., 2015). 
- Chamaerops humilis was last recorded at Santorini (macrofossil evidence, Velitzelos et al., 2014) during the Late Pleistocene, pointing to a recent demise of this taxon, which currently has a highly

\section{5} fragmented pan-Mediterranean distribution.

- Buxus (including B. balearica and B. sempervirens) retreated from the southern regions of the Iberian, Italian and Balkan peninsulas during the late Holocene, at the same time of its exponential increase in temperate Europe, thus challenging the common view that the Mediterranean regions are the exclusive and most important refuge areas for evergreen broadleaved trees. During the last 4500 years, populations located in Minorca, Ibiza, Sardinia, Sicily, Apulia, Basilicata, Croatia, Thessaly, W Greece, and Peloponnese have been completely extirpated (Di Domenico et al., 2012). In other areas in Southern Europe a process of severe reduction is still going on, resulting in the modern highly fragmented distribution area, which is a natural residue of a wider distribution. This reduction is even more striking considering that in these regions Buxus persisted throughout the last glacial period.

- Carpinus betulus was commonly traced in the Iberian Peninsula during the Middle Pleistocene (Desprat et al., 2005, 2007). Fossil evidence for Carpinus is still quite common in the Late Pleistocene (Postigo-Mijarra et al., 2008, 2009, 2010; Carrión (Ed.), 2012), followed by extreme reduction during the Holocene (Postigo-Mijarra et al., 2008). The marine sequence MD95-2042 from the Portuguese margin (Sánchez-Goñi et al. 1999, 2008) records Carpinus during the last interglacial Eemian (MIS 5e), and the Area Longa sequence (Gómez-Orellana et al., 2007) during MIS 5c and MIS 4, as well as Sta. Maria de Oia (Gómez-Orellana et al., 2012) and Abric Romaní (Burjachs et al., 2012) during MIS 3. The presence of Carpinus in Pla de l'Estany-Garrotxa (Burjachs, 1990), despite weak chronological control, is also attributed by the author to the Eemian. In the Cañizar de Villarquemado sequence (González-Sampériz et al., 2013; García-Prieto, 2015), Carpinus is recorded in the lower part of the sequence, attributed to MIS 5 (García-Prieto, 2015). During the Holocene, Carpinus populations revealed a progressive depletion, leading to its near disappearance at the Iberian scale: it is sporadically found in records confined to the Cantabrian Mountains (e.g., Lagoa de Lucenza, MuñozSobrino et al., 2001; Chan do Lamoso, Ramil-Rego et al., 1998; La Roya, Allen et al., 1996; Bidasoa, 

Lake: González-Sampériz et al., in press), along the Iberian Range (e.g., Las Pardillas, Sánchez-Goñi and Hannon; Moncayo Massif, Aranbarri et al., 2016), as well as in the Central System (Abel-Schaad et al., 2014). In the Mediterranean realm, sequences from the Balearic Islands (e.g., Cala Galdana and Cala'n Porter, Yll et al., 1997), together with those located from the continental environments (e.g., Espinosa del Cerrato, Franco-Mugica et al., 2001), reveal the latest presences of Carpinus from inland Iberia between 7 and 4 ka BP. The increased vulnerability of Carpinus communities through glacial-interglacial cycles, together with ecological factors (e.g. competition), may have caused the demise of this taxon, whose extirpation from the Iberian Peninsula (excepting a small area in the western Pyrenees, Aizpuru and Catalán, 1984) is still poorly understood.

- Picea, widespread in Southern Europe during the Early Pleistocene (Figs 2-5), underwent a marked 1399 reduction in most southern regions. In the western Balkans at Lake Ohrid, Picea is recorded in low, discontinuous abundances during the last glacial, and generally absent in the Holocene (Sadori et al., 2016). Picea is scarcely recorded in Greece from the Middle Pleistocene onwards, being absent in the Middle Pleistocene diagrams of loannina, Kopais and Megalopolis Basin (Tzedakis, 1994, 1999; Okuda et al., 2001, 2002), and similarly not recorded in the late Upper Pleistocene and Holocene diagrams of Ioannina (Lawson et al., 2004), Nisi Fen (Lawson et al., 2005) or Northern Aegean marine core GeoTü SL152 (Kotthoff et al., 2008). In Southern Italy, the last significant expansion of Picea (>5\%) is found at the onset of the Middle Pleistocene (Capraro et al., 2005), but frequent occurrences of single grains are recorded until the Last Glacial Maximum (Allen et al., 2000). In Central Italy, Picea was abundant in several periods throughout the Pleistocene, its last important expansion (>20\%) being recorded at Boiano (administratively in Southern Italy) during MIS 9 (Orain et al., 2015). Then it decreased and was last found during the Last Glacial Maximum (Follieri et al., 1998). In Northern Italy, Picea is widespread in the Alps, but its populations located in the northern Apennines were strongly reduced during the postglacial waming and were not able to compete with more vigorous tree species (Ravazzi et al., 2006; Magri et al., 2015). In France, the pollen records from the Massif central (Reille et al., 2000) show abundant presence of Picea during all interglacial phases, except the 
1415

1416

1417

1418

1422

1424

Holocene, when it failed to expand after the glacial period. In Spain, Picea is recorded both in the Area Longa pollen spectra during MIS 4 (Gómez-Orellana et al., 2007), and in charcoal remains from La Pila, Santa Catalina and Peña del Perro archaeological sites until the early Holocene (Uzquiano, 1995). On the whole, these data indicate that a declining trend, started in the southern regions of Southern Europe during the Middle Pleistocene, was intensified during the last glacial period and especially at the onset of the Holocene, a phase of global warming, which the most southern populations of Picea in Europe were not able to withstand.

These documented cases of extirpations that occurred during the Holocene prevent ascribing plant extinctions directly to the adverse climate conditions of the glacial periods, although it cannot be excluded that in some cases a legacy of glacial bottlenecks and range contractions may ultimately lead to eventual extirpations during interglacial periods, with a considerable delay (Tzedakis et al., 2006). On the other hand, these examples of recent contraction of distribution ranges need to be interpreted in the light of long-term population dynamics ( $10^{5}-10^{6}$ years), as recognized from fossil data. This may be important to evaluate correctly the vulnerability of modern fragmented plant populations, especially in view of conservation actions, and to reach a better understanding of the causes and mechanisms that drive the reduction of tree populations and their eventual extirpation or even extinction.

\section{Conclusions}

This review on the extinction of tree populations in Southern Europe, based on the collection, organization and interpretation of a large number of pollen and macrofossil records over the Iberian Peninsula, Southern France, the Italian Peninsula, Greece and the Aegean, and the southwestern Black Sea area, has raised a number of methodological issues and highlighted an overall complexity in the timing and modes of plant extinctions.

From the methodological point of view, although fossil records have many inherent uncertainties that are accentuated going back in time to the Middle and Early Pleistocene (e.g., fragmentation, weak chronological setting, reworking and long-distance transport of pollen, lack of modern analogues, taxonomic uncertainties, 
1441 bad preservation state, impossibility to determine the exact timing of extirpation), the overall history of tree

1442 populations is strikingly consistent. This demonstrates that in spite all uncertainties, pollen records provide 1443 excellent information even on fragmentary populations on the way to extinction.

1444 Concerning Pleistocene pollen records from the Mediterranean, two main shortcomings have emerged that 1445 may need to be taken in charge by the scientific community. The first one is the habit of publishing pollen 1446 diagrams including only selected taxa, thus omitting important information on rare occurrences of plant 1447 populations undergoing extinction. A key message to the community is the vital importance of archiving full 1448 pollen data in public repositories, especially in this era of generally concise publication of only summary or 1449 partial pollen datasets. The second one is the need for better photographic atlases and pollen descriptions 1450 that may help palynologists recognizing pollen types of plants that are extinct or living far away. This would 1451 help to align pollen identification by different palynologists.

1452 In many cases, the Quaternary distribution of taxa currently absent from the European mainland, 1453 reconstructed through a detailed analysis of the published data, showed unexpected patterns, indicating that 1454 although their extinction in Europe during the Quaternary was common knowledge, the timing and 1455 geographical trends of their disappearance was far from fully known. The main novel aspects highlighted by 1456 this review are the following:

1457 - Taxodium/Glyptostrobus probably had at least two distinct populations/species/genera in Southern 1458 Europe, which had different fates. One population disappeared from Northern Spain-Southern France 1459 and Central Italy at the end of the Gelasian, persisted in Northern and Southern Italy until the mid1460 Calabrian, and disappeared definitely from Central and Southern Italy after ca. $500 \mathrm{ka}$. The second one 1461 was distributed in Anatolia-Rhodes; it underwent a first severe reduction around 1.2 Ma, and a second 1462 reduction around $500 \mathrm{ka}$, but was able to survive until the Holocene.

1463 - Sciadopitys had a long-term Quaternary refuge in the Italian Peninsula, where it persisted for over one 1464 million years after it had disappeared from the rest of Europe.

1465 - Cathaya, present at all sites during the Gelasian, during the Calabrian was more common in Southern 1466 Italy than in other regions. However, its last occurrence in Italy dates to ca. $850 \mathrm{ka}$, while small relict 
populations may have persisted in isolated locations in France and Anatolia until $700 \mathrm{ka}$ and $380 \mathrm{ka}$, 1468 respectively.

1469 - Cedrus was widespread in Italy and in the Aegean region during the Early Pleistocene. The interpretation 1470 of discontinuous single pollen grains in the Iberian Peninsula and Southern France during the Early 1471 Pleistocene, and in Southern-Central Italy during the Middle Pleistocene, is very uncertain. The age of 1472 the disappearance of Cedrus from southern Europe necessarily requires the support of new macrofossil 1473 data.

1474 - Tsuga has a rather homogenous history in different regions of Southern Europe, with sparse presence in 1475 the most southern sites (Alboran Sea, Rhodes), and significant abundances in Northeastern Spain1476 Southern France and the Italian Peninsula during the Early Pleistocene, especially during the Calabrian. 1477 Its rapid and definitive disappearance is recorded around 750 ka in Northern Italy, around 500 ka in 1478 Southern France and Central Southern Italy, and 280 ka in Anatolia.

1479 - Eucommia persisted in central Europe at least as long as in Southern France, until the late Calabrian. It 1480 expanded in Northern Italy during the Early Pleistocene, without reaching Central Italy, where it was $1481 \quad$ never found.

1482 - Parrotia is not found in Southern Europe after ca. $800 \mathrm{ka}$, which is surprising considering its continuous 1483 record during the Holsteinian in Eastern Poland. This result may suggest different hypotheses on its 1484 persistence areas and Mid-Pleistocene migration routes into Eastern Central Europe.

1485 - Liquidambar, showing scattered populations in various regions of Southern Europe until the end of the 1486 Early Pleistocene, survived longer in Southern France, Southern Italy, and the coasts of the Black Sea, 1487 before being reduced to the small polulations currently living in Rhodes and Southeastern Turkey.

1488 - Engelhardia persisted longer in Northeastern Spain/Southern France (until ca. $1 \mathrm{Ma}$ ) than in the Italian 1489 Peninsula, where it was probably split into two separate populations: one in Southern Italy, persisting 1490 until approx. 1.35 Ma, and one in Northern Italy, lasting until the early Calabrian, separated by a large 1491 region in Central Italy where Engelhardia was absent. A separate population, lasting until ca. $200 \mathrm{ka}$, was 1492 located in the Black Sea region. 
- Carya populations were very vigorous in Italy and France before their decline in the Middle Pleistocene,

1494 and did not show any sign preluding to the impending extirpation. The studies carried out in the last few 1495 years have considerably delayed the age of the last occurrence of Carya, both in the Italian Peninsula 1496 (MIS 9) and in Anatolia (Holocene).

1497 - Pterocarya was more or less present at all European sites with different densities, depending on local 1498 situations, until ca. $400 \mathrm{ka}$, after which time its distribution was severely fragmented. The disappearance 1499 of Pterocarya occurred at different times in different regions. Its last recorded occurrence was possibly 1500 during the Eemian (ca. $120 \mathrm{ka}$ ) in Spain.

1501 - Zelkova pollen was not always distinguished from Ulmus. Even so, the fossil records from Southern 1502 Europe, together with the biogeographical and genetic data available for the extant species, provide a 1503 fairly accurate reconstruction of the history of Zelkova in Southern Europe, except for the Iberian 1504 Peninsula, where either Zelkova disappeared very early compared to the other European regions, or the 1505 scanty fossil record available for the Middle Pleistocene has failed to trace its presence.

1506 In addition to these "classical" extinct trees in Europe, a number of taxa have been considered that are still 1507 widespread in Europe, but have undergone fragmentation/reduction/extirpation in wide areas of Southern 1508 Europe during the late Pleistocene-Holocene. They may provide useful insights into the patterns and timing 1509 of range contraction of plant populations, given the good chronological control of their last occurrences and 1510 the large number of pollen records involved. Three such cases appear of particular interest:

1511 - Buxus retreated from the southern regions of the Iberian, Italian and Balkan peninsulas during the last $15124.5 \mathrm{ka}$, following a general aridification of climate in the Mediterranean Basin. Considering the very low 1513 dispersal ability and growth rate of Buxus, and the current extent of human impact, there is very little 1514 chance that the southern territories of Europe will be naturally recolonized in the future, so the southern 1515 extirpation of Buxus can be considered permanent.

1516 - Carpinus betulus, commonly traced in the Iberian Peninsula during the Middle Pleistocene, was still quite 1517 common in the Late Pleistocene. During the Holocene, Carpinus populations revealed a progressive 1518 depletion in its southwestern range, leading to its virtual absence at the Iberian scale, excepting a small 1519 area in the western Pyrenean valleys. 
- Picea, widespread in Southern Europe during the Early Pleistocene, underwent a marked reduction leading to its disappearance in the most southern regions: in Greece, it was absent in many sites since the Late Pleistocene, in Central-Southern Italy it disappeared during the last glacial maximum, in Northern Spain it was last found in the lateglacial period.

These recent extirpation processes are quite unexpected for three main reasons. Firstly, species like Buxus sempervirens, Carpinus betulus, and Picea abies are not at all considered at risk in Europe. Secondly, they contradict the common view that plant populations persist longer in the southern regions of Europe and, together with indications of complex spatial patterns, rule out a simple North to South trend in extirpations. Thirdly, they occurred at the onset or during the current interglacial, while extinctions are generally considered to be enhanced by the adverse climate conditions of the glacial. This might suggest human impact as a possible cause for the reduction of these taxa. On the other hand, extirpations appear distributed over time during the Quaternary, while it is apparent that significant turnovers of the dominant species have occurred in relation to important climatic/geological transitions, such as at the Gelasian-Calabrian transition, and the so-called Middle Pleistocene Revolution.

Future studies are expected to better define the timing and trends of plant extirpation through the study of new long continuous records, especially from regions that are scarcely known (e.g., the northern Balkan Peninsula and inner Iberia), the re-analyis of some "classical" data with the aim to improve/provide robust chronologies for some undated deposits, so providing better chronological constraints on extinctions, and the publication of all the available data in public repositories. Dealing with extirpations, the most challenging field of research to be explored is certainly the combination of palaeobotanical and genetic studies in relation to the demographic histories of taxa, aimed to assess not only the timing and modes of species/population differentiation, but also the mechanisms of plant extinction.

\section{Acknowledgments}

This paper was in part supported by the projects CGL2012-33063 and CGL2015-69160-R, provided by the Spanish Inter-Ministry Commission of Science and Technology (CICYT). 


\section{References}

Abbazzi, L., Fanfani, F., Ferretti, M.P., Rook, L., Cattani, L., Masini, F., Mallegni, F., Negrino, F., Tozzi, C., 2000. New human remains of archaic Homo sapiens and Lower Palaeolithic industries from Visogliano (Duino Aurisina, Trieste, Italy). Journal of Archaeological Science 27, 11731186. doi:10.1006/jasc.1999.0541

Abel-Schaad, D., Pulido, F., López Sáez, J.A., Alba Sánchez, F., Nieto Lugilde, D., Franco Múgica, F., Pérez Díaz, S., Ruiz Zapata, M.B., Gil García, M.J., Dorado Valiño, M., 2014. Persistence of tree relicts in the Spanish Central System through the Holocene. Lazaroa 35. doi:10.5209/rev_LAZA.2014.v35.41932

Ablin, D., 1991. Analyse pollinique des dépôts lacustres de Ceyssac, Plio-Pléistocène du Velay (Massif central, France). Cahiers de micropaléontologie 6, 21-38.

Aizpuru, I., Catalán P., 1984. The presence of the bombean in the Iberian Península. Anales Jard. Bot. Madrid 41(I),143-146.

Akhani, H., Djamali, M., Ghorbanalizadeh, A., Ramezani, E., 2010. Plant biodiversity of Hyrcanian relict forests, $\mathrm{N}$ Iran: an overview of the flora, vegetation, palaeoecology and conservation. Pakistan Journal of Botany 42, 231-258.

Akhani, H., Salimian, M., 2003. An extant disjunct stand of Pterocarya fraxinifolia (Juglandaceae) in the central Zagros Mountains, W Iran. Willdenowia 33, 113-120. doi:10.3372/wi.33.33111

Allen, J.R., Huntley, B., Watts, W.A., 1996. The vegetation and climate of northwest Iberia over the last 14,000 years. Journal of Quaternary Science 11, 125-147.

Allen, J.R., Watts, W.A., Huntley, B., 2000. Weichselian palynostratigraphy, palaeovegetation and palaeoenvironment; the record from Lago Grande di Monticchio, southern Italy. Quaternary International 73, 91-110.

Allen, J.R.M., Huntley, B., 2009. Last Interglacial palaeovegetation, palaeoenvironments and chronology: a new record from Lago Grande di Monticchio, southern Italy. Quaternary Science Reviews 28, 1521-1538. doi:10.1016/j.quascirev.2009.02.013

Amorosi, A., Colalongo, M.., Fiorini, F., Fusco, F., Pasini, G., Vaiani, S.., Sarti, G., 2004. Palaeogeographic and palaeoclimatic evolution of the Po Plain from 150-ky core records. Global and Planetary Change 40, 55-78. doi:10.1016/S0921-8181(03)00098-5

Antunes, M.T., Mein, P., Nascimento, A., Pais, J., 1986. Le gisement pleistocène de Morgadinho, en Algarve. Ciências da Terra 8, 9-22.

Aranbarri, J., Bartolomé, M., Alcolea, M., Sancho, C., Celant, A., González-Sampériz, P., Arenas, C., Magri, D., Rodríguez-Lázaro, J., 2016. Palaeobotanical insights from Early-Mid Holocene fluvial tufas in the Moncayo Natural Park (Iberian Range, NE Spain): Regional correlations and biogeographic implications. Review of Palaeobotany and Palynology 234, 31-43.

Aranbarri, J., González-Sampériz, P., Valero-Garcés, B., Moreno, A., Gil-Romera, G., Sevilla-Callejo, M., García-Prieto, E., Di Rita, F., Mata, M.P., Morellón, M., Magri, D., Rodríguez-Lázaro, J., Carrión, J.S., 2014. Rapid climatic changes and resilient vegetation during the Lateglacial and Holocene in a continental region of south-western Europe. Global and Planetary Change 114, 50-65. doi:10.1016/j.gloplacha.2014.01.003

Argant, J., 2004. Le gisement pliocène final de Saint-Vallier (Drôme, France): palynologie. Geobios 37, S81-590. 
Arias, C., Bigazzi, G., Bonadonna, F., laccarino, S., Urban, B., Dal Molin, M., Dal Monte, L., Martolini, M., 1990. Valle Ricca Late Neogene stratigraphy (Lazio region, Central Italy). Paléobiologie continentale 17, 61-80.

Bagnoli, F., Tsuda, Y., Fineschi, S., Bruschi, P., Magri, D., Zhelev, P., Paule, L., Simeone, M.C., González-Martínez, S.C., Vendramin, G.G., 2016. Combining molecular and fossil data to infer demographic history of Quercus cerris: insights on European eastern glacial refugia. J. Biogeogr. 43, 679-690. doi:10.1111/jbi.12673

Bagnoli, F., Vendramin, G.G., Buonamici, A., Doulis, A.G., González-Martínez, S.C., La Porta, N., Magri, D., Raddi, P., Sebastiani, F., Fineschi, S., 2009. Is Cupressus sempervirens native in Italy? An answer from genetic and palaeobotanical data. Molecular Ecology 18, 2276-2286. doi:10.1111/j.1365-294X.2009.04182.x

Bell, B.A., Fletcher, W.J., 2016. Modern surface pollen assemblages from the Middle and High Atlas, Morocco: insights into pollen representation and transport. Grana 1-16.

Bellucci, L., Bona, F., Corrado, P., Magri, D., Mazzini, I., Parenti, F., Scardia, G., Sardella, R., 2014. Evidence of late Gelasian dispersal of African fauna at Coste San Giacomo (Anagni Basin, central Italy): Early Pleistocene environments and the background of early human occupation in Europe. Quaternary Science Reviews 96, 72-85. doi:10.1016/j.quascirev.2013.10.011

Ber, A., 2005. Polish Pleistocene stratigraphy-A review of interglacial stratotypes. Netherlands Journal of Geosciences-Geologie en Mijnbouw 84, 61-76.

Bertini, A., 2010. Pliocene to Pleistocene palynoflora and vegetation in Italy: State of the art. Quaternary International 225, 5-24. doi:10.1016/j.quaint.2010.04.025

Bertini, A., 2001. Pliocene climatic cycles and altitudinal forest development from $2.7 \mathrm{Ma}$ in the northern Apennines (Italy): evidence from the pollen record of the Stirone section $(\sim 5.1$ to $2.2 \mathrm{Ma}$ ). Geobios 34, 253-265.

Bertini, A., 2000. Pollen record from Colle Curti and Cesi: Early and Middle Pleistocene mammal sites in the Umbro-Marchean Apennine mountains (central Italy). Journal of Quaternary Science $15,825-840$.

Bertini, A., Magi, M., Mazza, P.P.A., Fauquette, S., 2010. Impact of short-term climatic events on latest Pliocene land settings and communities in Central Italy (Upper Valdarno basin). Quaternary International 225, 92-105. doi:10.1016/j.quaint.2009.05.011

Bertini, A., Martinetto, E., 2011. Reconstruction of vegetation transects for the MessinianPiacenzian of Italy by means of comparative analysis of pollen, leaf and carpological records. Palaeogeography, Palaeoclimatology, Palaeoecology 304, 230-246.

Bertini, A., Roiron, P., 1997. Evolution de la végétation et du climat pendant le Pliocène moyen, en Italie centrale: apport de la palynologie et de la macroflore à l'étude du bassin du Valdarno supérieur (coupe de Santa Barbara). Comptes rendus de l'Académie des sciences. Série 2. Sciences de la terre et des planètes 324, 763-771.

Bertini, A., Toti, F., Marino, M., Ciaranfi, N., 2015. Vegetation and climate across the Early-Middle Pleistocene transition at Montalbano Jonico, southern Italy. Quaternary International 383, 74-88. doi:10.1016/j.quaint.2015.01.003 
1631

1632

1633

1634

1635

1636

1637

1638

1639

1640

1641

1642

1643

1644

1645

1646

1647

1648

1649

1650

1651

1652

1653

1654

1655

1656

1657

1658

1659

1660

1661

1662

1663

1664

1665

1666

1667

1668

1669

1670

1671

1672

Bertoldi, R., 1988. Una sequenza palinologica di età rusciniana nei sedimenti lacustri basali del bacino di Aulla-Olivola (Val di Magra). Rivista Italiana di Paleontologia e Stratigrafia 94, 105-138.

Bhagwat, S.A., Willis, K.J., 2008. Species persistence in northerly glacial refugia of Europe: a matter of chance or biogeographical traits? Journal of Biogeography 35, 464-482. doi:10.1111/j.1365-2699.2007.01861.x

Biltekin, D., 2010. Vegetation and climate of north Anatolian and north Aegean region since $7 \mathrm{Ma}$ according to pollen analysis. PhD Thesis, Université Claude Bernard-Lyon I; Université Technique d'Istanbul.

Biltekin, D., Popescu, S.-M., Suc, J.-P., Quézel, P., Jiménez-Moreno, G., Yavuz, N., Çağatay, M.N., 2015. Anatolia: A long-time plant refuge area documented by pollen records over the last 23million years. Review of Palaeobotany and Palynology 215, 1-22. doi:10.1016/j.revpalbo.2014.12.004

Bińka, K., Nitychoruk, J., Dzierżek, J., 2003. Parrotia persica C.A.M. (Persian witch hazel, Persian ironwood) in the Mazovian (Holsteinian) Interglacial of Poland. Grana 42, 227-233. doi:10.1080/00173130310016220

Birks, H.H., Birks, H.J.B., 2000. Future uses of pollen analysis must include plant macrofossils. Journal of biogeography $27,31-35$.

Bottema, S., 1974. Late Quaternary vegetation history of northwestern Greece. Ph.D. Thesis, University of Groningen.

Bou Dagher-Kharrat, M., Mariette, S., Lefèvre, F., Fady, B., Grenier-de March, G., Plomion, C., Savouré, A., 2007. Geographical diversity and genetic relationships among Cedrus species estimated by AFLP. Tree Genetics \& Genomes 3, 275-285. doi:10.1007/s11295-006-0065$\mathrm{x}$

Boyd, A., 2009. Relict conifers from the mid-Pleistocene of Rhodes, Greece. Historical Biology 21, 115. doi:10.1080/08912960903033301

Brenac, P., 1984. Végétation et climat de la Campanie du Sud (Italie) au Pliocène final d'après l'analyse pollinique des dépôts de Camerota. Ecologia mediterranea 10, 207-216.

Brugal, J.-P., Ambert, P., Bandet, Y., Leroy, S., Roiron, P., Suc, J.-P., Vernet, J.-L., 1990. Mammifères et végétaux du maar Pliocène final de Nogaret (Escandorgue: Hérault, France). Geobios 23 , 231-247.

Burjachs, F., 1990. Palinologia dels dòlmens de l'Alt Empordà i dels dipòsits quaternaris de la cova de l'Arbreda (Serinyà, Pla de l'Estany) i del Pla de l'Estany (Olot, Garrotxa). Evolució del paisatge vegetal i del clima des de fa més de 140.000 anys al NE de la Península Ibèrica. Ph.D. Thesis, Universitat Autònoma de Barcelona, Bellaterra, 324 pp.

Burjachs, F., Julià, R., 1994. Abrupt climatic changes during the last glaciation based on pollen analysis of the Abric Romani, Catalonia, Spain. Quaternary Research 42, 308-315.

Burjachs, F., López-García, J.M., Allué, E., Blain, H.-A., Rivals, F., Bennàsar, M., Expósito, I., 2012. Palaeoecology of Neanderthals during Dansgaard-Oeschger cycles in northeastern Iberia (Abric Romaní): from regional to global scale. Quaternary International 247, 26-37.

Capraro, L., Asioli, A., Backman, J., Bertoldi, R., Channell, J.E.T., Massari, F., Rio, D., 2005. Climatic patterns revealed by pollen and oxygen isotope records across the Matuyama-Brunhes 
Boundary in the central Mediterranean (southern Italy). Geological Society, London, Special Publications 247, 159-182.

Caratini, C., M., Sivak, J., 1972. Pollen de Cathaya (Abietaceae) au tertiaire en France. Pollen et spores $14,169-172$.

Carrión, J., Finlayson, C., Fernandez, S., Finlayson, G., Allue, E., López-Sáez, J.A., López-García, P., GilRomera, G., Bailey, G., González-Sampériz, P., 2008. A coastal reservoir of biodiversity for Upper Pleistocene human populations: palaeoecological investigations in Gorham's Cave (Gibraltar) in the context of the Iberian Peninsula. Quaternary Science Reviews 27, 21182135. doi:10.1016/j.quascirev.2008.08.016

Carrión, J.S., editor, 2012. Paleoflora y Paleovegetación de la Península Ibérica e Islas Baleares: Plioceno-Cuaternario, 1st edition. ed. Murcia.

Carrión, J.S., Fernández, S., González-Sampériz, P., Gil-Romera, G., Badal, E., Carrión-Marco, Y., López-Merino, L., López-Sáez, J.A., Fierro, E., Burjachs, F., 2010. Expected trends and surprises in the Lateglacial and Holocene vegetation history of the Iberian Peninsula and Balearic Islands. Review of Palaeobotany and Palynology 162, 458-475. doi:10.1016/j.revpalbo.2009.12.007

Carrión, J.S., Fuentes, N., González-Sampériz, P., Sánchez Quirante, L., Finlayson, J.C., Fernández, S., Andrade, A., 2007. Holocene environmental change in a montane region of southern Europe with a long history of human settlement. Quaternary Science Reviews 26, 14551475. doi:10.1016/j.quascirev.2007.03.013

Carrión, J.S., Leroy, S.A., 2010. Iberian floras through time: Land of diversity and survival. Review of Palaeobotany and Palynology 162, 227-230.

Carrión, J.S., Sánchez-Gómez, P., Mota, J.F., Yll, R., Chaín, C., 2003. Holocene vegetation dynamics, fire and grazing in the Sierra de Gádor, southern Spain. The Holocene 13, 839-849. doi:10.1191/0959683603hl662rp

Carrión, J.S., van Geel, B., 1999. Fine-resolution Upper Weichselian and Holocene palynological record from Navarrés (Valencia, Spain) and a discussion about factors of Mediterranean forest succession. Review of Palaeobotany and Palynology 106, 209-236.

Cattani, L., Cremaschi, M., Ferraris, M., Mallegni, F., Masini, F., Scola, V., Tozzi, C., 1991. Les gisements du Pléistocène moyen de Visogliano (Trieste): restes humains, industries, environnement. L'Anthropologie 95, 9-35.

Cavallo, P., Martinetto, E., 2001. Flore carpologiche del Pliocene di Castelletto Cervo (Biella). Bollettino-Museo Regionale di Scienze naturali 18, 277-343.

Cheddadi, R., Fady, B., François, L., Hajar, L., Suc, J.-P., Huang, K., Demarteau, M., Vendramin, G.G., Ortu, E., 2009. Putative glacial refugia of Cedrus atlantica deduced from Quaternary pollen records and modern genetic diversity. Journal of Biogeography 36, 1361-1371. doi:10.1111/j.1365-2699.2008.02063.x

Christe, C., Gregor Kozlowski, Frey, D., Bétrisey, S., Maharramova, E., Garfi, G., Pirintsos, S., Naciri, Y., 2014. Footprints of past intensive diversification and structuring in the genus Zelkova (Ulmaceae) in south-western Eurasia. Journal of Biogeography 41, 1081-1093. doi:10.1111/jbi.12276

Combourieu Nebout, N., Londeix, L., Baudin, F., Turon, J.-L., Von Grafenstein, R., Zahn, R., 1999. Quaternary marine and continental paleoenvironments in the western Mediterranean (Site 
976, Alboran Sea): palynological evidence. Proceedings of the Ocean Drilling Program. Scientific Results, pp. 457-468.

Combourieu-Nebout, N., 1993. Vegetation response to Upper Pliocene glacial/interglacial cyclicity in the Central Mediterranean. Quaternary Research 40, 228-236.

Combourieu-Nebout, N., Bertini, A., Russo-Ermolli, E., Peyron, O., Klotz, S., Montade, V., Fauquette, S., Allen, J., Fusco, F., Goring, S., Huntley, B., Joannin, S., Lebreton, V., Magri, D., Martinetto, E., Orain, R., Sadori, L., 2015. Climate changes in the central Mediterranean and Italian vegetation dynamics since the Pliocene. Review of Palaeobotany and Palynology 218, 127147. doi:10.1016/j.revpalbo.2015.03.001

Combourieu-Nebout, N., Foucault, A., Mélières, F., 2004. Vegetation markers of palaeoclimate cyclical changes in the Pliocene of Punta Piccola (Sicily, Italy). Palaeogeography, Palaeoclimatology, Palaeoecology 214, 55-66. doi:10.1016/j.palaeo.2004.07.021

Combourieu-Nebout, N., Peyron, O., Dormoy, I., Desprat, S., Beaudouin, C., Kotthoff, U., Marret, F., 2009. Rapid climatic variability in the west Mediterranean during the last 25000 years from high resolution pollen data. Climate of the Past 5, 503-521.

Combourieu-Nebout, N., Vergnaud-Grazzini, C., 1991. Late Pliocene northern hemisphere glaciations: the continental and marine responses in the central Mediterranean. Quaternary Science Reviews 10, 319-334.

Corrado, P., Magri, D., 2011. A late Early Pleistocene pollen record from Fontana Ranuccio (central Italy). Journal of Quaternary Science 26, 335-344. doi:10.1002/jqs.1459

Cortés-Sánchez, M., Morales-Muñiz, A., Simón-Vallejo, M.D., Bergadà-Zapata, M.M., DelgadoHuertas, A., López-García, P., López-Sáez, J.A., Lozano-Francisco, M.C., Riquelme-Cantal, J.A., Roselló-Izquierdo, E., others, 2008. Palaeoenvironmental and cultural dynamics of the coast of Málaga (Andalusia, Spain) during the Upper Pleistocene and early Holocene. Quaternary Science Reviews 27, 2176-2193.

Cross, J., Pérez Obiol, R., Roure, J.M., 1986. Primeres dades sobre la vegetació i el clima del Quaternari mitjà a Olot. Collectanea botanica 16, 365-369.

Dawson, T.P., Jackson, S.T., House, J.I., Prentice, I.C., Mace, G.M., 2011. Beyond predictions: biodiversity conservation in a changing climate. science 332, 53-58.

Degeai, J.-P., Pastre, J.-F., Gauthier, A., Robert, V., Nomade, S., Bout-Roumazeilles, V., Guillou, H., 2013. La séquence lacustre du maar d'Alleret (Massif Central, France): téphrochronologie et évolution paléoenvironnementale en Europe occidentale au début du Pléistocène moyen. Quaternaire 443-459. doi:10.4000/quaternaire.6808

Denk, T., Grimm, G.W., 2005. Phylogeny and biogeography of Zelkova (Ulmaceae sensu stricto) as inferred from leaf morphology, ITS sequence data and the fossil record. Botanical Journal of the Linnean Society 147, 129-157. doi:10.1111/j.1095-8339.2005.00354.x

Desprat, S., Sánchez Goni, M.F., McManus, J.F., Duprat, J., Cortijo, E., 2009. Millennial-scale climatic variability between 340000 and 270000 years ago in SW Europe: evidence from a NW Iberian margin pollen sequence. Climate of the Past 5, 53-72.

Desprat, S., Sánchez Goñi, M.F., Naughton, F., Turon, J.-L., Duprat, J., Malaizé, B., Cortijo, E., Peypouquet, J.-P., 2007. Climate variability of the last five isotopic interglacials: Direct landsea-ice correlation from the multiproxy analysis of North-Western Iberian margin deep-sea cores. Developments in Quaternary Sciences 7, 375-386. 
Desprat, S., Sánchez Goñi, M.F., Turon, J.-L., McManus, J.F., Loutre, M.F., Duprat, J., Malaizé, B., Peyron, O., Peypouquet, J.-P., 2005. Is vegetation responsible for glacial inception during periods of muted insolation changes? Quaternary Science Reviews 24, 1361-1374. doi:10.1016/j.quascirev.2005.01.005

Di Domenico, F., Lucchese, F., Magri, D., 2012. Buxus in Europe: Late Quaternary dynamics and modern vulnerability. Perspectives in Plant Ecology, Evolution and Systematics 14, 354362. doi:10.1016/j.ppees.2012.07.001

Di Rita, F., Anzidei, A.P., Magri, D., 2013. A Lateglacial and early Holocene pollen record from Valle di Castiglione (Rome): Vegetation dynamics and climate implications. Quaternary International 288, 73-80. doi:10.1016/j.quaint.2011.11.011

Di Rita, F., Celant, A., Milli, S., Magri, D., 2015. Lateglacial-early Holocene vegetation history of the Tiber delta (Rome, Italy) under the influence of climate change and sea level rise. Review of Palaeobotany and Palynology 218, 204-2016. doi:10.1016/j.revpalbo.2014.12.005

Eiserhardt, W.L., Borchsenius, F., Plum, C.M., Ordonez, A., Svenning, J.-C., 2015. Climate-driven extinctions shape the phylogenetic structure of temperate tree floras. Ecology Letters 18, 263-272. doi:10.1111/ele.12409

Elhaï, H., 1969. La flore sporo-pollinique du gisement Villafranchien de Senèze (Massif-CentralFrance). Pollen et Spores 11, 127-139.

Fady, B., Lefèvre, F., Vendramin, G.G., Ambert, A., Régnier, C., Bariteau, M., 2008. Genetic consequences of past climate and human impact on eastern Mediterranean Cedrus libani forests. Implications for their conservation. Conservation Genetics 9, 85-95. doi:10.1007/s10592-007-9310-6

Falguères, C., Bahain, J.-J., Tozzi, C., Boschian, G., Dolo, J.-M., Mercier, N., Valladas, H., Yokoyama, Y., 2008. ESR/U-series chronology of the Lower Palaeolithic palaeoanthropological site of Visogliano, Trieste, Italy. Quaternary Geochronology 3, 390-398. doi:10.1016/j.quageo.2008.01.007

Fang, J., Wang, Z., Tang, Z., 2011. Atlas of woody plants in China: distribution and climate. Springer Science \& Business Media.

Farjon, A., 2008. A natural history of conifers. Timber Press.

Farjon, A., 2005. A monograph of Cupressaceae and Sciadopitys. Royal Botanic Gardens, Kew:

Fauquette, S., Clauzon, G., Suc, J.-P., Zheng, Z., 1999. A new approach for palaeoaltitude estimates based on pollen records: example of the Mercantour Massif (southeastern France) at the earliest Pliocene. Earth and Planetary Science Letters 170, 35-47.

Feddi, N., Fauquette, S., Suc, J.-P., 2011. Histoire plio-pléistocène des écosystèmes végétaux de Méditerranée sud-occidentale: apport de l'analyse pollinique de deux sondages en mer d'Alboran. Geobios 44, 57-69. doi:10.1016/j.geobios.2010.03.007

Field, M.., de Beaulieu, J.-L., Guiot, J., Ponel, P., 2000. Middle Pleistocene deposits at La Côte, Valde-Lans, Isère department, France: plant macrofossil, palynological and fossil insect investigations. Palaeogeography, Palaeoclimatology, Palaeoecology 159, 53-83. doi:10.1016/S0031-0182(00)00032-8

Filipova-Marinova, M.V., Kvavadze, E.V., Connor, S.E., Sjögren, P., 2010. Estimating absolute pollen productivity for some European Tertiary-relict taxa. Vegetation History and Archaeobotany 19, 351-364. 
1802

1803

1804

1805

1806

1807

1808

1809

1810

1811

1812

1813

1814

1815

1816

1817

1818

1819

1820

1821

1822

1823

1824

1825

1826

1827

1828

1829

1830

1831

1832

1833

1834

1835

1836

1837

1838

1839

1840

1841

1842

1843

1844

Fletcher, W.J., Müller, U.C., Koutsodendris, A., Christanis, K., Pross, J., 2013. A centennial-scale record of vegetation and climate variability from 312 to $240 \mathrm{ka}$ (Marine Isotope Stages 9ca, 8 and 7e) from Tenaghi Philippon, NE Greece. Quaternary Science Reviews 78, 108-125. doi:10.1016/j.quascirev.2013.08.005

Fletcher, W.J., Sánchez Goñi, M.F., 2008. Orbital- and sub-orbital-scale climate impacts on vegetation of the western Mediterranean basin over the last 48,000 yr. Quaternary Research 70, 451-464. doi:10.1016/j.yqres.2008.07.002

Florschütz, F., Amor, J.M., Wijmstra, T., 1971. Palynology of a thick Quaternary succession in southern Spain. Palaeogeography, Palaeoclimatology, Palaeoecology 10, 233-264.

Follieri, M., 2010. Conifer extinction in Quaternary Italian records. Quaternary International 225, 37-43. doi:10.1016/j.quaint.2010.02.001

Follieri, M., 1962. La foresta colchica fossile di Riano Romano. II. Analisi polliniche. Annali di Botanica 27, 245-280.

Follieri, M., 1958. La foresta colchica fossile di Riano Romano. I. Studio dei fossili vegetali macroscopici. Annali di Botanica 26, 129-142.

Follieri, M., Magri, D., Sadori, L., 1989. Pollen stratigraphical synthesis from Valle di Castiglione (Roma). Quaternary International 3, 81-84.

Follieri, M., Magri, D., Sadori, L., 1988. 250000-year pollen record from Valle di Castiglione (Roma). Pollen et Spores 30, 329-356.

Follieri, M., Magri, D., Sadori, L., 1986. Late Pleistocene Zelkova extinction in central Italy. New Phytologist 103, 269-273.

Fouache, É., Dalongeville, R., Kunesch, S., Suc, J., Subally, D., Prieur, A., Lozouet, P., 2005. The environmental setting of the harbor of the classical site of Oeniades on the Acheloos delta, Greece. Geoarchaeology 20, 285-302.

Franco Múgica, F., García Antón, M., Maldonado Ruiz, J., Morla Juaristi, C., Sainz-Ollero, H., 2001. The Holocene history of Pinus forests in the Spanish Northern Meseta. The Holocene 11, 343-358. doi:10.1191/095968301669474913

Fusco, F., 2007. Vegetation response to early Pleistocene climatic cycles in the Lamone valley (Northern Apennines, Italy). Review of Palaeobotany and Palynology 145, 1-23. doi:10.1016/j.revpalbo.2006.08.005

García-Antón, M., Sainz-Ollero, H., 1991. Pollen records from the middle Pleistocene Atapuerca site (Burgos, Spain). Palaeogeography, Palaeoclimatology, Palaeoecology 85, 199-206.

García-Prieto, E., 2015. Dinámica paleoambiental durante los últimos 135.000 años en el Alto Jiloca: el registro lacustre de El Cañizar (PhD Thesis). Universidad de Zaragoza, Spain.

Garfi, G., Carimi, F., Pasta, S., Rühl, J., Trigila, S., 2011. Additional insights on the ecology of the relic tree Zelkova sicula di Pasquale, Garfi et Quézel (Ulmaceae) after the finding of a new population. Flora - Morphology, Distribution, Functional Ecology of Plants 206, 407-417. doi:10.1016/j.flora.2010.11.004

Gavin, D.G., Fitzpatrick, M.C., Gugger, P.F., Heath, K.D., Rodríguez-Sánchez, F., Dobrowski, S.Z., Hampe, A., Hu, F.S., Ashcroft, M.B., Bartlein, P.J., Blois, J.L., Carstens, B.C., Davis, E.B., de Lafontaine, G., Edwards, M.E., Fernandez, M., Henne, P.D., Herring, E.M., Holden, Z.A., Kong, W., Liu, J., Magri, D., Matzke, N.J., McGlone, M.S., Saltré, F., Stigall, A.L., Tsai, Y.-H.E., Williams, J.W., 2014. Climate refugia: joint inference from fossil records, species 
distribution models and phylogeography. New Phytologist 204, 37-54. doi:10.1111/nph.12929

Geurts, M., 1979. Approche palynostratigraphique des depots calcareux quaternaires dans la region de Banyoles-Besalc (Catalogne), in: Actas de La IV Reunión Del Grupo de Trabajo Del Cuaternario. pp. 106-115.

Geurts, M., 1977. Premières données a l'étude paplynologique des dépôts calcareux quaternaires en Catalogne. Acta geológica hispánica 12, 86-89.

Gibbard, P.L., Head, M.J., Walker, M.J.C., the Subcommission on Quaternary Stratigraphy, 2010. Formal ratification of the Quaternary System/Period and the Pleistocene Series/Epoch with a base at 2.58 Ma. Journal of Quaternary Science 25, 96-102. doi:10.1002/jqs.1338

Gómez-Orellana, L., Ramil-Rego, P., Muñoz Sobrino, C., 2013. The response of vegetation at the end of the last glacial period (MIS 3 and MIS 2) in littoral areas of NW Iberia. Boreas 42, 729744.

Gómez-Orellana, L., Ramil-Rego, P., Muñoz Sobrino, C., 2007. The Würm in NW Iberia, a pollen record from Area Longa (Galicia). Quaternary Research 67, 438-452. doi:10.1016/j.yqres.2007.01.003

González-Sampériz, P., Aranbarri, J., Pérez-Sanz, A., Gil-Romera, G., Moreno, A., Leunda, M., SevillaCallejo, M., Corella, J.P., Morellón, M., Oliva, B., Valero-Garcés, 2016. Environmental and climate change in the southern Central Pyrenees since the Last Glacial Maximum: A view from the lake records. Catena.

González-Sampériz, P., García-Prieto, E., Aranbarri, J., Valero Garcés, B.L., Moreno, A., G. GilRomera, Sevilla Callejo, M., Santos, L., Morellón, M., Mata, P., Andrade, A., Carrión, J., 2013. Reconstrucción paleoambiental del último ciclo glacial-interglacial en la Iberia continental: la secuencia del Cañizar de Villarquemado (Teruel). Cuadernos de investigación geográfica 49-76.

González-Sampériz, P., Leroy, S.A.G., Carrión, J.S., Fernández, S., García-Antón, M., Gil-García, M.J., Uzquiano, P., Valero-Garcés, B., Figueiral, I., 2010. Steppes, savannahs, forests and phytodiversity reservoirs during the Pleistocene in the Iberian Peninsula. Review of Palaeobotany and Palynology 162, 427-457. doi:10.1016/j.revpalbo.2010.03.009

Gregor, H.-J., 1986. Preliminary report about the macrofloral history of the Stirone-river sequence (Zanclean, Piacenzian, "Calabrian"). Memorie della Società Geologica Italiana 31, 219-227.

Hably, L., Kvacek, Z., 1998. Pliocene mesophytic forests surrounding crater lakes in western Hungary. Review of Palaeobotany and Palynology 101, 257-269.

Hajar, L., François, L., Khater, C., Jomaa, I., Déqué, M., Cheddadi, R., 2010. Cedrus libani (A. Rich) distribution in Lebanon: Past, present and future. Comptes Rendus Biologies 333, 622-630. doi:10.1016/j.crvi.2010.05.003

Hajar, L., Haïdar-Boustani, M., Khater, C., Cheddadi, R., 2010. Environmental changes in Lebanon during the Holocene: Man vs. climate impacts. Journal of Arid Environments 74, 746-755. doi:10.1016/j.jaridenv.2008.11.002

Hajar, L., Khater, C., Cheddadi, R., 2008. Vegetation changes during the late Pleistocene and Holocene in Lebanon: a pollen record from the Bekaa Valley. The Holocene 18, 1089-1099. doi:10.1177/0959683608095580 
1887

1888

1889

1890

1891

1892

1893

1894

1895

1896

1897

1898

1899

1900

1901

1902

1903

1904

1905

1906

1907

1908

1909

1910

1911

1912

1913

1914

1915

1916

1917

1918

1919

1920

1921

1922

1923

1924

1925

1926

1927

1928

1929

Hammen, T. van der, 1951. A contribution to the palaeobotany of the Tiglian. Geologie Mijnbouw, ns 13, 242-250.

Hammen, T. van der, Wijmstra, T.A., Zagwijn, W., 1971. The floral record of the late Cenozoic of Europe, in: Turekian, K.K. (Ed.). The Late Cenozoic Glacial Ages. Yale University Press, New Haven, pp. 391-424.

Head, M.J., Gibbard, P.L., 2005. Early-Middle Pleistocene transitions: an overview and recommendation for the defining boundary. Geological Society, London, Special Publications 247, 1-18.

Hooghiemstra, H., Lézine, A.-M., Leroy, S.A.G., Dupont, L., Marret, F., 2006. Late Quaternary palynology in marine sediments: A synthesis of the understanding of pollen distribution patterns in the NW African setting. Quaternary International 148, 29-44. doi:10.1016/j.quaint.2005.11.005

Huntley, B., 1993. Species-richness in north-temperate zone forests. Journal of Biogeography 20, 163-180.

Iriarte-Chiapusso, M., Muñoz Sobrino, C., Gómez-Orellana, L., Hernández-Beloqui, B., GarcíaMoreiras, I., Fernández Rodriguez, C., Heiri, O., Lotter, A., Ramil-Rego, P., 2016. Reviewing the Lateglacial-Holocene transition in NW Iberia: A palaeoecological approach based on the comparison between dissimilar regions. Quaternary International 403, 211-236.

Ivanov, D., Ashraf, A.R., Mosbrugger, V., Palamarev, E., 2002. Palynological evidence for Miocene climate change in the Forecarpathian Basin (Central Paratethys, NW Bulgaria). Palaeogeography, Palaeoclimatology, Palaeoecology 178, 19-37. doi:10.1016/S00310182(01)00365-0

Jackson, S.T., Weng, C., 1999. Late Quaternary extinction of a tree species in eastern North America. Proceedings of the National Academy of Sciences 96, 13847-13852.

Janssen, C., 1984. Modern pollen assemblages and vegetation in the Myrtle Lake peatland, Minnesota. Ecological Monographs 54, 213-252.

Jasińska, A.K., Boratyńska, K., Sobierajska, K., Romo, A., Ok, T., Kharat, M.B.D., Boratyński, A., 2013. Relationships among Cedrus libani, C. brevifolia and C. atlantica as revealed by the morphological and anatomical needle characters. Plant Systematics and Evolution 299, 3548. doi:10.1007/s00606-012-0700-y

Jiménez-Moreno, G., Fauquette, S., Suc, J., 2008. Vegetation, climate and palaeoaltitude reconstructions of the Eastern Alps during the Miocene based on pollen records from Austria, Central Europe. Journal of Biogeography 35, 1638-1649.

Jiménez-Moreno, G., Fauquette, S., Suc, J.-P., 2010. Miocene to Pliocene vegetation reconstruction and climate estimates in the Iberian Peninsula from pollen data. Review of Palaeobotany and Palynology 162, 403-415. doi:10.1016/j.revpalbo.2009.08.001

Jiménez-Moreno, G., Suc, J.-P., 2007. Middle Miocene latitudinal climatic gradient in Western Europe: Evidence from pollen records. Palaeogeography, Palaeoclimatology, Palaeoecology 253, 208-225. doi:10.1016/j.palaeo.2007.03.040

Joannin, S., 2007. Changements climatiques en méditerranée à la transition Pléistocène inférieurmoyen: pollens, isotopes stables et cyclostratigraphie. Université Claude Bernard-Lyon I.

Joannin, S., Bassinot, F., Nebout, N.C., Peyron, O., Beaudouin, C., 2011. Vegetation response to obliquity and precession forcing during the Mid-Pleistocene Transition in Western 
Mediterranean region (ODP site 976). Quaternary Science Reviews 30, 280-297. doi:10.1016/j.quascirev.2010.11.009

Joannin, S., Ciaranfi, N., Stefanelli, S., 2008. Vegetation changes during the late Early Pleistocene at Montalbano Jonico (Province of Matera, southern Italy) based on pollen analysis. Palaeogeography, Palaeoclimatology, Palaeoecology 270, 92-101. doi:10.1016/j.palaeo.2008.08.017

Joannin, S., Cornée, J.-J., Moissette, P., Suc, J.-P., Koskeridou, E., Lécuyer, C., Buisine, C., Kouli, K., Ferry, S., 2007a. Changes in vegetation and marine environments in the eastern Mediterranean (Rhodes, Greece) during the Early and Middle Pleistocene. Journal of the Geological Society 164, 1119-1131.

Joannin, S., Quillévéré, F., Suc, J.-P., Lécuyer, C., Martineau, F., 2007b. Early Pleistocene climate changes in the central Mediterranean region as inferred from integrated pollen and planktonic foraminiferal stable isotope analyses. Quaternary Research 67, 264-274. doi:10.1016/j.yqres.2006.11.001

Julia Bruguès, R., Suc, J.-P., 1980. Analyse pollinique des dépôts lacustres du Pléistocène inférieur de Banyoles (Bañolas, site de la Bòbila Ordis-Espagne): un élément nouveau dans la reconstitution de l'histoire paléoclimatique des régions méditerranéennes d'Europe occidentale. Geobios 13, 5-19.

Kahlke, R.-D., García, N., Kostopoulos, D.S., Lacombat, F., Lister, A.M., Mazza, P.P., Spassov, N., Titov, V.V., 2011. Western Palaearctic palaeoenvironmental conditions during the Early and early Middle Pleistocene inferred from large mammal communities, and implications for hominin dispersal in Europe. Quaternary Science Reviews 30, 1368-1395.

Kemna, H.A., Westerhoff, W.E., 2007. Remarks on the palynology-based chronostratigraphical subdivision of Pliocene terrestrial deposits in NW-Europe. Quaternary international 164, 184-196.

Klotz, S., Fauquette, S., Combourieu-Nebout, N., Uhl, D., Suc, J.-P., Mosbrugger, V., 2006. Seasonality intensification and long-term winter cooling as a part of the Late Pliocene climate development. Earth and Planetary Science Letters 241, 174-187. doi:10.1016/j.epsl.2005.10.005

Kotthoff, U., Muller, U.C., Pross, J., Schmiedl, G., Lawson, I.T., van de Schootbrugge, B., Schulz, H., 2008. Lateglacial and Holocene vegetation dynamics in the Aegean region: an integrated view based on pollen data from marine and terrestrial archives. The Holocene 18, 10191032. doi:10.1177/0959683608095573

Kovar-Eder, J., Kvaček, Z., Martinetto, E., Roiron, P., 2006. Late Miocene to Early Pliocene vegetation of southern Europe (7-4 Ma) as reflected in the megafossil plant record. Palaeogeography, Palaeoclimatology, Palaeoecology 238, 321-339. doi:10.1016/j.palaeo.2006.03.031

Kozlowski, G., Frey, D., Fazan, L., Egli, B., Bétrisey, S., Gratzfeld, J., Garfi, G., Pirintsos, S., 2014. The Tertiary relict tree Zelkova abelicea (Ulmaceae): distribution, population structure and conservation status on Crete. Oryx 48, 80-87. doi:10.1017/S0030605312001275

Kozlowski, G., Gibbs, D., Huan, F., Frey, D., Gratzfeld, J., 2012. Conservation of threatened relict trees through living ex situ collections: lessons from the global survey of the genus Zelkova (Ulmaceae). Biodiversity and Conservation 21, 671-685.

Kuprianova, L., 1965. The palynology of the Amentiferae. The Academy of Sciences of the USSR, Moscow 214. 
1974

1975

1976

1977

1978

1979

1980

1981

1982

1983

1984

1985

1986

1987

1988

1989

1990

1991

1992

1993

1994

1995

1996

1997

1998

1999

2000

2001

2002

2003

2004

2005

2006

2007

2008

2009

2010

2011

2012

2013

2014

2015

Kvavadze, E.V., Connor, S.E., 2005. Zelkova carpinifolia (Pallas) K. Koch in Holocene sediments of Georgia-an indicator of climatic optima. Review of Palaeobotany and Palynology 133, 6989. doi:10.1016/j.revpalbo.2004.09.002

Lamb, H.F., Eicher, U., Switsur, V.R., 1989. An 18,000-Year Record of Vegetation, Lake-Level and Climatic Change from Tigalmamine, Middle Atlas, Morocco. Journal of Biogeography 16, 65. doi:10.2307/2845311

Lawson, I., Frogley, M., Bryant, C., Preece, R., Tzedakis, P., 2004. The Lateglacial and Holocene environmental history of the Ioannina basin, north-west Greece. Quaternary Science Reviews 23, 1599-1625. doi:10.1016/j.quascirev.2004.02.003

Lawson, I.T., Al-Omari, S., Tzedakis, P.C., Bryant, C.L., Christanis, K., 2005. Lateglacial and Holocene vegetation history at Nisi Fen and the Boras mountains, northern Greece. The Holocene 15, 873-887. doi:10.1191/0959683605hl860ra

Lebreton, V., 2002. Végétation et climat au Pléistocène inférieur et moyen à La Pineta (Isernia, Italie). Comptes Rendus Palevol 1, 11-17.

LePage, B.A., 2003. A new species of Tsuga (Pinaceae) from the middle Eocene of Axel Heiberg Island, Canada, and an assessment of the evolution and biogeographical history of the genus. Botanical Journal of the Linnean Society 141, 257-296. doi:10.1046/j.10958339.2003.00131.x

Leroy, S., Ambert, P., Suc, J.-P., 1994. Pollen record of the Saint-Macaire maar (Hérault, southern France): a Lower Pleistocene glacial phase in the Languedoc coastal plain. Review of Palaeobotany and Palynology 80, 149-157.

Leroy, S.A., Tudryn, A., Chalié, F., López-Merino, L., Gasse, F., 2013. From the Allerød to the midHolocene: palynological evidence from the south basin of the Caspian Sea. Quaternary Science Reviews 78, 77-97.

Leroy, S.A.G., 2008. Vegetation cycles in a disturbed sequence around the Cobb-Mountain subchron in Catalonia (Spain). Journal of Paleolimnology 40, 851-868. doi:10.1007/s10933-0089203-9

Leroy, S.A.G., 2007. Progress in palynology of the Gelasian-Calabrian Stages in Europe: Ten messages. Revue de Micropaléontologie 50, 293-308. doi:10.1016/j.revmic.2006.08.001

Leroy, S.A.G., 1997. Climatic and non-climatic lake-level changes inferred from a Plio-Pleistocene lacustrine complex of Catalonia (Spain): palynology of the Tres Pins sequences. Journal of Paleolimnology 17, 347-367.

Leroy, S.A.G., 1990. Paléoclimats plio-pléistocènes en Catalogne et Languedoc d'après la palynologie de formations lacustres. These de l'Université Catholique de Louvain, Belgique 319.

Leroy, S.A.G., Arpe, K., Mikolajewicz, U., 2011. Vegetation context and climatic limits of the Early Pleistocene hominin dispersal in Europe. Quaternary Science Reviews 30, 1448-1463. doi:10.1016/j.quascirev.2010.01.017

Leroy, S.A.G., Roiron, P., 1996. Latest Pliocene pollen and leaf floras from Bernasso palaeolake (Escandorgue Massif, Hérault, France). Review of Palaeobotany and Palynology 94, 295328.

Leroy, S., Seret, G., 1992. Duration and Vegetation Dynamic of the Nogaret Interglacial (-1.9 Ma, S. of France): Tentative Correlation with Stage 75, in: Start of a Glacial. Springer, pp. 113-125. 
Li, J., Del Tredici, P., 2008. The Chinese Parrotia: a sibling species of the Persian Parrotia. Arnoldia 66, 2-9.

Liepelt, S., Cheddadi, R., de Beaulieu, J.-L., Fady, B., Gömöry, D., Hussendörfer, E., Konnert, M., Litt, T., Longauer, R., Terhürne-Berson, R., Ziegenhagen, B., 2009. Postglacial range expansion and its genetic imprints in Abies alba (Mill.) - A synthesis from palaeobotanic and genetic data. Review of Palaeobotany and Palynology 153, 139-149. doi:10.1016/j.revpalbo.2008.07.007

Liu, Y.-S., Basinger, J.F., 2000. Fossil Cathaya (Pinaceae) pollen from the Canadian high arctic. International Journal of Plant Sciences 161, 829-847.

Lona, F., 1950. Contributi alla storia della vegetazione e del clima nella Val Padana: analisi pollinica del giacimento villafranchiano di Leffe (Bergamo). Atti della Società Italiana di Scienze Naturali 89, 123-178.

Lona, F., Bertoldi, R., 1972. La storia del Plio-Pleistocene italiano in alcune sequenze vegetazionali lacustri e marine. Atti della Accademia Nazionale dei Lincei 11, 1-45.

Lona, F., Ricciardi, E., 1961. Studio pollinologico stratigrafico su una serie lacustre pleistocenica dell'Italia centrale (Bacino di Gubbio, Perugia). Pollen et Spores 3, 93-100.

Løvlie, R., Leroy, S., 1995. Magnetostratigraphy of Lower Pleistocene Banyoles palaeolake carbonate sediments from Catalonia, NE Spain: evidence for relocation of the Cobb Mountain subchron. Quaternary Science Reviews 14, 473-485.

Magri, D., 2012. Quaternary history of Cedrus in Southern Europe. Annali di Botanica 2, 57-66.

Magri, D., 2010. Persistence of tree taxa in Europe and Quaternary climate changes. Quaternary International 219, 145-151. doi:10.1016/j.quaint.2009.10.032

Magri, D., 1999. Late Quaternary vegetation history at Lagaccione near Lago di Bolsena (central Italy). Review of Palaeobotany and Palynology 106, 171-208.

Magri, D., Agrillo, E., Di Rita, F., Furlanetto, G., Pini, R., Ravazzi, C., Spada, F., 2015. Holocene dynamics of tree taxa populations in Italy. Review of Palaeobotany and Palynology 218, 267-284. doi:10.1016/j.revpalbo.2014.08.012

Magri, D., Palombo, M.R., 2013. Early to Middle Pleistocene dynamics of plant and mammal communities in South West Europe. Quaternary International 288, 63-72. doi:10.1016/j.quaint.2012.02.028

Magri, D., Parra, I., 2002. Late Quaternary western Mediterranean pollen records and African winds. Earth and Planetary Science Letters 200, 401-408.

Magri, D., Rita, F.D., Palombo, M.R., 2010. An Early Pleistocene interglacial record from an intermontane basin of central Italy (Scoppito, L'Aquila). Quaternary International 225, 106113. doi:10.1016/j.quaint.2009.04.005

Magri, D., Sadori, L., 1999. Late Pleistocene and Holocene pollen stratigraphy at Lago di Vico, central Italy. Vegetation history and archaeobotany 8, 247-260.

Magri, D., Vendramin, G.G., Comps, B., Dupanloup, I., Geburek, T., Gomory, D., Latalowa, M., Litt, T., Paule, L., Roure, J.M., Tantau, I., van der Knaap, W.O., Petit, R.J., de Beaulieu, J.-L., 2006. A new scenario for the Quaternary history of European beech populations: palaeobotanical evidence and genetic consequences. New Phytologist 171, 199-221. doi:10.1111/j.14698137.2006.01740.x 
Mai, D.H., Velitzelos, E., 2007. The fossil flora of Kallithea (Rhodes, Greece) at the Pliocene/Pleistocene boundary. Palaeontographica Abteilung B 75-99.

Manchester, S.R., 1987. The fossil history of the Juglandaceae. Monographs in Systematic Botany, Missouri bot. Gard 21, 1-137.

Manzi, G., Magri, D., Milli, S., Palombo, M.R., Margari, V., Celiberti, V., Barbieri, M., Barbieri, M., Melis, R.T., Rubini, M., Ruffo, M., Saracino, B., Tzedakis, P.C., Zarattini, A., Biddittu, I., 2010. The new chronology of the Ceprano calvarium (Italy). Journal of Human Evolution 59, 580585. doi:10.1016/j.jhevol.2010.06.010

Marra, F., Sottili, G., Gaeta, M., Giaccio, B., Jicha, B., Masotta, M., Palladino, D.M., Deocampo, D.M., 2014. Major explosive activity in the Monti Sabatini Volcanic District (central Italy) over the 800-390 ka interval: geochronological-geochemical overview and tephrostratigraphic implications. Quaternary Science Reviews 94, 74-101. doi:10.1016/j.quascirev.2014.04.010

Martinetto, E., 2015. Monographing the Pliocene and early Pleistocene carpofloras of Italy: methodological challenges and current progress. Palaeontographica Abteilung B 57-99.

Martinetto, E., 2009. Palaeoenvironmental significance of plant macrofossils from the Piànico Formation, Middle Pleistocene of Lombardy, North Italy. Quaternary International 204, 20 30. doi:10.1016/j.quaint.2008.11.014

Martinetto, E., 2001. The role of central Italy as a centre of refuge for thermophilous plants in the late Cenozoic. Acta Palaeobotanica 41, 299-319.

Martinetto, E., Bertini, A., Basilici, G., Baldanza, A., Bizzarri, R., Cherin, M., Gentili, S., Pontini, M.R., 2014. The plant record of the Dunarobba and Pietrafitta sites in the Plio-Pleistocene palaeoenvironmental context of Central Italy. Alpine and Mediterranean Quaternary 27, 29-72.

Martinetto, E., Monegato, G., Irace, A., Vaiani, S.C., Vassio, E., 2015. Pliocene and Early Pleistocene carpological records of terrestrial plants from the southern border of the Po Plain (northern Italy). Review of Palaeobotany and Palynology 218, 148-166. doi:10.1016/j.revpalbo.2014.10.007

Martinetto, E., Monegato, G., Vassio, E., 2012. An Early Pleistocene plant assemblage with East European affinity in the Venetian-Friulian basin (NE Italy). Alpine and Mediterranean Quaternary 25, 91-104.

Martinetto, E., Sami, M., 2001. Paleoflora delle "sabbie gialle" mediopleistoceniche di Oriolo, presso Faenza (Ravenna). Quaderno di Studi e notizie di storia Naturale della Romagna 14, 1-28.

Massari, F., Rio, D., Serandrei Barbero, R., Asioli, A., Capraro, L., Fornaciari, E., Vergerio, P.., 2004. The environment of Venice area in the past two million years. Palaeogeography, Palaeoclimatology, Palaeoecology 202, 273-308. doi:10.1016/S0031-0182(03)00640-0

Meng, H.-H., Su, T., Huang, Y.-J., Zhu, H., Zhou, Z.-K., 2015. Late Miocene Palaeocarya (Engelhardieae: Juglandaceae) from Southwest China and its biogeographic implications. Journal of Systematics and Evolution 53, 499-511.

Messager, E., Lebreton, V., Marquer, L., Russo-Ermolli, E., Orain, R., Renault-Miskovsky, J., Lordkipanidze, D., Despriée, J., Peretto, C., Arzarello, M., 2011. Palaeoenvironments of early hominins in temperate and Mediterranean Eurasia: new palaeobotanical data from 
Palaeolithic key-sites and synchronous natural sequences. Quaternary Science Reviews 30, 1439-1447. doi:10.1016/j.quascirev.2010.09.008

Moscariello, A., Ravazzi, C., Brauer, A., Mangili, C., Chiesa, S., Rossi, S., de Beaulieu, J.-L., Reille, M., 2000. A long lacustrine record from the Piànico-Sèlere basin (Middle-Late Pleistocene, Northern Italy). Quaternary International 73, 47-68.

Müllenders, W., Favero, V., Coremans, M., Dirickx, M., 1996. Analyses polliniques des sondages à Venise (VE1, VE1bis, VE2). Aardkundige Mededelingen 7, 87-117.

Munno, R., Petrosino, P., Romano, P., Russo Ermolli, E., Juvigné, É., 2001. A late Middle Pleistocene climatic cycle in southern Italy inferred from pollen analysis and tephrostratigraphy of the Acerno lacustrine succession. Géographie physique et Quaternaire 55, 87-99.

Muñoz Sobrino, C.M., Ramil-Rego, P., Guitián, M.A.R., 2001. Vegetation in the mountains of northwest Iberia during the last glacial-interglacial transition. Vegetation History and Archaeobotany 7-21.

Muttoni, G., Carcano, C., Garzanti, E., Ghielmi, M., Piccin, A., Pini, R., Rogledi, S., Sciunnach, D., 2003. Onset of major Pleistocene glaciations in the Alps. Geology 31, 989-992.

Muttoni, G., Ravazzi, C., Breda, M., Pini, R., Laj, C., Kissel, C., Mazaud, A., Garzanti, E., 2007. Magnetostratigraphic dating of an intensification of glacial activity in the southern Italian Alps during Marine Isotope Stage 22. Quaternary Research 67, 161-173. doi:10.1016/j.yqres.2006.07.006

Nakagawa, T., Garfi, G., Reille, M., Verlaque, R., 1998. Pollen morphology of Zelkova sicula (Ulmaceae), a recently discovered relic species of the European Tertiary flora: description, chromosomal relevance, and palaeobotanical significance. Review of Palaeobotany and Palynology 100, 27-37.

O'Brien, C.E., Jones, R.L., 2003. Early and Middle Pleistocene vegetation history of the Médoc region, southwest France. Journal of Quaternary Science 18, 557-579. doi:10.1002/jqs.779

Okuda, M., Van Vugt, N., Nakagawa, T., Ikeya, M., Hayashida, A., Yasuda, Y., Setoguchi, T., 2002. Palynological evidence for the astronomical origin of lignite-detritus sequence in the Middle Pleistocene Marathousa Member, Megalopolis, SW Greece. Earth and Planetary Science Letters 201, 143-157.

Okuda, M., Yasuda, Y., Setoguchi, T., 2001. Middle to Late Pleistocene vegetation history and climatic changes at Lake Kopais, Southeast Greece. Boreas 30, 73-82.

Oldfield, F., 1968. The Quaternary Vegetational History of the French Pays Basque. I. Stratigraphy and pollen analysis. New Phytologist 67, 677-731. doi:10.1111/j.14698137.1968.tb05494.x

Orain, R., Lebreton, V., Ermolli, E.R., Combourieu-Nebout, N., Sémah, A.-M., 2013. Carya as marker for tree refuges in southern Italy (Boiano basin) at the Middle Pleistocene. Palaeogeography, Palaeoclimatology, Palaeoecology 369, 295-302. doi:10.1016/j.palaeo.2012.10.037

Orain, R., Russo Ermolli, E., Lebreton, V., Di Donato, V., Bahain, J.-J., Sémah, A.-M., 2015. Vegetation sensitivity to local environmental factors and global climate changes during the Middle Pleistocene in southern Italy-A case study from the Molise Apennines. Review of Palaeobotany and Palynology 220, 69-77. doi:10.1016/j.revpalbo.2015.05.002 
Öztürk, M., Çelik, A., Güvensen, A., Hamzaoğlu, E., 2008. Ecology of tertiary relict endemic Liquidambar orientalis Mill. forests. Forest Ecology and Management 256, 510-518. doi:10.1016/j.foreco.2008.01.027

Palombo, M.R., Mussi, M., Agostini, S., Barbieri, M., Di Canzio, E., Di Rita, F., Fiore, I., lacumin, P., Magri, D., Speranza, F., Tagliacozzo, A., 2010. Human peopling of Italian intramontane basins: The early Middle Pleistocene site of Pagliare di Sassa (L'Aquila, central Italy). Quaternary International 223-224, 170-178. doi:10.1016/j.quaint.2009.10.038

Pastre, J.-F., Gauthier, A., Nomade, S., Orth, P., Andrieu, A., Goupille, F., Guillou, H., Kunesch, S., Scaillet, S., Renne, P.R., 2007. The Alleret maar (Massif Central, France): A new lacustrine sequence of the early Middle Pleistocene in western Europe. Comptes Rendus Geoscience 339, 987-997. doi:10.1016/j.crte.2007.09.019

Petrosino, P., Ermolli, E.R., Donato, P., Jicha, B., Robustelli, G., Sardella, R., 2014. Using Tephrochronology and palynology to date the MIS 13 lacustrine sediments of the Mercure basin (Southern Apennines-Italy). Italian Journal of Geosciences 133, 169-186.

Pieruccini, P., Di Celma, C., Di Rita, F., Magri, D., Carnevale, G., Farabollini, P., Ragaini, L., Caffau, M., 2016. Sedimentology, faunal content and pollen record of Middle Pleistocene palustrine and lagoonal sediments from the Peri-Adriatic basin (Abruzzi, eastern central Italy). Quaternary Research in press.

Pini, R., Ravazzi, C., Donegana, M., 2009. Pollen stratigraphy, vegetation and climate history of the last $215 \mathrm{ka}$ in the Azzano Decimo core (plain of Friuli, north-eastern Italy). Quaternary Science Reviews 28, 1268-1290. doi:10.1016/j.quascirev.2008.12.017

Pini, R., Ravazzi, C., Orombelli, G., 2003. Le “Argille sotto il Ceppo"di Paderno d'Adda: nuovi dati palinologici e biostratigrafici. Istituto Lombardo Rendiconti di Scienze B 136, 93-122.

Pini, R., Ravazzi, C., Reimer, P.J., 2010. The vegetation and climate history of the last glacial cycle in a new pollen record from Lake Fimon (southern Alpine foreland, N-Italy). Quaternary Science Reviews 29, 3115-3137. doi:10.1016/j.quascirev.2010.06.040

Pinti, D.L., Quidelleur, X., Chiesa, S., Ravazzi, C., Gillot, P.-Y., 2001. K-Ar dating of an early Middle Pleistocene distal tephra in the interglacial varved succession of Piànico-Sèllere (Southern Alps, Italy). Earth and Planetary Science Letters 188, 1-7. doi:10.1016/S0012821X(01)00305-3

Piotti, A., Leonarduzzi, C., Bagnoli, F., Spanu, I., Brousseau, L., Urbinati, C., Leonardi, S., Vendramin, G.G., 2016. Unexpected scenarios from Mediterranean refugial areas: disentangling complex demographic dynamics along the Apennine distribution of silver fir. Journal of Biogeography in press.

Pons, A., Reille, M., 1988. The Holocene-and Upper Pleistocene pollen record from Padul (Granada, Spain): a new study. Palaeogeography, Palaeoclimatology, Palaeoecology 66, 243-263.

Pontini, M.R., Bertini, A., 2000. Late Pliocene vegetation and climate in Central Italy: high-resolution pollen analysis from the Fosso Bianco succession (Tiberino Basin). Geobios 33, 519-526.

Popescu, S.-M., Biltekin, D., Winter, H., Suc, J.-P., Melinte-Dobrinescu, M.C., Klotz, S., Rabineau, M., Combourieu-Nebout, N., Clauzon, G., Deaconu, F., 2010. Pliocene and Lower Pleistocene vegetation and climate changes at the European scale: Long pollen records and climatostratigraphy. Quaternary International 219, 152-167. doi:10.1016/j.quaint.2010.03.013 
Postigo Mijarra, J.M., Barrón, E., Gómez Manzaneque, F., Morla, C., 2009. Floristic changes in the Iberian Peninsula and Balearic Islands (south-west Europe) during the Cenozoic. Journal of Biogeography 36, 2025-2043. doi:10.1111/j.1365-2699.2009.02142.x

Postigo Mijarra, J.M., Burjachs, F., Gómez Manzaneque, F., Morla, C., 2007. A palaeoecological interpretation of the lower-middle Pleistocene Cal Guardiola site (Terrassa, Barcelona, NE Spain) from the comparative study of wood and pollen samples. Review of Palaeobotany and Palynology 146, 247-264. doi:10.1016/j.revpalbo.2007.05.003

Postigo Mijarra, J.M., Gómez Manzaneque, F., Morla, C., 2008. Survival and long-term maintenance of tertiary trees in the Iberian Peninsula during the Pleistocene: first record of Aesculus L. (Hippocastanaceae) in Spain. Vegetation History and Archaeobotany 17, 351-364. doi:10.1007/s00334-007-0130-x

Postigo-Mijarra, J.M., Morla, C., Barrón, E., Morales-Molino, C., García, S., 2010. Patterns of extinction and persistence of Arctotertiary flora in Iberia during the Quaternary. Review of Palaeobotany and Palynology 162, 416-426. doi:10.1016/j.revpalbo.2010.02.015

Pross, J., Koutsodendris, A., Christanis, K., Fischer, T., Fletcher, W.J., Hardiman, M., Kalaitzidis, S., Knipping, M., Kotthoff, U., Milner, A.M., Müller, U.C., Schmiedl, G., Siavalas, G., Tzedakis, P.C., Wulf, S., 2015. The 1.35-Ma-long terrestrial climate archive of Tenaghi Philippon, northeastern Greece: Evolution, exploration, and perspectives for future research. Newsletters on Stratigraphy 48, 253-276. doi:10.1127/nos/2015/0063

Ramil-Rego, P., Muñoz-Sobrino, C., Rodríguez-Guitián, M., Gómez-Orellana, L., 1998. Differences in the vegetation of the North Iberian Peninsula during the last 16,000 years. Plant Ecology 138, 41-62.

Ramos, J., Bernal, D., Dominguezbella, S., Calado, D., Ruiz, B., Gil, M., Clemente, I., Duran, J., Vijande, E., Chamorro, S., 2008. The Benzú rockshelter: a Middle Palaeolithic site on the North African coast. Quaternary Science Reviews 27, 2210-2218. doi:10.1016/j.quascirev.2008.08.030

Ravazzi, C., 2003. Gli antichi bacini lacustri e i fossili di Leffe, Ranica e Pianico-Sèllere (Prealpi Lombarde). CNR Consiglio Nazionale delle Ricerche, Istituto per la dinamica dei processi ambientali.

Ravazzi, C., 1994. Polline fossile di Aesculus aff. hippocastanum L. nel Bacino di Leffe (Pleistocene inferiore). Posizione sistematica e significato paleoecologico. Giornale botanico italiano 128, 751-770. doi:10.1080/11263509409430319

Ravazzi, C., Burg, van der, 1995. Coniferous woods in the Early Pleistocene brown coals of the Leffe Basin (Lombardy, Italy). Rivista Italiana di Paleontologia e di Stratigrafia 100, 597-620.

Ravazzi, C., Donegana, M., Vescovi, E., Arpenti, E., Caccianiga, M., Kaltenrieder, P., Londeix, L., Marabini, S., Mariani, S., Pini, R., Vai, G.B., Wick, L., 2006. A new Late-glacial site with Picea abies in the northern Apennine foothills: an exception to the model of glacial refugia of trees. Vegetation History and Archaeobotany 15, 357-371. doi:10.1007/s00334-006-00559

Ravazzi, C., Pini, R., Breda, M., Martinetto, E., Muttoni, G., Chiesa, S., Confortini, F., Egli, R., 2005. The lacustrine deposits of Fornaci di Ranica (late Early Pleistocene, Italian Pre-Alps): stratigraphy, palaeoenvironment and geological evolution. Quaternary International 131, 35-58. doi:10.1016/j.quaint.2004.07.021 
Ravazzi, C., Rossignol Strick, M., 1995. Vegetation change in a climatic cycle of Early Pleistocene age in the Leffe Basin (Northern Italy). Palaeogeography, Palaeoclimatology, Palaeoecology $117,105-122$.

Reid, C., Reid, E.M., 1915. The Pliocene floras of the Dutch-Prussian border. M. Nijhoff, Gravenhage.

Reid, C., Reid, E.M., 1907. Fossil flora of Tegelen-sur-Meuse, near Venloo, in the Province of Limburg, J. Müller. ed, Verhandelingen der Koninklijke Akademie van Wetenschappen te Amsterdam, Afdeeling Natuurkunde. Tweede sectie, d. 13, no. 6. Amsterdam.

Reille, M., 1990. La tourbière de La Borde (Pyrénées orientales, France): un site clé pour l'étude du Tardiglaciaire sud-européen. Comptes rendus de l'Académie des sciences. Série 2, Mécanique, Physique, Chimie, Sciences de l'univers, Sciences de la Terre 310, 823-829.

Reille, M., Beaulieu, J.D., Svobodova, H., Andrieu-Ponel, V., Goeury, C., 2000. Pollen analytical biostratigraphy of the last five climatic cycles from a long continental sequence from the Velay region (Massif Central, France). Journal of Quaternary Science 15, 665-685.

Ricciardi, E., 1965. Analisi polliniche di una serie stratigrafica dei sedimenti lacustri del Pleistocene inferiore nel bacino di Leonessa (Rieti-Italia Centrale). Giornale Botanico Italiano 72, 6282.

Ricciardi, E., 1961. Analisi pollinologica dei sedimenti lacustri lignitiferi di Pietrafitta (Perugia, Italia). Pollen et Spores 3, 325-328.

Rodríguez-Sánchez, F., Guzmán, B., Valido, A., Vargas, P., Arroyo, J., 2009. Late Neogene history of the laurel tree (Laurus L., Lauraceae) based on phylogeographical analyses of Mediterranean and Macaronesian populations. Journal of Biogeography 36, 1270-1281.

Roger, S., Coulon, C., Thouveny, N., Féraud, G., Van Velzen, A., Fauquette, S., Cocheme, J.J., Prevot, M., Verosub, K.L., 2000. ${ }^{40} \mathrm{Ar} /{ }^{39} \mathrm{Ar}$ dating of a tephra layer in the Pliocene Senèze maar lacustrine sequence (French Massif Central): constraint on the age of the RéunionMatuyama transition and implications on paleoenvironmental archives. Earth and Planetary Science Letters 183, 431-440.

Rohais, S., Joannin, S., Colin, J.-P., Suc, J.-P., Guillocheau, F., Eschard, R., 2007. Age and environmental evolution of the syn-rift fill of the southern coast of the Gulf of Corinth (Akrata-Derveni region, Greece). Bulletin de la Société géologique de France 178, 231-243.

Roiron, P., 1983. Nouvelle étude de la macroflore Plio-Pléistocène de Crespià (Catalogne, Espagne). Geobios 16, 687-715.

Roucoux, K.H., Tzedakis, P.C., de Abreu, L., Shackleton, N.J., 2006. Climate and vegetation changes 180,000 to 345,000 years ago recorded in a deep-sea core off Portugal. Earth and Planetary Science Letters 249, 307-325. doi:10.1016/j.epsl.2006.07.005

Roucoux, K.H., Tzedakis, P.C., Frogley, M.R., Lawson, I.T., Preece, R.C., 2008. Vegetation history of the marine isotope stage 7 interglacial complex at loannina, NW Greece. Quaternary Science Reviews 27, 1378-1395. doi:10.1016/j.quascirev.2008.04.002

Russo Ermolli, E., 1994. Analyse pollinique de la succession lacustre pléistocène du Vallo di Diano (Campanie, Italie). Annales de la Société géologique de Belgique 117, 333-354.

Russo Ermolli, E., Aucelli, P.P.C., Di Rollo, A., Mattei, M., Petrosino, P., Porreca, M., Rosskopf, C.M., 2010a. An integrated stratigraphical approach to the Middle Pleistocene succession of the Sessano basin (Molise, Italy). Quaternary International 225, 114-127. doi:10.1016/j.quaint.2009.04.008 
Russo Ermolli, E., Di Donato, V., Martín-Fernández, J.A., Orain, R., Lebreton, V., Piovesan, G., 2015. Vegetation patterns in the Southern Apennines (Italy) during MIS 13: Deciphering pollen variability along a NW-SE transect. Review of Palaeobotany and Palynology 218, 167-183. doi:10.1016/j.revpalbo.2014.11.004

Russo Ermolli, E., Sardella, R., Di Maio, G., Petronio, C., Santangelo, N., 2010b. Pollen and mammals from the late Early Pleistocene site of Saticula (Sant'Agata de' Goti, Benevento, Italy). Quaternary International 225, 128-137. doi:10.1016/j.quaint.2009.06.013

Sabato, L., Bertini, A., Masini, F., Albianelli, A., Napoleone, G., Pieri, P., 2005. The lower and middle Pleistocene geological record of the San Lorenzo lacustrine succession in the Sant'Arcangelo Basin (Southern Apennines, Italy). Quaternary International 131, 59-69. doi:10.1016/j.quaint.2004.07.001

Sadori, L., Giardini, M., Chiarini, E., Mattei, M., Papasodaro, F., Porreca, M., 2010. Pollen and macrofossil analyses of Pliocene lacustrine sediments (Salto river valley, Central Italy). Quaternary International 225, 44-57. doi:10.1016/j.quaint.2009.05.008

Sadori, L., Koutsodendris, A., Panagiotopoulos, K., Masi, A., Bertini, A., Combourieu-Nebout, N., Francke, A., Kouli, K., Joannin, S., Mercuri, A.M., Peyron, O., Torri, P., Wagner, B., Zanchetta, G., Sinopoli, G., Donders, T.H., 2016. Pollen-based paleoenvironmental and paleoclimatic change at Lake Ohrid (south-eastern Europe) during the past $500 \mathrm{ka}$. Biogeosciences 13, 1423-1437. doi:10.5194/bg-13-1423-2016

Sánchez Goñi, M.F., Hannon, G.E., 1999. High-altitude vegetational pattern on the Iberian Mountain Chain (north-central Spain) during the Holocene. The Holocene 9, 39-57.

Sánchez Goñi, M.F., Landais, A., Fletcher, W.J., Naughton, F., Desprat, S., Duprat, J., 2008. Contrasting impacts of Dansgaard-Oeschger events over a western European latitudinal transect modulated by orbital parameters. Quaternary Science Reviews 27, 1136-1151. doi:10.1016/j.quascirev.2008.03.003

Sánchez Goñi, M.F., Loutre, M.F., Crucifix, M., Peyron, O., Santos, L., Duprat, J., Malaizé, B., Turon, J.-L., Peypouquet, J.-P., 2005. Increasing vegetation and climate gradient in Western Europe over the Last Glacial Inception (122-110 ka): data-model comparison. Earth and Planetary Science Letters 231, 111-130. doi:10.1016/j.epsl.2004.12.010

Sanchez Goñi, M.F.S., 1996. Vegetation and sea level changes during the Holocene in the estuary of the Bidasoa (Southern part of the bay of Biscay). Quaternaire 7, 207-219.

Sánchez Goñi, M.S., Eynaud, F., Turon, J., Shackleton, N., 1999. High resolution palynological record off the Iberian margin: direct land-sea correlation for the Last Interglacial complex. Earth and Planetary Science Letters 171, 123-137.

Sánchez-Goñi, M.F., 1992. Analyse palynologique de sites préhistoriques de Pays Basque: prémiers résultats pour les grottes de Lezetxiki et Urtiaga. The late Quaternary in the western Pyrenean region. Universidad del País Vasco 207-233.

Sánchez-Goñi, M.-F., Cacho, I., Turon, J.L., Guiot, J., Sierro, F.J., Peypouquet, J.-P., Grimalt, J.O., Shackleton, N.J., 2002. Synchroneity between marine and terrestrial responses to millennial scale climatic variability during the last glacial period in the Mediterranean region. Climate Dynamics 19, 95-105. doi:10.1007/s00382-001-0212-x

Sefidi, K., Marvie Mohadjer, M.R., Etemad, V., Copenheaver, C.A., 2011. Stand characteristics and distribution of a relict population of Persian ironwood (Parrotia persica C.A. Meyer) in 
northern Iran. Flora - Morphology, Distribution, Functional Ecology of Plants 206, 418-422. doi:10.1016/j.flora.2010.11.005

Šercelj, A., 1965. Lower Pleistocene flora from Bukovica near Ilirska Bistrica. Slovenska Akademija Znanosti in Umetnosti 8, 439-470.

Šercelj, A., 1961. The lower Pleistocene vegetation from Zalog near Novo Mesto. Slovenska Akademija Znanosti in Umetnosti 6, 417-434.

Shatilova, I., Mchedlishvili, N., Rukhadze, L., Kvavadze, E., 2011. The history of the flora and vegetation of Georgia (South Caucasus). Georgian national museum, Tbilisi.

Sheykholislami, A., Ahmadi, T., 2009. The Study of Caucasian Walnut (Pterocarya frexinifolia (Lam.) Spach.) in Forests of Mashelak (Noshahr, Iran). Botany Research Journal 2, 28-33.

Sivak, J., 1976. Nouvelles espèces du genre Cathaya d'après leurs grains de pollen dans le tertiaire du sud de la France. Pollen et spores 18, 243-288.

Slimani, S., Derridj, A., Gutierrez, E., 2014. Ecological response of Cedrus atlantica to climate variability in the Massif of Guetiane (Algeria). Forest Systems 23, 448. doi:10.5424/fs/2014233-05175

Stewart, J.R., Lister, A.M., 2001. Cryptic northern refugia and the origins of the modern biota. Trends in Ecology \& Evolution 16, 608-613.

Su, T., Liu, Y.-S. (Christopher), Jacques, F.M.B., Huang, Y.-J., Xing, Y.-W., Zhou, Z.-K., 2013. The intensification of the East Asian winter monsoon contributed to the disappearance of Cedrus (Pinaceae) in southwestern China. Quaternary Research 80, 316-325. doi:10.1016/j.yqres.2013.07.001

Subally, D., Bilodeau, G., Hillaire-Marcel, C., Tamrat, E., Ferry, S., Debard, E., 1999. Cyclic climatic records during the Olduval subchron (Uppermost Pliocene) on Zakynthos Island (Ionian Sea). Geobios 32, 793-803.

Suc, J.-P., 1984. Origin and evolution of the Mediterranean vegetation and climate in Europe. Nature 307, 429-432. doi:10.1038/307429a0

Suc, J.P., 1978. Analyse pollinique de dépôts plio-pléistocènes du sud du massif basaltique de I'Escandorgue (site de Bernasso, Lunas, Hérault, France). Pollen et Spores 20, 497-512.

Suc, J.P., 1973. Etude palynologique des marnes de Celleneuve (Pléistocène inférieur). Hérault. Bulletin de l'Association française pour l'étude du quaternaire 10, 13-24. doi:10.3406/quate.1973.1214

Suc, J.-P., Combourieu-Nebout, N., Seret, G., Popescu, S.-M., Klotz, S., Gautier, F., Clauzon, G., Westgate, J., Insinga, D., Sandhu, A.S., 2010. The Crotone series: A synthesis and new data. Quaternary International 219, 121-133. doi:10.1016/j.quaint.2010.01.008

Suc, J.-P., Cravatte, J., 1982. Étude palynologique du Pliocène de Catalogne (nord-est de l'Espagne): apports à la connaissance de l'histoire climatique de la Méditerranée occidentale et implications chronostratigraphiques. Paléobiologie continentale 13, 1-31.

Suc, J.-P., Drivaliari, A., 1991. Transport of bisaccate coniferous fossil pollen grains to coastal sediments: An example from the earliest Pliocene Orb ria (Languedoc, southern France). Review of Palaeobotany and Palynology 70, 247-253. doi:10.1016/0034-6667(91)90006-O 
Suc, J.-P., Popescu, S.-M., 2005. Pollen records and climatic cycles in the North Mediterranean region since 2.7 Ma. Geological Society, London, Special Publications 247, 147-158. doi:10.1144/GSL.SP.2005.247.01.08

Svenning, J.-C., 2003. Deterministic Plio-Pleistocene extinctions in the European cool-temperate tree flora. Ecology Letters 6, 646-653.

Svenning, J.-C., Eiserhardt, W.L., Normand, S., Ordonez, A., Sandel, B., 2015. The Influence of Paleoclimate on Present-Day Patterns in Biodiversity and Ecosystems. Annual Review of Ecology, Evolution, and Systematics 46, 551-572. doi:10.1146/annurev-ecolsys-112414054314

Tallantire, P.A., 2002. The early-Holocene spread of hazel (Corylus avellana L.) in Europe north and west of the Alps: an ecological hypothesis. The Holocene 12, 81-96. doi:10.1191/0959683602hl523rr

Tzedakis, P., Frogley, M., Heaton, T., 2003. Last Interglacial conditions in southern Europe: evidence from loannina, northwest Greece. Global and Planetary Change 36, 157-170.

Tzedakis, P.C., 1999. The last climatic cycle at Kopais, central Greece. Journal of the Geological Society $156,425-434$.

Tzedakis, P.C., 1994. Vegetation change through glacial-interglacial cycles: a long pollen sequence perspective. Philosophical Transactions of the Royal Society of London B: Biological Sciences 345, 403-432.

Tzedakis, P.C., Emerson, B.C., Hewitt, G.M., 2013. Cryptic or mystic? Glacial tree refugia in northern Europe. Trends in Ecology \& Evolution 28, 696-704. doi:10.1016/j.tree.2013.09.001

Tzedakis, P.C., Hooghiemstra, H., Pälike, H., 2006. The last 1.35 million years at Tenaghi Philippon: revised chronostratigraphy and long-term vegetation trends. Quaternary Science Reviews 25, 3416-3430. doi:10.1016/j.quascirev.2006.09.002

Tzedakis, P.C., Margari, V., Hodell, D.A., 2015. Coupled ocean-land millennial-scale changes 1.26millionyears ago, recorded at Site U1385 off Portugal. Global and Planetary Change 135, 83-88. doi:10.1016/j.gloplacha.2015.10.008

Urban, B., Arias, C., Bigazzi, G., Bonadonna, F., 1983. Early Pleistocene Palynostratigraphy of Fornace Tini, Valle Ricca (central Italy). Palaeogeography, Palaeoclimatology, Palaeoecology 41, 153-164.

Uzquiano, P., 1995. La disparition de Picea à la fin du Pléistocène supérieur en région cantabrique d'après l'anthracoanalyse: déterminisme climatique et anthropique. Comptes rendus de l'Académie des sciences. Série 2. Sciences de la terre et des planètes 321, 545-551.

Van der Wiel, A., Wijmstra, T., 1987a. Palynology of the 112.8-197.8 m interval of the core Tenaghi Philippon III, Middle Pleistocene of Macedonia. Review of Palaeobotany and Palynology 52, 89-117.

Van der Wiel, A., Wijmstra, T., 1987b. Palynology of the lower part (78-120 m) of the core Tenaghi Philippon II, Middle Pleistocene of Macedonia, Greece. Review of Palaeobotany and Palynology 52, 73-88.

van Kolfschoten, T., Markova, A.K., 2005. Response of the European mammalian fauna to the midPleistocene transition. Geological Society, London, Special Publications 247, 221-229.

Velitzelos, D., Bouchal, J.M., Denk, T., 2014. Review of the Cenozoic floras and vegetation of Greece. Review of Palaeobotany and Palynology 204, 56-117. doi:10.1016/j.revpalbo.2014.02.006 
Vieira, M.C.M., 2009. Palinologia do Pliocénico da Orla Ocidental Norte e Centro de Portugal: Contributo para a compreensão da cronostratigrafia e da evolução paleoambiental (PhD Thesis). Universidad do Minho, Braga, Portugal.

Villalta, J. de, Vicente, J., 1972. Una flora del Cuaternario antiguo en las cercanías de Crespià. Acta geológica hispánica 7, 120-128.

Wagner, B., Lotter, A.F., Nowaczyk, N., Reed, J.M., Schwalb, A., Sulpizio, R., Valsecchi, V., Wessels, M., Zanchetta, G., 2009. A 40,000-year record of environmental change from ancient Lake Ohrid (Albania and Macedonia). Journal of Paleolimnology 41, 407-430. doi:10.1007/s10933-008-9234-2

Wagner, B., Wilke, T., Krastel, S., Zanchetta, G., Sulpizio, R., Reicherter, K., Leng, M.J., Grazhdani, A., Trajanovski, S., Francke, A., Lindhorst, K., Levkov, Z., Cvetkoska, A., Reed, J.M., Zhang, X., Lacey, J.H., Wonik, T., Baumgarten, H., Vogel, H., 2014. The SCOPSCO drilling project recovers more than 1.2 million years of history from Lake Ohrid. Scientific Drilling 17, 1929. doi:10.5194/sd-17-19-2014

Wang, Y.-F., Li, C.-S., Collinson, M.E., Lin, J., Sun, Q.-G., 2003. Eucommia (Eucommiaceae), a potential biothermometer for the reconstruction of paleoenvironments. American journal of botany 90, 1-7.

West, R., 1970. Pleistocene history of the British flora, in: D. Walker and R.G. West (Eds) Studies in the Vegetational History of the British Isles. Cambridge University Press, pp. 1-11.

West, R., 1962. Vegetational history of the Early Pleistocene of the Royal Society borehole at Ludham, Norfolk. Proceedings of the Royal Society of London B: Biological Sciences 155, 437-453.

Wijmstra, T., 1969. Palynology of the first 30 metres of a $120 \mathrm{~m}$ deep section in northern Greece. Acta Botanica Neerlandica 18, 511-527.

Wijmstra, T., Smit, A., 1976. Palynology of the middle part (30-78 metres) of the $120 \mathrm{~m}$ deep section in northern Greece (Macedonia). Acta Botanica Neerlandica 25, 297-312.

Worth, J.R., Sakaguchi, S., Tanaka, N., Yamasaki, M., Isagi, Y., 2013. Northern richness and southern poverty: contrasting genetic footprints of glacial refugia in the relictual tree Sciadopitys verticillata (Coniferales: Sciadopityaceae). Biological Journal of the Linnean Society 108, 263-277.

Yavuz-Işık, N., 2007. Pollen analysis of coal-bearing Miocene sedimentary rocks from the Seyitömer Basin (Kütahya), Western Anatolia. Geobios 40, 701-708.

YII, E.I., Carrión, J.S., Pantaleón-Cano, J., Dupré, M., La Roca, N., Roure, J.M., Pérez-Obiol, R., 2003. Palinología del Cuaternario reciente en la Laguna de Villena (Alicante). Anales de Biología $25,65-72$.

YII, E.-I., Perez-Obiol, R., Pantaleon-Cano, J., Roure, J.M., 1997. Palynological evidence for climatic change and human activity during the Holocene on Minorca (Balearic Islands). Quaternary Research 48, 339-347.

Zagwijn, W., 1985. An outline of the Quaternary stratigraphy of the Netherlands. Geologie en Mijnbouw 64, 17-24.

Zagwijn, W., De Jong, J., 1984. Die Interglaziale von Bavel und Leerdam und ihre stratigraphische Stellung im niederländischen Früh-Pleistozän. Mededelingen Rijks Geologische Dienst 37, 155-169. 
2440 Zagwijn, W.H., 1974. The Pliocene-Pleistocene boundary in western and southern Europe. Boreas 3, $2441 \quad 75-97$.

2442 Zagwijn, W.H., 1963. Pleistocene stratigraphy in the Netherlands, based on changes in vegetation 2443 and climate. Verh. Kon. Ned. Geol. Mijnbouwk. Gen., Geol. Serie 21-2.

2444 Zagwijn, W.H., 1957. Vegetation, climate and time-correlations in the Early Pleistocene of Europe. 2445 Geologie en Mijnbouw 19, 233-244.

2446 Zanni, M., Ravazzi, C., 2007. Description and differentiation of Pseudolarix amabilis pollen 2447

Palaeoecological implications and new identification key to fresh bisaccate pollen. Review of Palaeobotany and Palynology 145, 35-75. doi:10.1016/j.revpalbo.2006.08.004 
2451 Fig. 1. Location of the Quaternary records considered in this paper. Numbering of the sites follows Table 1. Red dots represent the peri-Iberian marine sites included in Fig. 2; blue dots correspond to the sites from NW Iberia and S France represented in Fig. 2; red squares include sites from $\mathrm{N}$ Italy (Fig. 3); yellow dots correspond to sites from central Italy of Fig. 4; pink dots are sites from S Italy represented in Fig. 4; green dots include Greece and the Aegean (Fig. 4); the blue square corresponds to the site of Tenaghi Philippon (Fig. 5) and the pink square to DSDP site 380 (Fig. 5). White dots indicate the location of sites not represented in Figs 2-5 but cited in the text.

Fig. 2. Stratigraphical setting and schematic pollen biostratigraphy of selected taxa of Pleistocene records from the Alboran Sea and off Portugal, and from NW Iberia and S France. Question marks indicate uncertainties in the chronological setting of the records. Asterisks indicate plant macrofossils. Red lines represent regionally extinct taxa. Blue lines represent taxa that are only mentioned in the papers or uncertain determinations (e.g. Ulmus/Zelkova).

Fig. 3. Stratigraphical setting and schematic pollen biostratigraphy of selected taxa of Pleistocene records from $\mathrm{N}$ Italy $\left(>44^{\circ} \mathrm{N}\right)$ and Central Italy $\left(44^{\circ}-41^{\circ} \mathrm{N}\right)$. Note that the sites of Sessano and Boiano are administratively located in S Italy. Question marks indicate uncertainties in the chronological setting of the records. Asterisks indicate plant macrofossils. Red lines represent regionally extinct taxa. Blue lines represent taxa that are only mentioned in the papers or uncertain determinations (e.g. Ulmus/Zelkova).

Fig. 4. Stratigraphical setting and schematic pollen biostratigraphy of selected taxa of Pleistocene records from S Italy $\left(<41^{\circ} \mathrm{N}\right)$, Greece and the Aegean. Question marks indicate uncertainties in the chronological setting of the records. Asterisks indicate plant macrofossils. Red lines represent regionally extinct taxa. Blue lines represent taxa that are only mentioned in the papers or uncertain determinations (e.g. Ulmus/Zelkova).

Fig. 5. Stratigraphical setting and schematic pollen biostratigraphy of selected taxa of Pleistocene records from Tenaghi Philippon (Tzedakis et al., 2006) and DSDP site 380 (Biltekin et al. 2015). Red lines represent regionally extinct taxa. Blue lines represent taxa that are only mentioned in the papers or uncertain determinations (e.g. Ulmus/Zelkova).

2476 Fig. 6. Schematic stratigraphic distribution of Taxodium type, Sciadopitys, Cathaya type, and Cedrus. Blue lines represent taxa that are only mentioned in the original papers.

2478 Fig. 7. Schematic stratigraphic distribution of Tsuga, Eucommia, Parrotia, and Liquidambar. Blue lines represent taxa that are only mentioned in the original papers.

Fig. 8 Schematic stratigraphic distribution of Engelhardia, Carya, Pterocarya, and Zelkova. Blue lines 


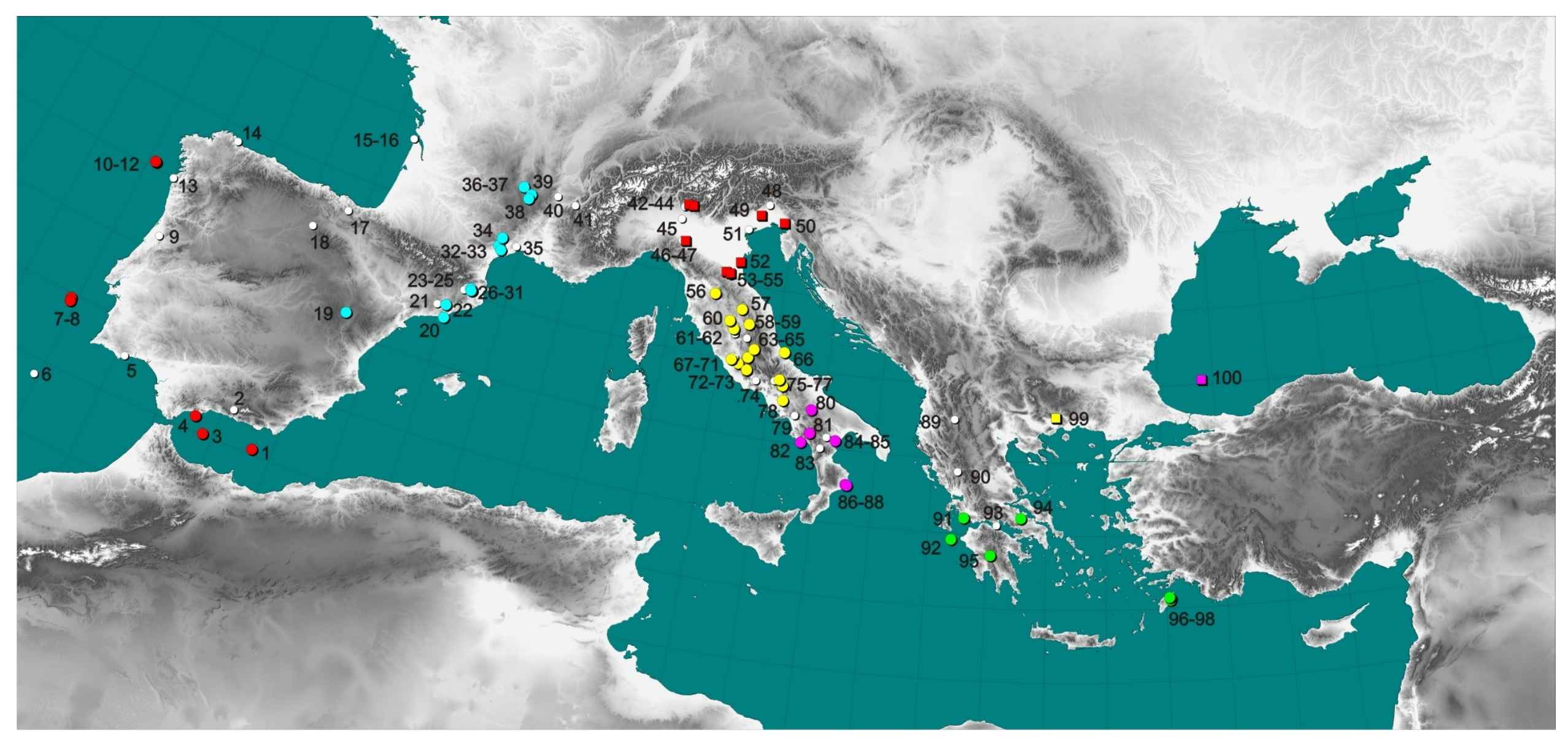




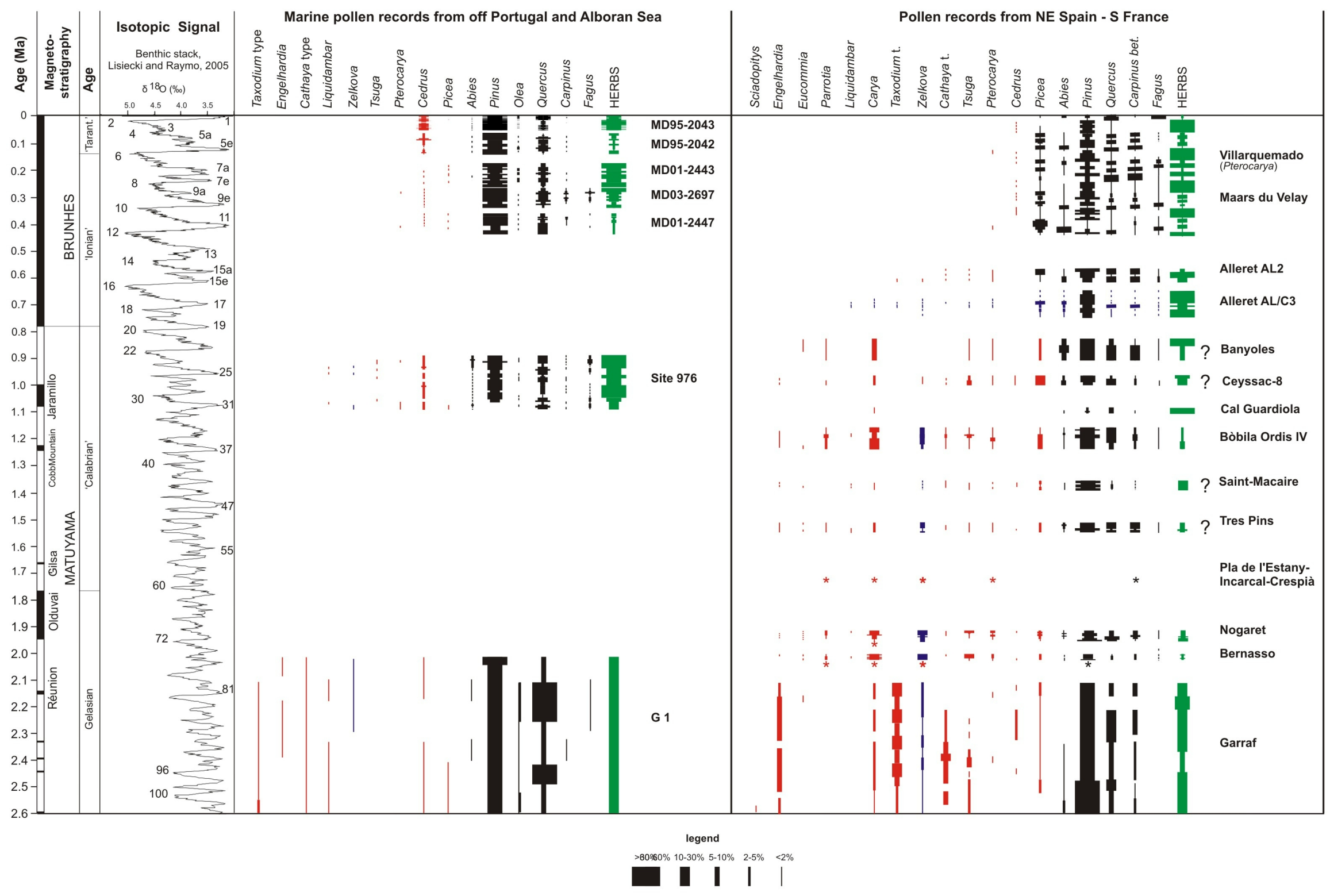




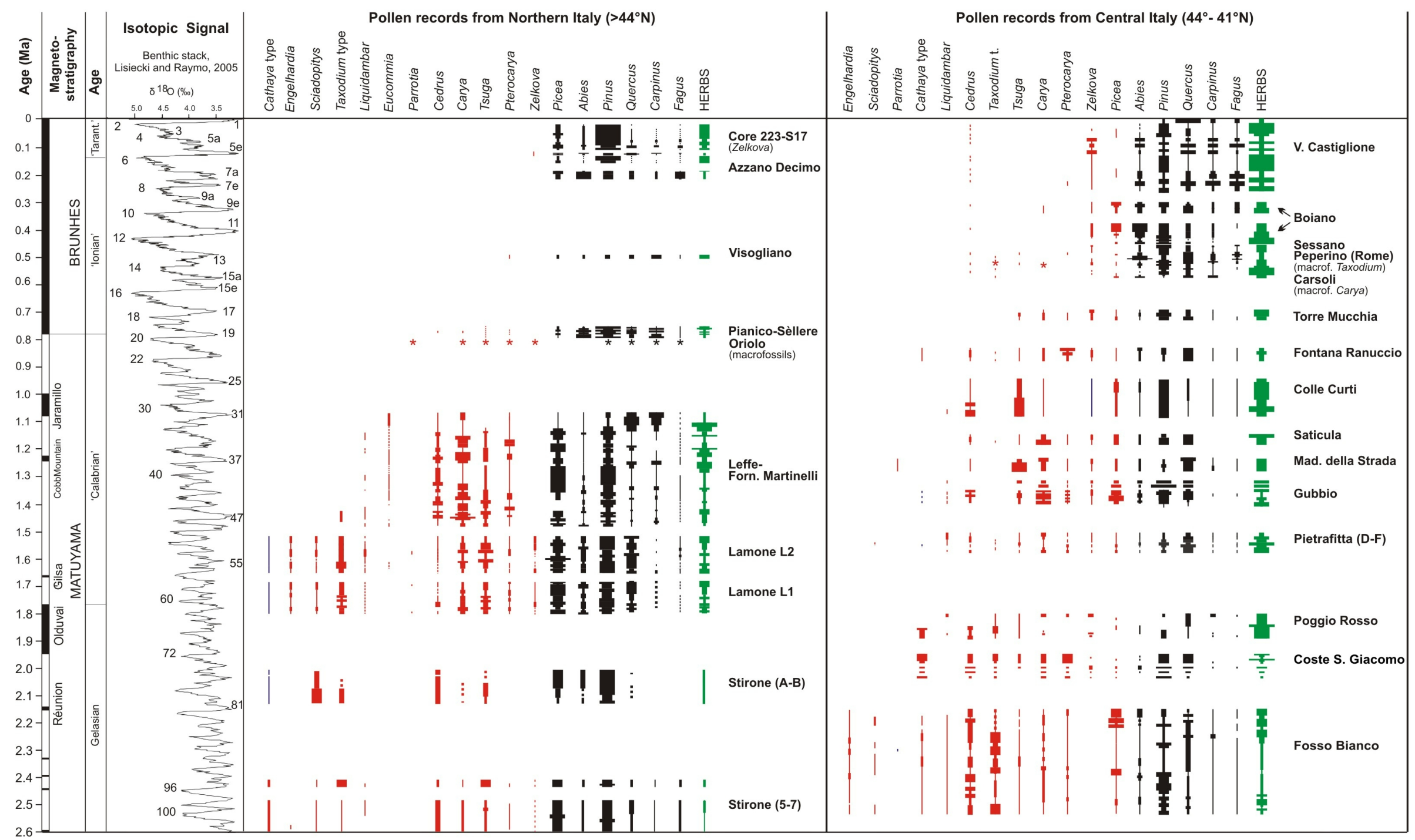

legend

? 


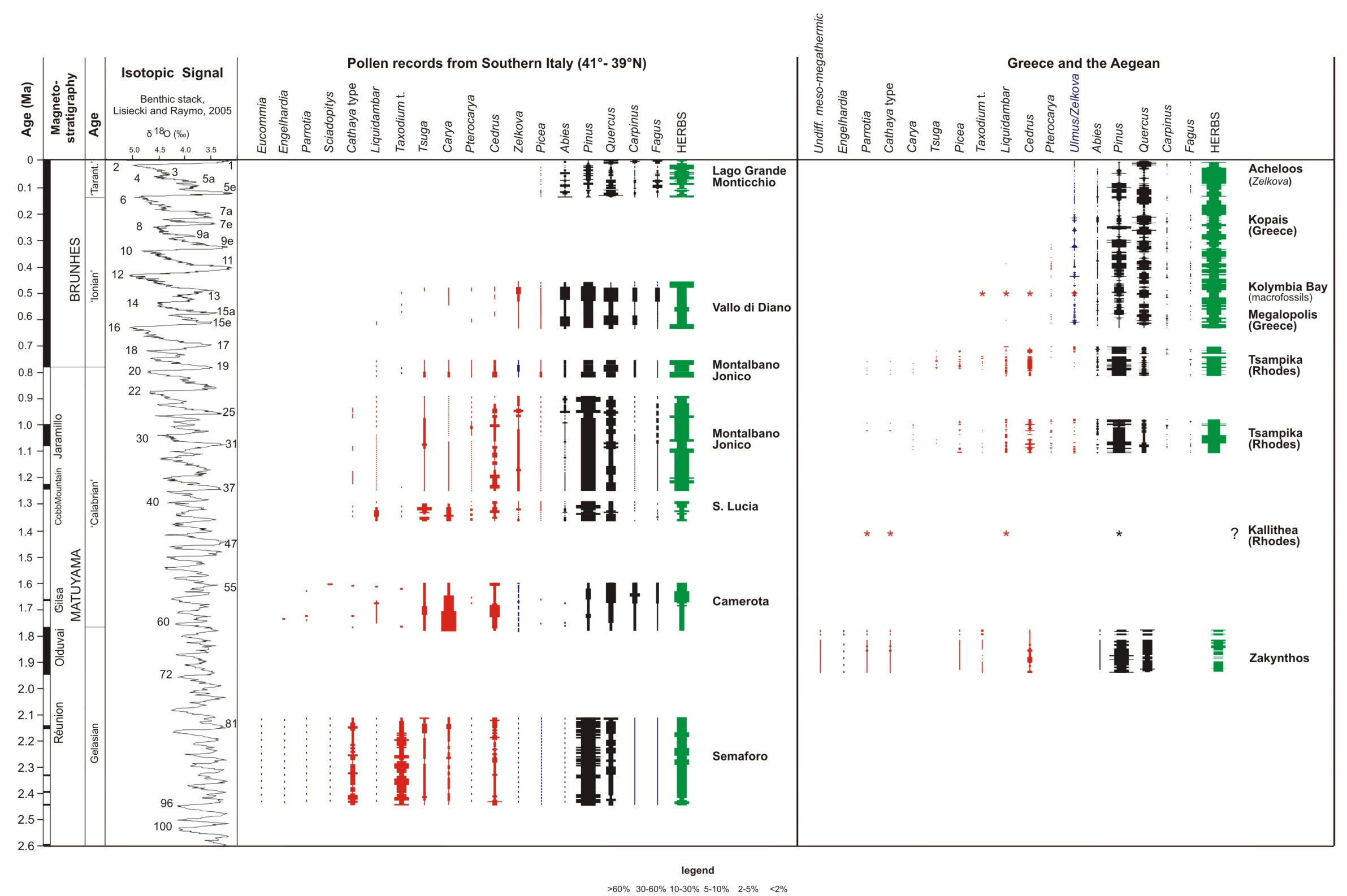

口 1 I I । 


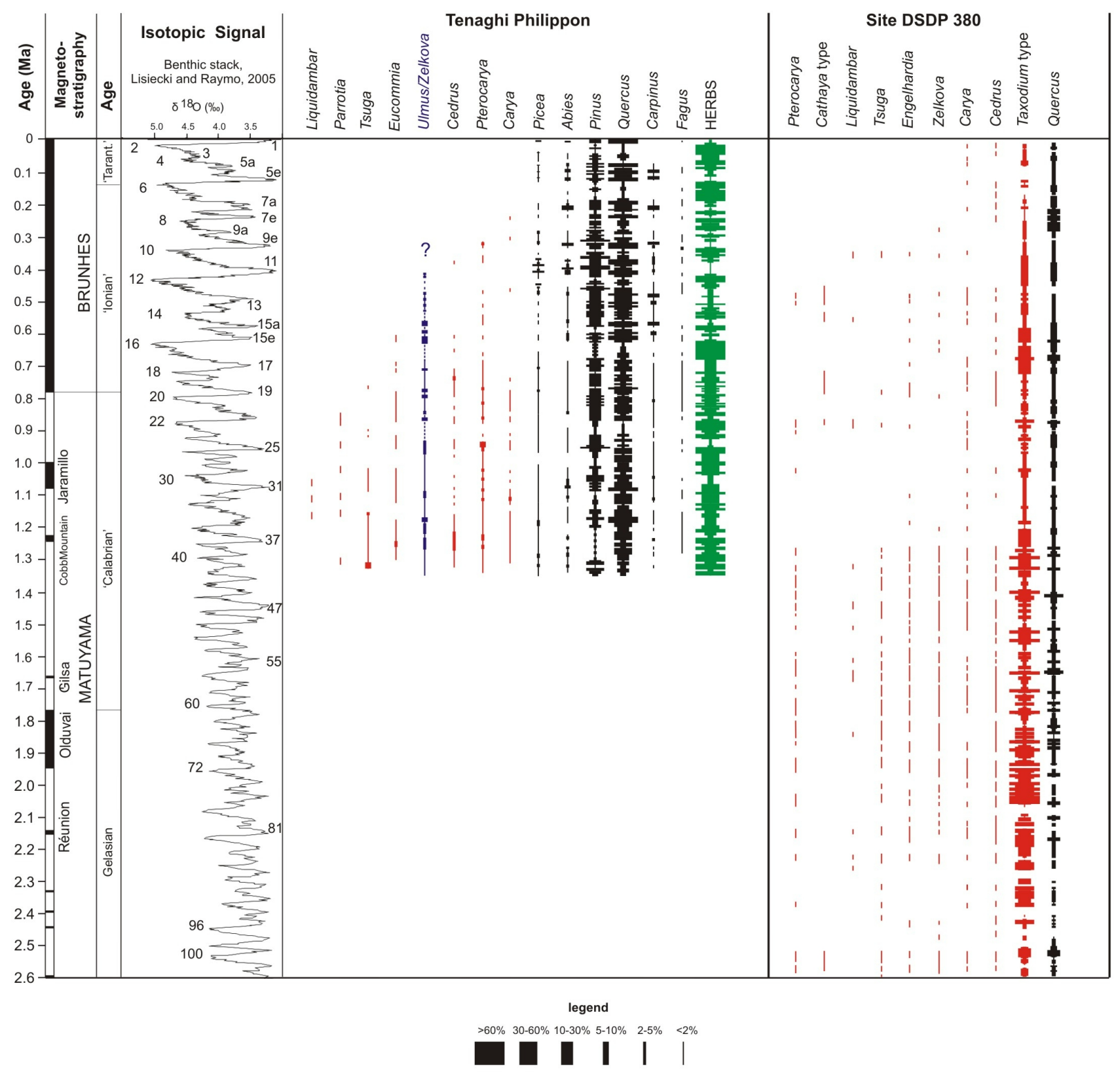




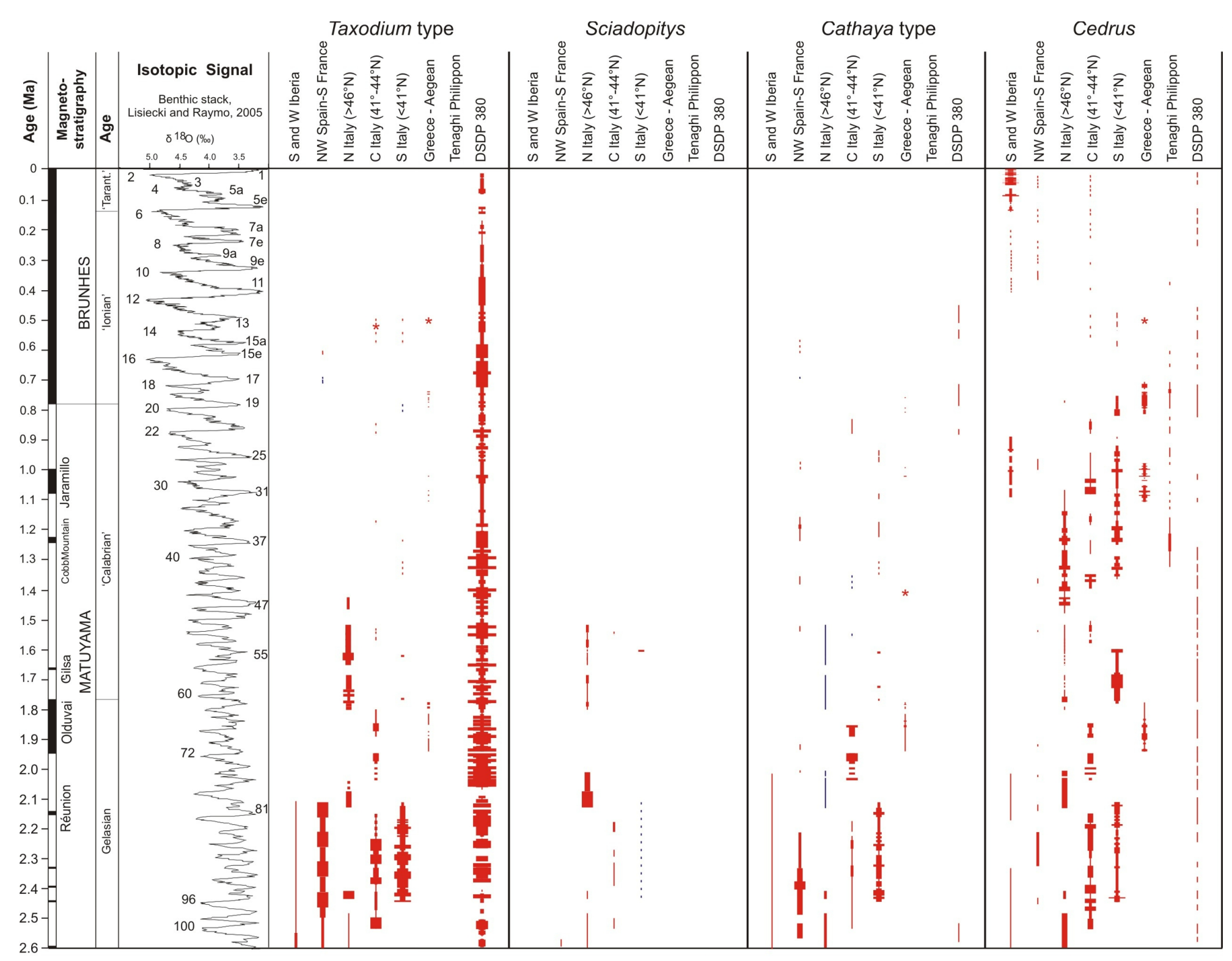

legend

口 


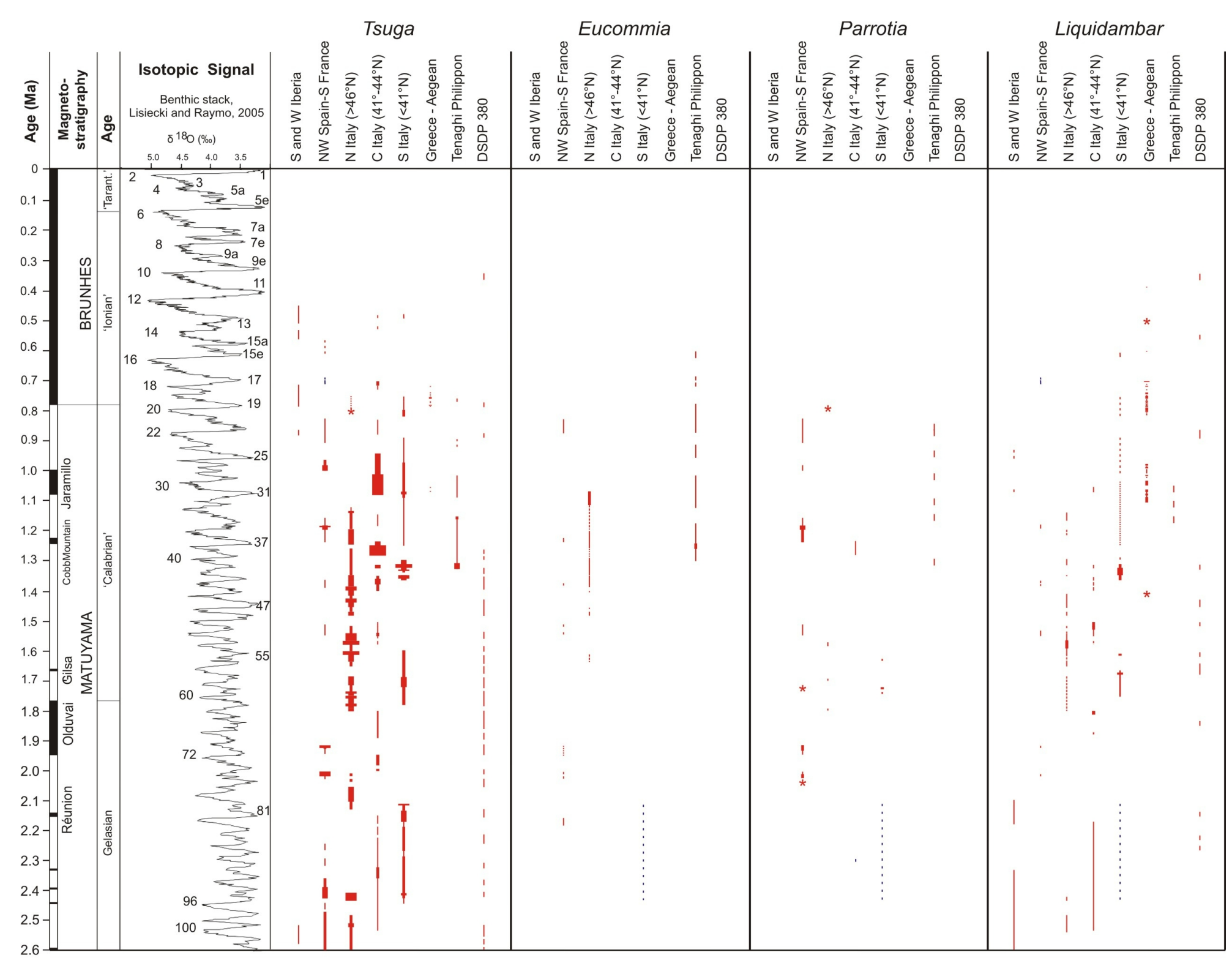

legend

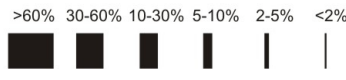




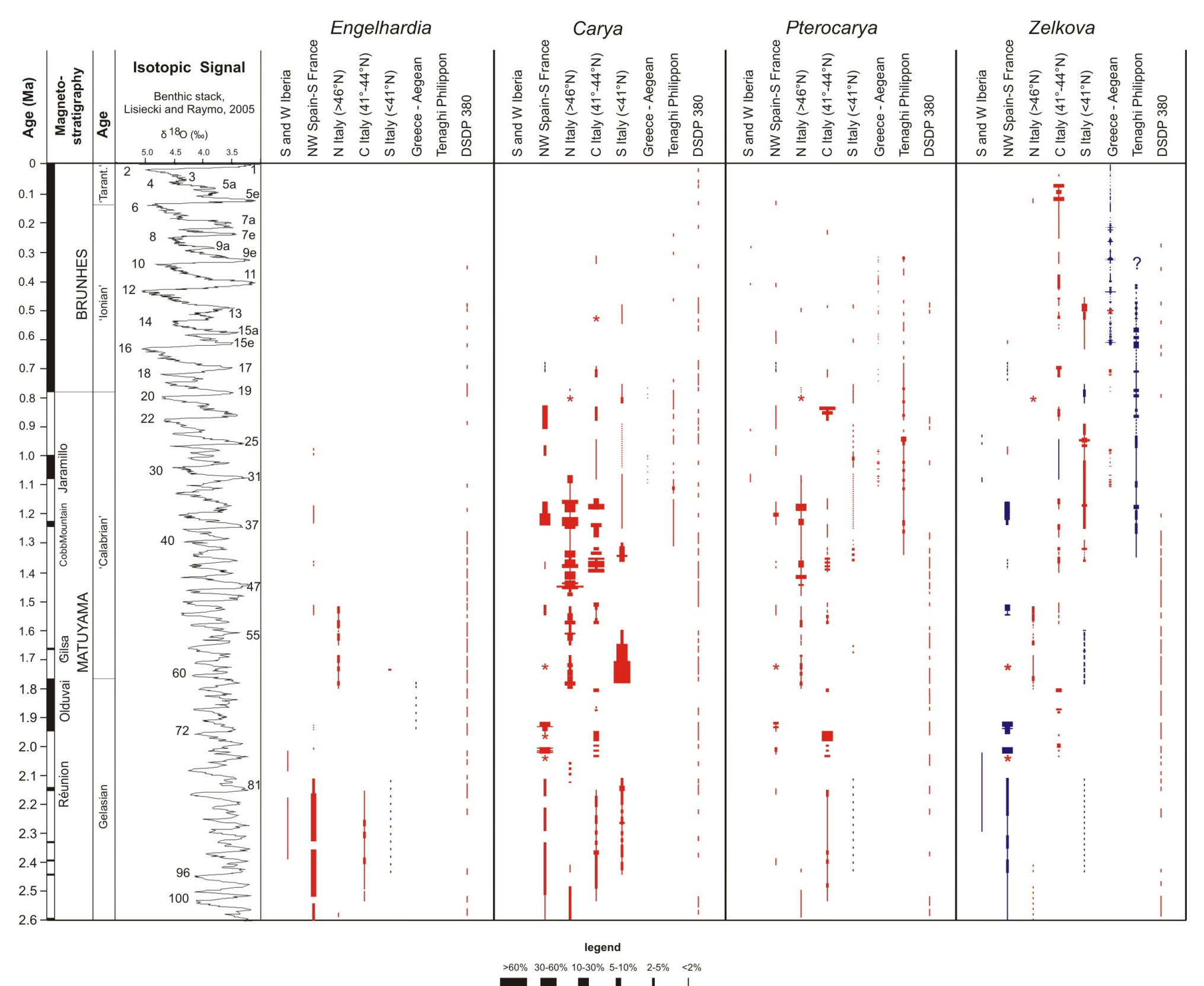

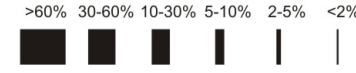


Table 1. List of the vegetation records represented in Fig. 1.

\begin{tabular}{|c|c|c|c|c|c|c|}
\hline $\begin{array}{c}\text { Site } \\
\text { number }\end{array}$ & Site & $\begin{array}{l}\text { Age (ka) } \\
\text { MIS }\end{array}$ & $\begin{array}{l}\text { Pollen (P) } \\
\text { Macrofossil } \\
\text { (M) }\end{array}$ & $\begin{array}{l}\text { Marine (M) } \\
\text { Continental } \\
\text { (C) }\end{array}$ & Chonological control & References \\
\hline 1 & MD95-2043 & $48-2$ ka & $\mathrm{P}$ & M & $14 \mathrm{C}$, event stratigraphy & $\begin{array}{l}\text { Sanchez Goñi et al., 2002; Fletcher } \\
\text { and Sanchez Goñi, } 2008\end{array}$ \\
\hline 2 & Padul & $100-0 \mathrm{ka}$ & $P$ & C & $14 \mathrm{C}$ and vegetation history & Pons and Reille, 1988 \\
\hline 3 & ODP976 & MIS 31-23 & $\mathrm{P}$ & M & Oxygen isotope stratigraphy & $\begin{array}{l}\text { Joannin 2007; Joannin et al., 2011; } \\
\text { Combourieu Nebout et al., } 2009\end{array}$ \\
\hline 4 & Andalucia G1 & $\begin{array}{l}\text { Miocene- } \\
\text { Gelasian }\end{array}$ & $\mathrm{P}$ & M & Oxygen isotope stratigraphy & Feddi et al., 2011 \\
\hline 5 & Morgandinho & $\begin{array}{l}\text { Ealry-Middle } \\
\text { Pleistocene }\end{array}$ & $P$ & C & Micromammals & Antunes et al., 1986 \\
\hline 6 & Site U1385 & MIS 38 & $\mathrm{P}$ & $\mathrm{M}$ & Orbital tuning & Tzedakis et al., 2015 \\
\hline 7 & MD95-2042 & MIS 6-2 & $\mathrm{P}$ & M & $\begin{array}{l}14 \mathrm{C} \text { and Oxygen isotope } \\
\text { stratigraphy }\end{array}$ & Sanchez Goñi et al., 1999 \\
\hline 8 & MD01-2443 & 345-180 ka & $\mathrm{P}$ & $M$ & Oxygen isotope stratigraphy & Roucoux et al., 2006 \\
\hline 9 & Monsarros & $\begin{array}{c}\text { Plio- } \\
\text { Pleistocene }\end{array}$ & $\mathrm{P}$ & C & Stratigraphy & Vieira, 2009 \\
\hline 10 & MD03-2697 & $340-270 \mathrm{ka}$ & $\mathrm{P}$ & M & Oxygen isotope stratigraphy & Desprat et al., 2009 \\
\hline 11 & MD01-2447 & $\begin{array}{c}430-360 ; 250- \\
180 \mathrm{ka}\end{array}$ & $\mathrm{P}$ & M & Oxygen isotope stratigraphy & Desprat et al., 2005 \\
\hline 12 & MD99-2331 & MIS 5-2 & $\mathrm{P}$ & M & $14 \mathrm{C}$, event stratigraphy & Sanchez-Goñi et al., 2005, 2008 \\
\hline 13 & $\begin{array}{l}\text { Santa Maria de } \\
\text { Oia }\end{array}$ & MIS 5-3 & $\mathrm{P}$ & C-M (coastal) & $14 C$, coastal stratigraphy & Gómez-Orellana et al., 2013 \\
\hline 14 & Area Longa & MIS 5-3 & $\mathrm{P}$ & C-M (coastal) & $14 C$, coastal stratigraphy & Gómez-Orellana et al., 2007 \\
\hline 15 & $\begin{array}{l}\text { Pointe de la } \\
\text { Négade North }\end{array}$ & $\begin{array}{c}\text { Early } \\
\text { Pleistocene }\end{array}$ & $\mathrm{P}+\mathrm{M}$ & $M$ & Pollen biostratigraphy & O'Brien and Jones, 2003 \\
\hline 16 & La Balise & MIS 11 & $\mathrm{P}+\mathrm{M}$ & M & Pollen biostratigraphy & O'Brien and Jones, 2003 \\
\hline 17 & Lezetxiki & MIS 3 & $P$ & C & $\begin{array}{l}14 \mathrm{C} \text {, archaeological data (lithic } \\
\text { tools) }\end{array}$ & Sánchez-Goñi, 1992 \\
\hline 18 & Atapuerca & $900-400$ ka & $\mathrm{P}$ & C & Luminiscence & García-Antón \& Sainz-Ollero, 1991 \\
\hline 19 & $\begin{array}{l}\text { Cañizar de } \\
\text { Villaquemado }\end{array}$ & MIS 5-1 & $P$ & C & $14 \mathrm{C}$ and OSL dating & $\begin{array}{l}\text { González-Sampériz et al., 2013; } \\
\text { Aranbarri et al., 2014; García- } \\
\text { Prieto, } 2015\end{array}$ \\
\hline
\end{tabular}




\begin{tabular}{|c|c|c|c|c|c|c|}
\hline 20 & Garraf & $5300-1750 \mathrm{ka}$ & $\mathrm{P}$ & $\mathrm{M}$ & Foraminifer biostratigraphy & Suc and Cravatte, 1982 \\
\hline 21 & Abric Romaní & $70-40 \mathrm{ka}$ & $\mathrm{P}$ & C & $\mathrm{U} / \mathrm{Th}$ & Burjachs et al., 2012 \\
\hline 22 & Cal Guardiola & $1200-800$ ka & P-M & $\mathrm{C}$ & $\begin{array}{l}\text { Micromammals and } \\
\text { palaeomagnetism }\end{array}$ & Postigo Mijarra et al., 2007 \\
\hline 23 & Val d'en Bas & $250 \mathrm{ka}$ & $\mathrm{P}$ & C & Volcanic crust & Cross et al., 1986 \\
\hline 24 & $\begin{array}{l}\text { Pla de l'Estany- } \\
\text { Garrotxa }\end{array}$ & MIS 5?-1 & $\mathrm{P}$ & C & $\begin{array}{l}\text { Vegetation history and } 14 \mathrm{C} \text { for the } \\
\text { upper part }\end{array}$ & Burjachs, 1990 \\
\hline 25 & $\begin{array}{l}\text { Pla de l'Estany- } \\
\text { Incarcal-Crespià }\end{array}$ & $\begin{array}{l}\text { Plio- } \\
\text { Pleistocene }\end{array}$ & M & C & Fauna (Mammals biostratigraphy) & $\begin{array}{l}\text { Villalta and Vicente, 1972; Suc and } \\
\text { Cravatte, 1982; Roiron, } 1983\end{array}$ \\
\hline 26 & Tres Pins & 2600-1200 ka & $\mathrm{P}$ & C & $\begin{array}{l}\text { Vegetation composition (presence } \\
\text { of carya) }\end{array}$ & Leroy, 1997 \\
\hline 27 & Mas Grill & $\begin{array}{c}\text { Mid- } \\
\text { Pleistocene? }\end{array}$ & $\mathrm{P}$ & C & $\begin{array}{l}\text { Vegetation history (older than } \\
\text { Bòbila Ordis) }\end{array}$ & Geurts, 1977; 1979 \\
\hline 28 & Bòbila-Ordis & MIS 36-33 & $\mathrm{P}$ & C & $\begin{array}{l}\text { Micromammals and } \\
\text { palaeomagnetism }\end{array}$ & $\begin{array}{l}\text { Løvlie and Leroy, 1995; Leroy, } \\
2008\end{array}$ \\
\hline 29 & Banyoles & $1000-950 \mathrm{ka}$ & $\mathrm{P}$ & C & & Julia Bruguès and Suc, 1980 \\
\hline 30 & Molí Vell & $\begin{array}{c}\text { Early } \\
\text { Pleistocene }\end{array}$ & $\mathrm{P}$ & C & $\begin{array}{l}\text { Vegetation history (younger than } \\
\text { Bòbila Ordis) }\end{array}$ & Geurts, 1977, 1979 \\
\hline 31 & Mas Miquel & $\begin{array}{c}\text { Early } \\
\text { Pleistocene }\end{array}$ & $\mathrm{P}$ & C & Fauna (Mammals biostratigraphy) & Leroy, 1990 \\
\hline 32 & Saint-Macaire & $1400-700 \mathrm{ka}$ & $\mathrm{P}$ & C & K/Ar dating, magnetostratigraphy & Leroy et al., 1994 \\
\hline 33 & Nogaret & MIS 75 & $\mathrm{P}$ & C & $\begin{array}{l}\text { K/Ar dating, mammal } \\
\text { biostratigraphy }\end{array}$ & $\begin{array}{l}\text { Brugal et al., 1990; Leroy and } \\
\text { Seret, } 1992\end{array}$ \\
\hline 34 & Bernasso & 2160-1960 ka & $\mathrm{P}$ & $\mathrm{C}$ & K/Ar dating, magnetostratigraphy & Suc, 1978; Leroy and Roiron, 1996 \\
\hline 35 & Celleneuve & $\begin{array}{l}\text { Early } \\
\text { Calabrian }\end{array}$ & $\mathrm{P}$ & C-M & Biostratigraphy & Suc, 1973 \\
\hline 36 & Alleret & MIS 17-15 & $\mathrm{P}$ & $\mathrm{C}$ & $\begin{array}{l}\text { Tephrochronology, K/Ar and } \mathrm{Ar} / \mathrm{Ar} \\
\text { dating }\end{array}$ & $\begin{array}{l}\text { Pastre et al., 2007; Degeai et al., } \\
2013\end{array}$ \\
\hline 37 & Senèze & MIS 85-76 & $\mathrm{P}$ & C & $\begin{array}{l}\text { Ar/Ar dating, mammal } \\
\text { biostratigraphy, } \\
\text { magnetostratigraphy }\end{array}$ & Elhaï, 1969; Roger et al., 2000 \\
\hline 38 & Velay maars & $430-0 \mathrm{ka}$ & $\mathrm{P}$ & C & Biostratigraphy, Ar/Ar dating & Reille et al., 2000 \\
\hline 39 & Ceyssac & $1000-900 \mathrm{ka}$ & $\mathrm{P}$ & C & $\mathrm{K} / \mathrm{Ar}$ dating, magnetostratigraphy & Ablin, 1991 \\
\hline 40 & Saint-Vallier & $1900 \mathrm{ka}$ & $\mathrm{P}$ & $\mathrm{C}$ & Biostratigraphy & Argant, 2004 \\
\hline 41 & La Côte & MIS 11 & $\mathrm{P}$ & C & Pollen biostratigraphy & Field et al., 2000 \\
\hline 42 & Fornaci di Ranica & $\begin{array}{l}\text { MIS (36)30 or } \\
28\end{array}$ & $\mathrm{P}, \mathrm{M}$ & C & $\begin{array}{l}\text { Magnetostratigraphy, mammal } \\
\text { biostratigraphy }\end{array}$ & Ravazzi et al., 2005 \\
\hline 43 & $\begin{array}{l}\text { Leffe-Fornace } \\
\text { Martinelli }\end{array}$ & MIS 64-22 & $\mathrm{P}, \mathrm{M}$ & C & $\begin{array}{l}\text { Magnetostratigraphy, mammal } \\
\text { biostratigraphy }\end{array}$ & $\begin{array}{l}\text { Ravazzi and Rossignol-Strick, } \\
\text { 1995; Ravazzi, 2003; Muttoni et al., }\end{array}$ \\
\hline
\end{tabular}




\begin{tabular}{|c|c|c|c|c|c|c|}
\hline & & & & & & 2007 \\
\hline 44 & Pianico Sèllere & MIS 21-19 & $\mathrm{P}, \mathrm{M}$ & C & $\begin{array}{l}\mathrm{K} / \mathrm{Ar} \text { and } \mathrm{Ar} / \mathrm{Ar} \text { dating, mammal } \\
\text { biostratigraphy }\end{array}$ & Ravazzi, 2003; Martinetto, 2009 \\
\hline 45 & Pianengo & $1200-700 \mathrm{ka}$ & $\mathrm{P}$ & C & Magnetostratigraphy & Muttoni et al., 2003 \\
\hline 46 & Stirone & $5100-2200 \mathrm{ka}$ & $\mathrm{P}$ & M & $\begin{array}{l}\text { Mollusc anf foraminifer } \\
\text { biostratigraphy }\end{array}$ & $\begin{array}{l}\text { Lona and Bertoldi, 1972; Bertini, } \\
2001\end{array}$ \\
\hline 47 & Castell'Arquato & $\begin{array}{c}\text { Early } \\
\text { Pleistocene }\end{array}$ & $\mathrm{P}$ & M & Mollusc biostratigraphy & Lona and Bertoldi, 1972 \\
\hline 48 & $\begin{array}{l}\text { San Pietro di } \\
\text { Ragogna }\end{array}$ & Gelasian & $\mathrm{P}, \mathrm{M}$ & C & Lithostratigraphy, biostratigraphy & Martinetto et al., 2012 \\
\hline 49 & Azzano Decimo & 215-20 ka & $P$ & C & 14C dating, biostratigraphy & Pini et al., 2009 \\
\hline 50 & Visogliano & MIS 13 or 11 & $\mathrm{P}$ & M & Mammal biostratigraphy & $\begin{array}{l}\text { Cattani et al., 1991; Abbazzi et al., } \\
2000\end{array}$ \\
\hline 51 & Venice & 2150-110 ka & $\mathrm{P}$ & M & $\begin{array}{l}\text { Magnetostratigraphy, molluscs } \\
\text { biostratigraphy, sapropel } \\
\text { stratigraphy }\end{array}$ & $\begin{array}{l}\text { Mullenders et al., 1996, Massari et } \\
\text { al., } 2004\end{array}$ \\
\hline 52 & Core 223-S17 & $130-0 \mathrm{ka}$ & $\mathrm{P}$ & $\mathrm{C} / \mathrm{M}$ & $\begin{array}{l}\text { Foraminifer and ostracod } \\
\text { biostratigraphy }\end{array}$ & Amorosi et al., 2004 \\
\hline 53 & Oriolo (Faenza) & ca. 800 ka & $\mathrm{M}$ & $\mathrm{C} / \mathrm{M}$ & $\begin{array}{l}\text { Magnetostratigraphy, molluscs } \\
\text { biostratigraphy }\end{array}$ & Martinetto and Sami, 2001 \\
\hline 54 & Lamone Valley & MIS 64-46 & $\mathrm{P}$ & M & $\begin{array}{l}\text { Mollusc and ostracod } \\
\text { biostratigraphy }\end{array}$ & Fusco, 2007 \\
\hline 55 & Monte Poggiolo & $1400-1070 ? \mathrm{ka}$ & $\mathrm{P}$ & M & $\begin{array}{l}\text { Magnetostratigraphy, molluscs } \\
\text { biostratigraphy,ESR dating }\end{array}$ & Messager et al., 2011 \\
\hline 56 & Poggio Rosso & $1900-1800 \mathrm{ka}$ & $\mathrm{P}$ & C & Magnetostratigraphy & Bertini et al., 2010 \\
\hline 57 & Gubbio & $\begin{array}{c}1600-1300 ? \\
\mathrm{Ka}\end{array}$ & $\mathrm{P}$ & C & Biostratigraphy & Lona and Ricciardi, 1961 \\
\hline 58 & Colle Curti & ca. 990 ka & $P$ & C & Magnetostratigraphy & Bertini, 2000 \\
\hline 59 & Cesi & $750-600 ? \mathrm{ka}$ & $\mathrm{P}$ & C & $\begin{array}{l}\text { Magnetostratigraphy, } \\
\text { Tephrochronology }\end{array}$ & Bertini, 2000 \\
\hline 60 & Pietrafitta & $1400 ? \mathrm{ka}$ & $\mathrm{P}$ & C & Mammal biostratigraphy & $\begin{array}{l}\text { Ricciardi, 1961; Martinetto et al., } \\
2014\end{array}$ \\
\hline 61 & Fosso Bianco & MIS 100-82 & $\mathrm{P}$ & C & $\begin{array}{l}\text { Magnetostratigraphy, Mammal } \\
\text { biostratigraphy }\end{array}$ & Pontini and Bertini 2000 \\
\hline 62 & Dunarobba & $3500-1500 ? \mathrm{ka}$ & $\mathrm{P}, \mathrm{M}$ & C & Biostratigraphy & Martinetto et al., 2014 \\
\hline 63 & Leonessa & $1400-1200 ? \mathrm{ka}$ & $\mathrm{P}$ & C & Biostratigraphy & Ricciardi, 1965 \\
\hline 64 & $\begin{array}{l}\text { Madonna della } \\
\text { Strada }\end{array}$ & ca. 1250 ka & $\mathrm{P}$ & C & Mammal biostratigraphy & Magri et al., 2010 \\
\hline 65 & Pagliare di Sassa & $1100 \mathrm{ka}$ & $\mathrm{P}$ & C & Magnetostratigraphy, mammal & Palombo et al., 2010 \\
\hline
\end{tabular}




\begin{tabular}{|c|c|c|c|c|c|c|}
\hline & & & & & biostratigraphy & \\
\hline 66 & $\begin{array}{l}\text { Torre Mucchia } \\
\text { (Ortona) }\end{array}$ & MIS 17 & $P$ & M & Magnetostratigraphy & Pieruccini et al., 2016 \\
\hline 67 & Carsoli & ca. 530 & $\mathrm{M}$ & $\mathrm{C}$ & Ar/Ar dating & Sadori et al., 2010 \\
\hline 68 & Peperino (Rome) & $513 \pm 3 \mathrm{ka}$ & $\mathrm{M}$ & $\mathrm{C}$ & Ar/Ar dating & Follieri, 2010; Marra et al., 2014 \\
\hline 69 & Riano & $450-350 ? \mathrm{ka}$ & $\mathrm{M}$ & C & Mammal biostratigraphy & Follieri, 1958, 1962 \\
\hline 70 & Valle Ricca & 2100-1800 ka & $P$ & $\mathrm{M}$ & $\begin{array}{l}\text { Magnetostratigraphy, } \\
\text { biostratigraphy }\end{array}$ & $\begin{array}{l}\text { Urban et al., 1983; Arias et al., } \\
1990\end{array}$ \\
\hline 71 & $\begin{array}{l}\text { Valle di } \\
\text { Castiglione }\end{array}$ & $250-0 \mathrm{ka}$ & $\mathrm{P}$ & $\mathrm{C}$ & $\begin{array}{l}\text { Varve counting, astronomic } \\
\text { calibration }\end{array}$ & $\begin{array}{l}\text { Follieri et al., 1988, 1989; Di Rita et } \\
\text { al., } 2013\end{array}$ \\
\hline 72 & $\begin{array}{l}\text { Coste San } \\
\text { Giacomo }\end{array}$ & ca. 2100 ka & $\mathrm{P}$ & $\mathrm{C}$ & $\begin{array}{l}\text { Magnetostratigraphy, mammal } \\
\text { biostratigraphy }\end{array}$ & Bellucci et al., 2014 \\
\hline 73 & $\begin{array}{l}\text { Fontana } \\
\text { Ranuccio }\end{array}$ & MIS 23 & $\mathrm{P}$ & $\mathrm{C}$ & Magnetostratigraphy & Corrado and Magri, 2011 \\
\hline 74 & Ceprano & MIS 15-13 & $\mathrm{P}$ & $\mathrm{C}$ & Magnetostratigraphy & Manzi et al., 2010 \\
\hline 75 & $\begin{array}{l}\text { Isernia - La } \\
\text { Pineta }\end{array}$ & $900-700 \mathrm{ka}$ & $\mathrm{P}$ & $\mathrm{C}$ & Magnetostratigraphy, Ar/Ar dating & Lebreton, 2002 \\
\hline 76 & Sessano & MIS 14-13 & $\mathrm{P}$ & $\mathrm{C}$ & $\begin{array}{l}\text { Magnetostratigraphy, } \\
\text { Tephrochronology, Ar/Ar dating }\end{array}$ & Russo Ermolli et al., 2010a, 2015 \\
\hline 77 & Boiano & MIS 13-9 & $\mathrm{P}$ & $\mathrm{C}$ & Ar/Ar dating, tephrochronology & $\begin{array}{l}\text { Orain et al., 2013, 2015; Russo } \\
\text { Ermolli et al., } 2015\end{array}$ \\
\hline 78 & Saticula & ca. $1200 \mathrm{ka}$ & $\mathrm{P}$ & $\mathrm{C}$ & Mammal biostratigraphy & Russo Ermolli et al., 2010b \\
\hline 79 & Acerno & MIS 13-12 & $\mathrm{P}$ & $\mathrm{C}$ & tephra, Ar/Ar dating & $\begin{array}{l}\text { Munno et al., 2001; Russo Ermolli } \\
\text { et al., } 2015\end{array}$ \\
\hline 80 & $\begin{array}{l}\text { Lago Grande di } \\
\text { Monticchio }\end{array}$ & $130 \div 0$ & $\mathrm{P}$ & $\mathrm{C}$ & $\begin{array}{l}14 \mathrm{C} \text { dating, tephrochronology, } \\
\text { varve counting }\end{array}$ & $\begin{array}{l}\text { Allen et al., } 2000 ; \text { Allen and } \\
\text { Huntley, } 2009\end{array}$ \\
\hline 81 & Vallo di Diano & $650-450 \mathrm{ka}$ & $\mathrm{P}$ & $\mathrm{C}$ & tephra, $\mathrm{Ar} / \mathrm{Ar}$ dating & $\begin{array}{l}\text { Russo Ermolli, 1994; Russo Ermolli } \\
\text { et al., } 2015\end{array}$ \\
\hline 82 & Camerota & $1750-1600 ? \mathrm{ka}$ & $\mathrm{P}$ & $\mathrm{C}$ & Biostratigraphy & Brenac, 1984 \\
\hline 83 & Mercure & MIS 13 & $\mathrm{P}$ & $\mathrm{C}$ & Tephrochronology, Ar/Ar & Petrosino et al., 2014 \\
\hline 84 & San Lorenzo & $1200-1100 \mathrm{ka}$ & $\mathrm{P}$ & $\mathrm{C}$ & $\begin{array}{l}\text { Magnetostratigraphy, mammal } \\
\text { biostratigraphy }\end{array}$ & Sabato et al., 2005 \\
\hline 85 & $\begin{array}{l}\text { Montalbano } \\
\text { Jonico }\end{array}$ & $1250-900 \mathrm{ka}$ & $\mathrm{P}$ & $\mathrm{M}$ & $\begin{array}{l}\text { Ar/Ar dating, Oxygen isotope } \\
\text { stratigraphy }\end{array}$ & $\begin{array}{l}\text { Joannin et al., 2008; Bertini et al., } \\
2015\end{array}$ \\
\hline 86 & Semaforo-Vrica & 2460-2110 ka & $\mathrm{P}$ & $M$ & $\begin{array}{l}\text { Magnetostratigraphy, foraminifer } \\
\text { biostratigraphy, K/Ar dating }\end{array}$ & $\begin{array}{l}\text { Combourieu-Nebout and Vergnaud- } \\
\text { Grazzini, 1991; Combourieu- } \\
\text { Nebout, 1993; Klotz et al., } 2006\end{array}$ \\
\hline 87 & Santa Lucia & MIS 43-40 & $P$ & $\mathrm{M}$ & $\begin{array}{l}\text { Biostratigraphy, Oxygen isotope } \\
\text { stratigraphy }\end{array}$ & Joannin et al., 2007b \\
\hline
\end{tabular}




\begin{tabular}{|c|c|c|c|c|c|c|}
\hline 88 & Valle di Manche & MIS 20-18 & $\mathrm{P}$ & $\mathrm{M}$ & $\begin{array}{l}\text { Magnetostratigraphy, Oxygen } \\
\text { isotope stratigraphy, } \\
\text { Tephrochronology, Biostratigraphy, } \\
\text { Ar/Ar dating }\end{array}$ & Capraro et al., 2005 \\
\hline 89 & Ohrid & $500-0$ ka & $\mathrm{P}$ & $\mathrm{C}$ & 14C, tephra, stratigraphy & $\begin{array}{l}\text { Wagner et al., 2009, 2014; Sadori } \\
\text { et al., } 2016\end{array}$ \\
\hline 90 & Ioannina & 450-0 ka & $P$ & $\mathrm{C}$ & Pollen biostratigraphy & $\begin{array}{l}\text { Tzedakis, 1994; Roucoux et al., } \\
2008\end{array}$ \\
\hline 91 & Acheloos Delta & $5-3 \mathrm{ka}$ & $P$ & $\mathrm{M}$ & $14 \mathrm{C}$ dating & Fouache et al., 2005 \\
\hline 92 & Zakynthos & 2000-1800 ka & $P$ & $\mathrm{M}$ & $\begin{array}{l}\text { Magnetostratigraphy, oxygen } \\
\text { isotope stratigraphy }\end{array}$ & Subally et al., 1999 \\
\hline 93 & Gulf of Corinth & $1800-600$ ka & $\mathrm{P}$ & $\mathrm{M}$ & $\begin{array}{l}\text { Pollen biostratigraphy, regional } \\
\text { stratigraphical correlations }\end{array}$ & Rohais et al., 2007 \\
\hline 94 & Kopais & $500-2$ ka & $\mathrm{P}$ & $\mathrm{C}$ & Pollen biostratigraphy & Tzedakis, 1999; Okuda et al., 2001 \\
\hline 95 & $\begin{array}{l}\text { Megalopolis } \\
\text { Basin }\end{array}$ & $650-300$ ka & $\mathrm{P}$ & $\mathrm{C}$ & $\begin{array}{l}\text { Magnetostratigraphy, } \\
\text { palaeontology }\end{array}$ & Okuda et al., 2002 \\
\hline 96 & Kallithea & Calabrian & $\mathrm{M}$ & $\mathrm{C}$ & Mollusc biostratigaphy & $\begin{array}{l}\text { Mai and Velitzelos, } 2007 \text {; } \\
\text { Velitzelos et al., } 2014\end{array}$ \\
\hline 97 & Kolymbia Bay & 500 ka & $\mathrm{M}$ & $\mathrm{M}$ & Magnetostratigraphy & Boyd, 2009 \\
\hline 98 & Tsampika Bay & MIS 42-1 & $\mathrm{P}$ & $\mathrm{M}$ & $\begin{array}{l}\text { Magnetostratigraphy, Oxygen } \\
\text { isotope stratigraphy }\end{array}$ & Joannin et al., 2007a \\
\hline 99 & Tenaghi Philippon & $1350-0 \mathrm{ka}$ & $P$ & $\mathrm{C}$ & Pollen-orbital tuning & $\begin{array}{l}\text { Wijmstra, 1969; Wijmstra and Smit, } \\
\text { 1976; Van der Wiel and Wijmstra, } \\
\text { 1987a,b; Tzedakis et al., 2006; } \\
\text { Fletcher et al., 2013; Pross et al., } \\
2015\end{array}$ \\
\hline 100 & DSDP Site 380 & $6000-0 \mathrm{ka}$ & $\mathrm{P}$ & $\mathrm{M}$ & Nannoplankton & $\begin{array}{l}\text { Biltekin, 2010; Popescu et al., } \\
\text { 2010; Biltekin et al., } 2015\end{array}$ \\
\hline
\end{tabular}




\section{Highlights:}

- The Quaternary disappearance of tree taxa in S Europe appears distributed over time

- Simple North to South and/or West to East trend in extirpations cannot be recognized

- Some taxa disappeared from wide areas of S Europe in the Lateglacial and Holocene 